Historic, archived document

Do not assume content reflects current scientific knowledge, policies, or practices. 



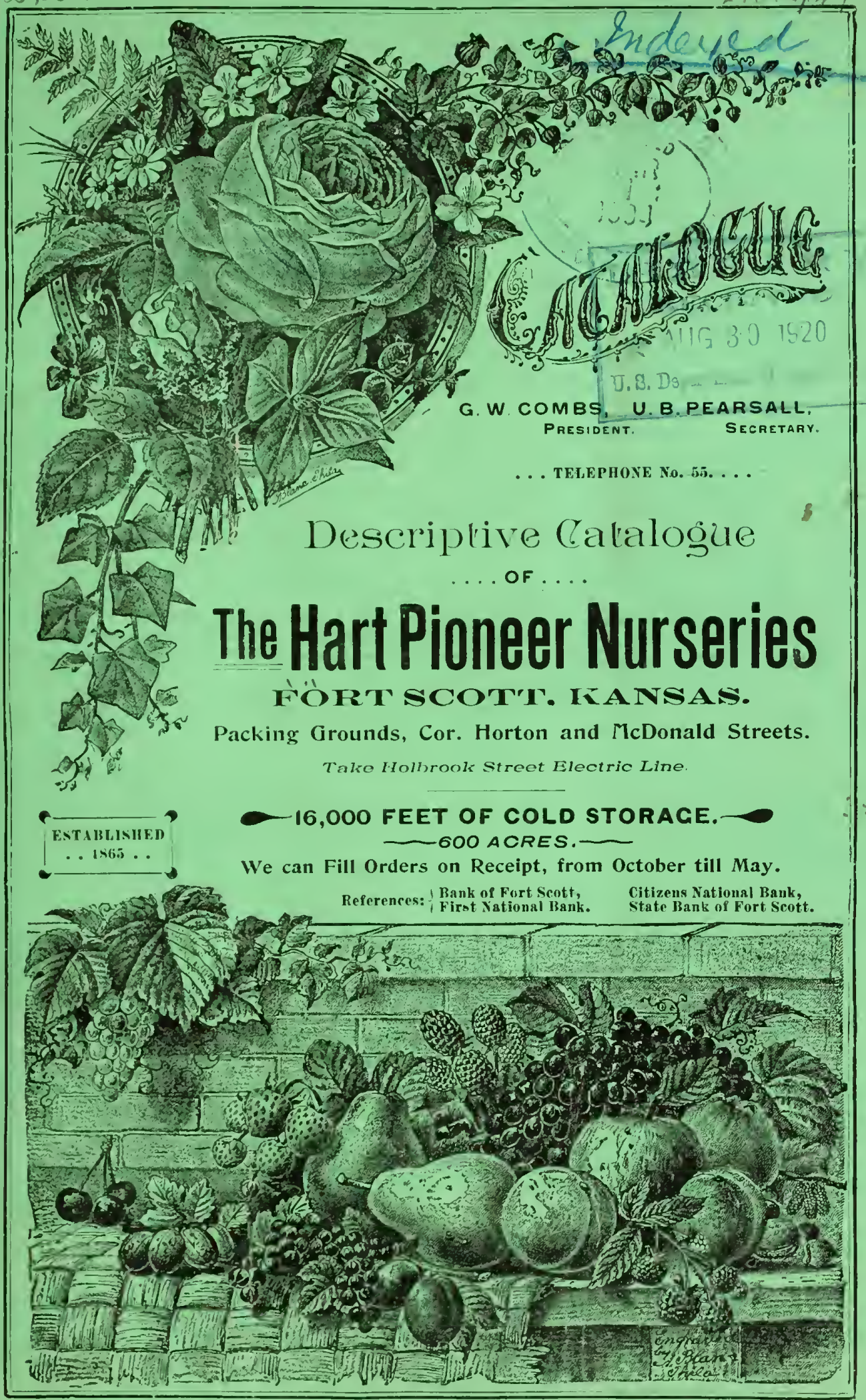




\section{TO OUR PHTRONS.}

T'N presenting our Descriptive Catalogue for your consideration, we wish to remind you that our stock is all young, smooth, thrifty and well grown on new upland, and our prices are based on the actual cost of growing.

We take this occasion to thank our customers for their very liberal patronage the past season, and hope to merit a contınuance of the same. We respectfully solicit al trial :order from those with whom we have not dealt. We call your especial attention to our large stock of Peach Trees. Grape Vines and Roses, all of our own growing and equally as good as those of Eastern firms. You can save money and get your stock fresh by buying from us.

\section{OUR PACKING GROUNDS.}

Our Packing Grounds are in the center of the city of Fort Scott, on which we have the most extensive stone cellars and Storage Packing Houses in the West. A complete system of water works affords an ample and easy. supply of water to all parts of the grounds. The street oars run near our doors. Telephone connects us with our Nurseries and all parts of the city.

\section{PROMPTNESS AND DISPATCH.}

We realize the neccessity of this; and we make a specialty of filling! orders promptly. If you need anything in a hurry, try us.

\section{RAILROAD FACILITIES.}

Fort Scott has a system of railroads reaching out TEN different directions and tapping every other important road in the country, and the Adams, American and Pacific Express Companies thereby giving us shipping facilities rarely found for cheap rates of freight and rapid transit by the most direct route to destination.

Our regular shipping season commences about October 10, and our facilities are such that we can ship nearly every day from that time until April 20. We box and pack trees in moss, so that they go the longest distances with perfect safety.

\section{MPORTANT.}

Plain shipping directions should accompany orders. In the absence of these we will forward to the best of our judgment, but in no case do we assume responsibility after consignment to purohaser. When loss occurs by detention en route, claim should be made on carriers immediately.

\section{OUR ASSORTMENT.}

Our assortment of Fruit Trees for Private or Commercial Orchard Planting in both new and old varieties, Ornamentals, Deciduous and Evergreens for Parks, Street and Home planting, with Shrubs, Roses, Vines, etc., can not be surpassed anywhere in this country.

\section{TEST ORCHARDS.}

Our orchards in bearing and the testing of all new fruits as quickly as present methods admit, besides planting in experimental orchards as well, enable us to determine the merits of new varieties ahead of usual time; discarding such as are deemed unworthy of further dissemination, and propagating more extensively such as have merit enough to warrant continuance. Thus we are enabled to fill orders for inexperienced planters better than they could select of their own accord. However, we will say that as a rule, please yourselt. It is far better in making a selection to first consult some one who has:a planting in the viciinity. Ascertain if there are varieties that have done remarkably well with him, and go no further in search of varieties, unless you are able to experiment with other varieties.

Direct all Letters to

\section{THE H.ART PIONEER NURSERIES,}




\section{PREF ACH.}

N PRISENTING this Catalogue it is safe to assert that the Nursery business has kept abreast with all the other great cuterprises of the coltutry. A host of new varicties of the varions kinds of fruits have been bronght to the front, sone of which have bccu classcd with those vcry worthy of cultivation, while many of the others have fallcu back into the grave of dcspair, being classed as worthless and nevcr again to be resurrected. The past few years have developed the fact that the fruit business and the growing of fruits for the narket will be in the frout rank of the great busincss cntcrpriscs of the West. This is evidenced by the large anount of fruit trees that are being planted aud the interest being manifested in the selection of varieties; the care taken in the growing of trees and in the destroying of the destructive insects that are so fatal to the growing and developing of sonnd, lealthy, wcll developed fruts.

The rapid increase in the mannfactureand in the dcmand for spraying machines is another strong evidence of the intercst being taken in the growiug and naturing of good sonud fruit for the market. Int the nurserymen have not only to consult the wants of those who are plating large commercial orchards for the money to be dcrived thcrcfom, but his desire is also to reach the amateur and moderate planter, whose object is to grow a family orchard of the varieties best suited for dessert and home consumption, so that a succession of the best fruits from the earliest to the latest ripeniug nuay be olntained, and this, in the prepari::g of this catalogne the greatest pains have been taken to make the descriptions and the scason of ripening as acurate and intelligible as possible,

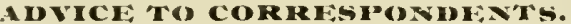

Please read before making out your or der.

Persons scuding in orlers slionld observe as far as possible the following regulations:

First. Send in your order as early as possible so that there may be no delay when the proper time for shipment artives. All orders will receive prompt alicntion.

Second. All orkers shonld he written out on an order sicet and not mixed up in the body of the letter; this will save nuch trouble and at the same time prevent mistakes.

Third. In ordcring fruit trees state whether staudard or Dwarf trees are wanted, also the age, size and number wanted.

Fourth. When particular varieties are ordered, state whethcr and to what extent other varieties nuy he substituted, in case the order cannot be filled to the letter as happens occasionally in all nurseries, when no instructions of this kind accompanies the orch, the best judgment will be exercised iu filling the order so as to render satisfaction to the purchascr.

Fifth. It is reciuested that explicit directions for marking and shipping stock accompany the order, when sucil directions are not given, it will be slipped the chcapest and most direct ronte by freight unless it is dec-ned safcst and best to ship by express, aul in all cases tive slipmcnt will be at the risk of the purchaser, and if delay or loss occurs in transit the forwarders alone must be held responsiblc.

Sixth. All orders from nuknown correspondents must be acconpanied with a draft, or postoffice or express money order for the anount, if neither can be olntained euclose currency in registercd letter.

Seveuth. Customers are requested to send notice at once of an error that may be committed in flling their orcler, so that it may be rectified and explained.

\section{A R'TICI,FS WY MAII.}

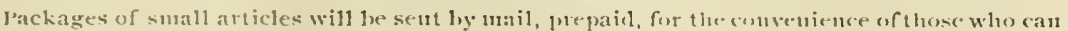

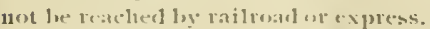

THI: SHIT'ING ALASOX.

"Thete can lee no defruite tine specified for leginuing to ship stock either in the spring or in the autumu, that is regulated by the opcuiug of the spring early or late and by the i ipeniug up of 
the stock in the fall, as the season for planting is not regulated so much by any particular month or day, nor by the state of vegetation where the planting is to be done, but more particularly bythe condition of the trees to be planted. It is therefore the more earnestly requested that orders be sent in early and the stock will be shipped or delivered at the proper season in good condition.

\section{GUARANTEE OF GENUINENESS.}

While the greatest diligence and care to have all trees, etc., true to label will be exercised, mistakes may occur and in such cases irpon proper proof the trees, etc., willibe replaced free of charge or the amount of money paid for them will be refunded, and it is mutually understood and agreed to between the purchaser and the seller that the guarantee of genuineness shall in no case make the nurserymen who sold the trecs, etc., liable for any sum greater than that originally paid for the trees, etc., that proved untrue, nor for damage.

\section{REMARKS.}

In looking over the index of an old edition of Downing's Fruits and Fruit 'Trees of America, there appears the names of about 3,450 Applcs, 2,770 Pears, 880 Plums, 500 Peaches, 550 Cherries, 600 Grapes, 450 Strawberries, etc. This includes the syuouyms which would doubtless reduce the rea1 number of the different kinds to one-half the above amount, but when we cousider the many new varieties that have been added to the 1 ist in the past forty years, and compare the number of varieties now in cultivation, we will readily see how few of all this number have proved beneficial or profitable to the commercial and also the sinall orchardist. Thirty to forty varieties of Apples would probably cover the amount regarded as profitable for commercial purposes, and eighty to one hundred varieties for the ordinary planter, aud only a few of theseare generally selected for a well arranged orchard for either commercial or family purposes, and it would be in about the same or a less proportion with the other kinds of fruits. Therefore, in arranging this catalogue only such varieties are given a place as are now in general cultivation (some of which will succeed well only in certain localities), and also such new varieties as are generally approved, so that by a judicious selection from this list a model orchard may be obtaiued.

\section{HINTS ON TRANSPLANTING, ETC.}

The failurevin having trees, etc., to grow or even to grow off vigorously after being translanted is too often caused by too much exposure of the roots to the atmosphere, or a lack of sufficient moisture about the roots while out of the ground, yet a healthy tree may be taken fresh fron the ground where it grew and kept in the very best condition, and when properly transplated will die from some unknown cause. A feeble or poor growth is usually caused by not having the ground in proper condition at the tiue of transplanting a ud a lack of proper after-cultivation.

The natural place for a fish is in the water, so the natural place for the roots of trees and plants is in the ground. The moment a fish is taken from the water it begins to sicken and die, so the moment the roots of trees, etc., are exposed to the atmosphere they begiu to loose their vi. tality, therefore let it be remembercd that too unncli care cannot be taken to protect tlie life and vitality of trees and plants while ont of the ground.

\section{SOIL, I'TS PREPARATION, EXPOSURE, FTC.}

Any soil that will grow good crops of corn and small grain will answer for fruit trees, etc. Eastern and northern exposures are usually considered the best, but perhaps more depends on the quality of the soil and its preparation aud after-cultivation than in the exposure. If the gronnd is naturally wet, spouty and cold, artificial drainiug is necessary beforc planting. Any ground should be well prepared by twice plowing, using the subsoil plow after the common one at the second plowing, and stiring the ground twenty inches or inore deep, the deeper the better; this is not only for trees but small fruits as well. On good rich soil manuring will be nunecessary, but on thin or poor soil, fertilizers, such as well decomposed manure or compost, slionld be applied freely. Never grow small grain in the orchard, but always sone crop that will require tliorongli cultivation, and the rows of trees should be kept cultivated at least until the montli of August.

Transplanting. When the trees are received, open the bundles and hcel in so that mellowearth will cone in contact witl all the roots. It may be necessary to apply water to luoisten the soil; before planting, the ends of all bruised and brokcu roots inust be cut sloping from the under side. If the soil is properly prepared the holes nced not be dug nuch larger than to receive the roots in their original position. In plantiug in sol in yard or lawu the bole slould be dug four to six feet 
in dianreter and a little deeper than is necessary to set the tree, always nsing good tucllow soil in filling in, pressing the ground well about the roots, and $i n$ such a manuer as to leave them in their natural positiou as much as possible. Water freely used in planting helps to settle the earth about the roots and a 1 ulching as soon as the tree is planted three or four inches thick and four to six feet in dianeter should be applied, but the earth should be well pressed about the tree before applying the mulchiug.

\section{DEFTH TO PYANT.}

About the only correct guide that can be given in regard to the depth to be planted is that when the ground is well pressed about the tree or plant it will be as decp or a little deeper than it stoon in the nursery; aud iu this it is well to bear in mind that the roots of some trees such as the standard Pear, strike their roots deep, and require a deep hole even to plant thein as deep as they were in the nursery. Dwarf trees slould be planted so that all the stock on which they are worked will be under the ground.

\section{PRUNING.}

Cut back oue-third to one-half of the last season's growth, a ud oue year old Peach to almost a bare stoci. and headed back to the desired height, for forming the top; the buds on the body of the tree will make a better growth and form a better top than if the side branches are left on. It is not advisable to do any of this pruning until just befo a the buds start in the spring. Remove the labels before the trees begiu to grow.

\section{WINTERING TRFES WHEN PFOCURFI IN THE, FALI.}

Procuring trees in the Autumn for early spring planting, is recommended when the purchaser is not prepared to plant in the fall or prefers spring setting, or where the winters are too severe to set out young trees and plants in the fall; the greatest advantages derived in doing so are that when the roots have been cut or pruned, it will be found upon taking then up in the spring that a callus has been formed rcady for the producing of new rootlets, and the trees being planted without 11 uch exposure as soon as the frost is out of the ground; will become thoroughly established the first season, and should make twice the growth of late planted trees; and the labor of planting is then doue before the rush of the spring work sets in. To insure success select a dry spot of ground where water will not stand during winter, and no grass or litter that will invite mice. Dig a trench from three to four feet wide according to the amount of trees to be healed in, and deep enough to adnit oue layer of roots and sloping enough to let the trees lay at an angle of abont thirty degrees, throwing the earth on the back part of the trenches so as to make a more perfect slope on which to lay dowin the trees. Put in one layer of trees, placing the roots as close together as can conveniently be done, cover with well pulvcrized soil well up ou the bodies and as carefully worked in about the roots as if they were being planted; then add another layer of trces overlaping the first and continue as at first until all are healed iu, throwing the ground well up around the trench, and where the winters are very severe it is advisable to cover the tree entirely up with earth. Evergreen boughs or coarse straw or corn fodder can be placed over the tops, but not thick enough to admit of a harbor for mice. The roots should be pruned before layiug thenedown in the fall.

\section{TREATIENT OF TREES, ETC., TMAT HAVE HEEN FROZEN IN THE PACKAGES OR RECFIVED DURING FROSTY WTATHYR.}

Put then unopened in a cellar or some othet cool protected place free from frost, or cover theu up lieavily and entirely with earth nntil they are fully thawed out, when they can be unpacked and planted or placed in trenches until convenient to plant; treated in this way they will not be injured by the freeziug.

SUITABI, IOS'TANCHE FOR I'I,ANTING.

Apples, standard $\ldots \ldots \ldots \ldots \ldots \ldots . . . . .5$ to 40 feet Apples, Dwarf...................6 to 8 "

Pears, Standard.................... 16 to 1 s

Pears, Dwarf................... 10

Peachcs................... .16 to 18

Nectarines and Apricots.......... 16 to 18

Cherries, swcct...................16 to 20

Cherries, Sour....................

Plums ....................... If to 20

Quinces ...................... 10 to $] 2$
Grapes...................... \& to 10 feet

Currants........................ 3 to 4 "s

Goosebcrries.................... 3 to 4 "

Raspbcries, Rc1 ............... 4 to 5

Raspbcrics, Black ............. 5 to 6 Blackberries................... 5 to 7

Strawberries, kows............. 1 by $3 \frac{1}{2}$ "

Strawberries in Beds ..............1 1 by $1 \frac{1}{2}$ "

Asparagus in Beds .............. 1 by $1 \frac{1}{2}$ " 


\section{NUMHEIR OF TREES AND PLANTS ON AN ACRE A'T VARIOUS IIG- TANCES.}

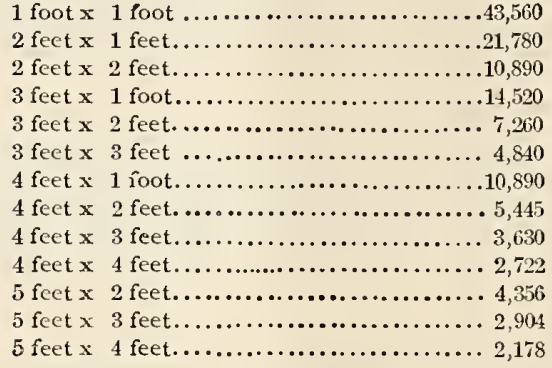

5 feet $x 5$ feet $\ldots \ldots \ldots \ldots \ldots \ldots \ldots \ldots \ldots, 7,742$

6 feet $x \quad 6$ feet........................... 1,210

8 feet $x \quad 8$ feet........................6. 680

10 feet $x 10$ feet.........................

12 feet $x 12$ feet....................... 30.2

15 feet $x 15$ feet....................... 19

16 feet $\times 16$ feet.................... 170

18 feet $x 18$ feet....................... 131

20 feet $x 20$ feet........................ $10 \mathrm{~s}$

25 feet $x 25$ feet..................... 69

30 feet $x 30$ feet........................ 4t

33 feet $x 20$ feet....................... 66

The number of plants required for an acre, at any given distance apart, may be ascertained by dividing the number of square feet in an acre $(43,560)$ by the number of square feet give to each plant, whieh is obtained by multiplying the distance between rows by the distance between the plants. Thus, Strawberries plauted three feet by oue foot, gives eaeh plant three square feet, or 14,520 plants to the acre.

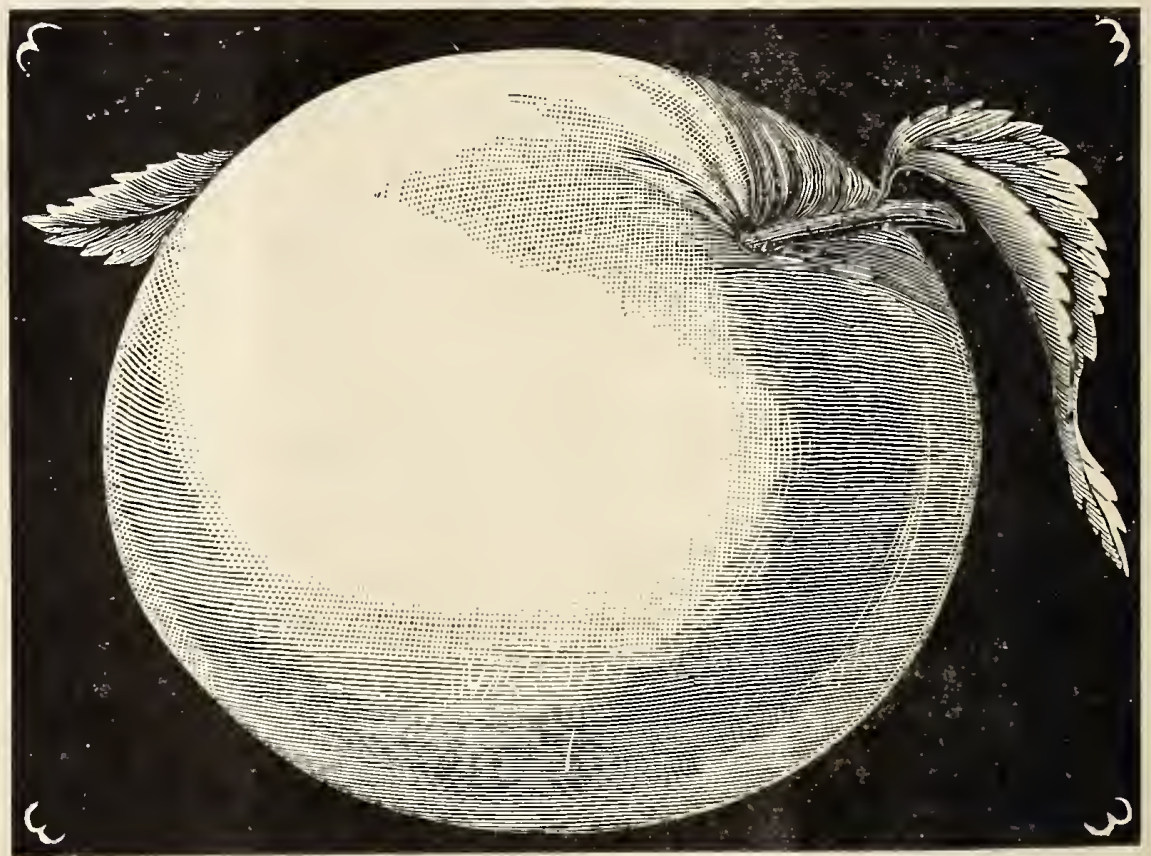




\section{FRUIT DEPARTMENT.}

Xotr 1. Those sorts with a star prefixed are of recent origin or introduction and nsually classed as _ew, Ironclad, and Russian varieties.

Note 2. Inabit of growth is indicated by .Yod., Fer, Fig., Slorc, at end of description, meaning Moderate, Free, Vigorous, or Slow growers.

ХотЕ 3. The scason of ripening given aftet habit of growtl cubraces that portion of the country between parallels thirty-niue and forty. This takes in Dayton, Ohio; Indianapolis, Indiana; Springfield, Illinois; Kansas City, Missouri, and Topeka, Kansas. The season of ripening will be earlier or later in proceeding South or Xorth.

Note 4. Directions for spraying will be found in the last page's of this catalogue.

\section{APPLES.}

The Apple stands at the hcad of the list in importance lotı for general culture and for commercial purposes. Its season mulike that of otler fruits extend nearly or quite througli the year. By planting judicious selcctions of Sumucr, Autumn, and Winter sorts, a constant succession can be obtained of this indispensable fruit for family use. Past experience has proven that no other farm crop will producc as much income per acrc as an Apple orchard. As it takes from five to seven years for an Apple orchard to come into bearing some persons hesitate to plant, regarding the time too long to wait, but when we look back a period of a few years we observe how yuickly time has passed, and so it will be in the future as in the past, and one thing is certain if we do not plant we will never obtain. To enconrage those who are hesitating as regards the profits obtained from the growing of Apples for the market, a statement from Messrs. Wellhouse \& son, of Fairmont, I.eavenwort1 County, Kansas, dated July 13, 1592, is here given as follows:

"GEXTLEMEX:- Yours of July $9 \mathrm{th}$, is at hand and in reply have to say that onr bearing orchards were planted in 1876,187 s and 1879 and covers 437 acres and commenced bearing in 1850 , and up to this time from twelve crops we have gathered and sold 300,565 bushels, and after paying for gathering, packing and marketing, thesc crops have netted ns a little over $\$ \$ 2,000.00$." Now this indicates what perseverance and determination will do, and to show the confidence that these mammoth fruit growers have in this lucrative lunsiness they further add: "We have planted eight lundred acres in the last three years and will plant three luudred actes a year from next spring." Observe that the net profits in twelve years was a little over eighty-two thousand dollars and this begins only four years after the first planting.

Some persons may say that there are so many orchards being planted that the demand wili not equal the supply and thus hesitate to plant. This las been the cry for the past thitty or forty years, and it is the commercial fruit grower to-day that is taking in the money far exceeding that obtained by the ordinary farmer. This is a large conntry and it is seldom that there is a full crop of fruit in all the states and territories the same year, and the evaporating of fruits has become such an immense busincss that it may be doubtcd if orcharding will ever in any season he less than higlly remuncrative.

If Apples are planted at the rate of fifty trees per acre, rows of Peach trees can be planted between the Apples, which, growing more quickly than the Apple trees, soon protect them from the wind, and thus are a great bencfit to them. After cight or ten ycars of productiveness, as the space is needed for Apples, the Peacli trees nua he removed, leaving the orchard better for the protection, and at the same time laving yielded the planter a large return for his trouble. 


\section{SUMMER APPLES.}

NOTICE.-Those with * are of recent origin or introductiou.

Imerican Summer Pearmain. Medium, oblong; striped and dotted with red; tender, juicy and rich; good bearer; mod. August.

Astrachan Red. Irarge, roundish, nearly covered with deep crimson, overspread with thick bloon; juicy, rich and beautiful; a good bearer; free. July.

Benoni. Medium, roundish; pale yellow shaded with crimson; juicy, tender, sub-acid. August.

Carolina Red June. (Red June). Medium size, red, flesh white, tender, juicy, sub-acid; an abundant bearer. Last of June.

Chenango Strawberry. (Sherwood's Favorite). Fruit medium size, oblong, indistinctly ribbed; skin whitish, splashed and mottled with light and dark crimson; flesh white; tender, juicy, with a mild sub-acid flavor. A pleasant fruit, esteemed for the table, and so handsome as to make it a quick selling market variety. Tree vigorous and a good bearer. Aug. and Sept.

Cooper's Early White. Very large, roundish, pale yellow with faint blush; flesh white, crisp, sprightly; a Western apple; vig. First of August.

Duchess of 0ldenburg. Russian, medium to large size; skin yellow, streaked with red and somewhat blushed sometimes with a faint blue bloom; flesh juicy and good, with a rich sub-acid flavor; productive; slow. August.

Farly lIarvest. Medium to large, roundish, bright straw color; flesh white, tender, juicy, crisp, with rich sub-acid flavor; tree moderately vigorous and productive; one of the best. First of July.

Early Strawberry. Medium, roundish, handsomely striped with red; excellent, productive; morl. First of July.

Farly Ripe. A large yellow apple, ripening with or immediately after the Early Harvest; a popnlar market fruit; free. First of July.

Golden Sweet. I arge, pale yellow, very sweet and good; good bearer; free. August.

Jefferis. Rather large, roundish, yellow skin striped with red; very rich, tender and juicy. This very beautiful variety is unsurpassed for dessert. Free. July to September.

Keswick Codlin. I,arge, tender, juicy; excellent for cooking; productive and early in bearing; free. July and August.

Plumb's cider. An early bearer and productive; fruit medium, roundish, slightly conical; skin greenish yellow, shaded and rather obscurely striped and splashed with dull red; flesh whitish, tender, juicy and mild, sub-acid; vig. A ugust and September.

Red Bietigheimer. A rare and valuable German variety; fruit large to very large; roundish, inclining to conical; skin pale cream colored ground, mostly covered with a purplish crimson; flesh white, firm, sub-acid, with a brisk pleasant flavor; tree a free grower and abundant bearer. This is one of the bandsomest apples, and worthy of extensive cultivation; vig. August and September.

Sweet June, or lligh Top Sweet. An excellent early sweet apple; pale greenish yellow, medium size, round; fine for table and cooking, perfectly tender; mod. 25th of June to middle of July.

Sweet Bough. Large, pale greenish yellow, tender and sweet; good bearer; mod. July:

Summer Queen. Medium to large, yellow streaked with red; flesh tender with an acid aromatic flavor; mod. August.

Sops of Wine. Medium size, red; flesh white, often stained; inild and pleasant; productive; free. July and August.

$\checkmark$ Tetofsky. (Russian). The tree is an upright spreading grower, forming an open head; comes into bearing extremely early and bears every year; hardy as a crab, fruit good size, nearly round; yellow, beautifully striped with red; flesh white, juicy, pleasant, acid, aromatic; very slow in 11 ursery. July.

*Yellow Transparent. (Russisn Transparent, Grand Sultan). Of Russian origin; imported by the Department of Agriculture in 1870; ripening with Early Harvest, while the fruit will keep fully ten days after ripening, making it peculiarly adapted for early shipping. Fruit pale yellow, roundish, oblate; mediun size and good quality; skin clear white at first, becoming a beautiful yellow when fully ripe; slow. 


\section{AUTUMN $\triangle$ PPLES.}

tlexander. (Fimperor Russia). Large, decp red or crinson; flesh ycllowish white, crisp, tender, with pleasant flavor; very hardy; mod. Octobcr.

Autumn Strawbery. Medium, streaked; tender, juicy, fine; productive; desirable; free. August and September.

Bailey's Sweet. Fruit large, round, mottled and striped deep red; flesll yellow and tender, with a mild, rieli sweet flavor; slow. Scptember.

Dominie. (Well's linglish Red Streak). Mcdiun, skin grconish yellow; flesh very tender and pleasant; tree vigorous and prolific. October to Decentrer.

Fameuse. (Snow Applc). Mcdium size, roundish, oblate; whitish ground, striped with deep red; flesh very white, juicy and pleasant. Octoher and fovember.

Fall queen. (Buckingham). I arge to very large, oblate, greenish yellow striped with dull rea. tree productive and hardy; fruit very tender, jioicy and excellent; free. September and October.

Fall Wine. Medinu, dark red, flesln whitc and unexcelled in quality. October.

Fall Winesap. Origin unknown; trec a frce clean grower, moderately spreading, somewhat drooping as the tree acquires age; productive and an early bearer; fruit medium, roundish, sometimes slightly conical; yellowish grcen, with considerable blusl in the sun; flesh white, fine grained, tender, juicy, sub-acid, good; vig. October to December.

Flory's Bellfown. (Flory, Shcep Shire). Origin, Montgomery County, Oliio; tree upriglit grower; frnit medium, roundish, conical; ricl golden yellow, with small patches of russet and miunte raised russct dots; flcsli yellowisl1, tcnder, moderately juicy, snb-acid; good; vig. September and October.

Inas. Cros Pommier). Medium to large, slightly conical and somewhat ribbed; pale greenish yellow, shaded and striped with red; flesh fnc white, sometincs staincd, tender, juicy, sub. acid, good; bcars early and abundantly; vig. September and october.

llawley. Frnit largc, roundish, oblatc, conical; skin finc yellow, somewhat waxen or oily, and considerably dotted; flesh whitish, vcry tender, juicy, rich, mild, sub-acid; vig. September.

llay's Wine. (Penua. Red streak). Large, form angular, nearly round, a little flattened at ends; skin smooth, decp red, over a yellow ground; flesh yellow white, juicy and crisp; vinous, rich, and pleasant flavor; very good. September and october.

Jowell or Orange. Large, roundish, slightly conical; green, becoming rich yellow; surface oily; flesh yellowish white, sub-acid, excellent; good bearer; free. September.

Maiden"s Blusl. Rather largc, oblate, smooth, regular, with a fine evenly shaded red cheek or hlush on a clear, pale yellow ground; flesh white, tender, sprightly, with a pleasant sub-acid flavor; hears large crops; free. August and September.

Motller. Fruit medium, form roundish, slightly conical; color yellow, alınost entirely overspread with light, clear, rich red, splashed and marked with many deeper shades, many minute light dots; flcslı tender, juicy; rich, aromatic, sub-acid; best quality; tree slow grower. ' Sept.

Munson's swept. I,arge, pale yellow with red cheek; tender, rich and good; fine bearer; vigorons. September.

Porter. Rather large, regular, oblong, tapering to the eye; skin bright yellow, sometimes a dull blush in the sun; flesh tender, rich, sub-acid, flavor fine; productive; slow. September.

Mambo. Mediun, yellowish, strcaked with dull red and somewhat dotted; mild, tender an 1 good; productive and vigorous. September to November.

Smokelouse. English Vandevere). Large, yellow shaded; flesh yellowish; sub-acíd flavor; t-ae productive and moderately vigorous. October and November.

Wealthy. An apple of fine appearance and quality, an early and profuse bearer; a good mar ket apple of its season; tree hardy; its chief fanlt is killing itself by its early and excessiv bearing ; in size and bcauty it equals daldwin, and is a better dessert apple.

Niter's Red. Large, round, whitish and striped, vcry beautiful and excelleut, sub-acid; tree vi=orous, hardy, productive, requires dry soil; of great value north. September and October.

Yellow Bellflower. Largc, yellow, with a red blush; very tender, jnicy, sub-acik moderate grower and bearer. October to December. 


\section{WINTER APPLES.}

Irkansas Black. Origin, Bentonville, Arkansas; the tree is a beautiful upright grower, young wood very dark; fruit medium to large; fine flavor; beautiful dark color, almost blaek; flesh yellowish, slightly sub-aeid, erisp; one of the best cooking apples; vig. January to July.

Arkansas Beauty. Size, large; eolor, a beautiful light crimson in the shade, darker in the sun, with indistinet splashes and stripes over the whole surface of darker crimson; flesh fine grained, whitish color, tinged with red and yellow; flavor a rich sub-acid, quality very good; tree a good grower, an early and abundant bearer; season late; an excellent keeper.

Sallwin. Large, roundish, deep bright red; juiey, erisp, sub-aeid, good flavor; tree vigorous, upright and very produetive of fair handsome fruit. November and Deember.

Lau Davis. (New York Pippin). Fruit medium to large, roundish; skin yellowish, splashed and striped and almost covered with red; flesh white, tender, moderately juicy, sub-acid; an exeellent variety; tree very hardy, a free grower, coming into bearing early, and very productive; it blooms late in the spring, thereby often escaping late frosts; very popular in the West and Southwest. December to March.

(layton. Originated in Indiana; flesh yellow, breaking, sub-aeid; very good for both kitchein and market. January to Mareh.

('olfelt. A seedling from the Ben Davis, which the tree resembles in habit of growth; it possesses all the good qualities of the Ben Davis with none of the bad; a good grower and an abundant and regular bearer; the fruit hangs well on the tree, is a good handler, above mcdium si\%; beantifully striped and splashed with red on yellowish grouls?, is a much longer keeper and is far superior to the Ben Davis in flavor.

Welaware Red Winter. Medium to large, b.ight red, highly colosed; flesh fine grained, erisp, juicy, sub-aeid, excellent; remarkable for its long-keeping qualities; thought by some to be iclentical to the I,awyer.

Luglis! lasset. Fruit medium size, very regular, slightly eonical; pale greenislı yellow, about two-thirds covered with russet; flesh yellowish white, firm and crisp, with pleasant, slightly sub-acid flavor; free. December to April.

VGime's Golden. (Grime's Golden Pippin). An apple of the lighest quality, equal to the Newtown; medium to large size, yellow; tree hardy, vigorous and productive. November and December.

Whano. This apple was found by W. G. Gano in an old orchard planted by Jili Jacks near Par:ville, Platte County, Missouri, and it is said that the seedlings were carried from Boone County, Missouri. It was named on February 20, 1886, by the Missouri Valley Horticultura1 Soeiety, in honor of its President, W. G. Gano. In deseribing the fruit, I. A. Coodman, Secretary of the Missouri State Horticultural Society says: "The fruit is briglit red on yellow ground (nostripes), large, oblong, tapering to the eyc; surface smooth, polished; dots minute; basin shallow, sometimes deep; cye large, cavity deep, hrown in color; stem medium to long, core merlium, seeds large. Season, January to April." Tree very healthy, vigorous, hardy; having stood $32^{\circ}$ below zero without injury. A rapid grower; large and spreading in oreliard; fruit spurs numerous; shoots long, smooth, brown, with protuberances on the limbs like the Ben Davis; an early, annual and prolifie bearer. The tree much resembles the Beu Davis.

Gideon. A new variety, of extraordinary hardness, and of great value both for cooking and eating; originated in Minnesota with Peter M. Gideon, one of the most experienced fruit growers; "Iron Clad." October to March.

Gill's Beauty. Originated on the farm of Wyatt Coffelt, Benton Connty, Arkansas; a strong grower and good bearer, good flavor and very handsome. Deeember to February.

Grand Sultan. Flesh greenish white, tender, brisk, sub-acid; very good, excellent for eooking; tree a good grower and an enormous bearer. October to January.

Hateher's Seedling. Originated in Franklin, Tenn.; tree an upright, thrifty grower, producing good crops annually; jucy, mild, sub-aeid and rich; a late keeper and one of the most popular apples in Tennessee. January to March.

If untsman's Favorite. Originated in Johnson County, Missouri; very large, golden yellow, with bright red eheek; nearly sweet, fine flavor, very aromatic; one of the best and highest selling market apples; tree very healthy and moderately produetive; vig. November to January.

Hubbardston Nonsuch. Large, striped yellow and red, tender, juey and fine; strong, good bearer vifrous. Oetober to December. 
V

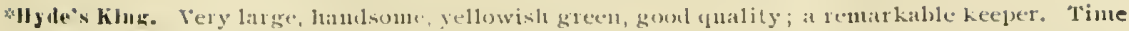
of keepiug, all the jcir round.

Flow B Blush. Medium in sire, roundish, conical, whitish, with red check; quality fine, tart; tree vigorons and hardy" on the prairies. November to January.

Jonuthan. Fruit uncdinn, roundish, shin yellow, nearly covered with dark or lively red; fine grained, very tunder aud fiucly flavored; mod. October to Iecember.

Keutucky Streak. (Bradford's best.) Fruit medium, conical, regular, dec; mottled red, stripes ol)scured and scarcely visible, dots scattered, large yellow, flesli yellow, tender.

King. (Tompkins County.) Iarge autl haudsone, stripel red and yellow, tree vigorous and productive. Noveuber aucl I)cceubcr.

Luwy.r. Origin, Ilatt Connty, Missouri; large, dark, bright rerl, ronudish, very showy; tree lardy; not productive; a late keeper. December to May.

wounfield. One of the imported Russian varieties; a free, upright grower, carly and abundant bearer, fruit uncdiun to large, yellowish green, thickly covered with red stripes; a decided blush ou the sumug side; rich, sprightly, sub-acicl. Decenber to March.

*oy. Originated in Howcll Commty, Missonri. Tle original tree commenced hearing at five years old, bearing regular aunul crops thereafter; fruit fully as large as the Ben Davis, and resembles Willow 'Twig in form and color; a beantiful red on yellow gronnd, deepening into a rich bronze or russet, with markings of minute black dots; small core, short stem, sprightly and plcasant flavor. December and Jannary.

Laly s Sivect. A handsone red apple, jncy, swcet and good; one of the best; mod. Nor: to Feb.

Inusingurg. Tree mpright, spreading and productive; fruit medium, roundish, oblate, yellow, largcly overspread witl grayish red, flesh firm, mild, sub-acid; good; valuable mainly for its long kceping qualities; vig. January to June.

little Romanite. (Gilpin Carthouse). Tree very hardy and productive; fruit of medium sixe, roundish, oblong, skin very smooth and handsome, streaked witl deep red and yellow; flesh yellow, firm, tich, becoming tender in spring; good; vig. Febrnary to Jung.

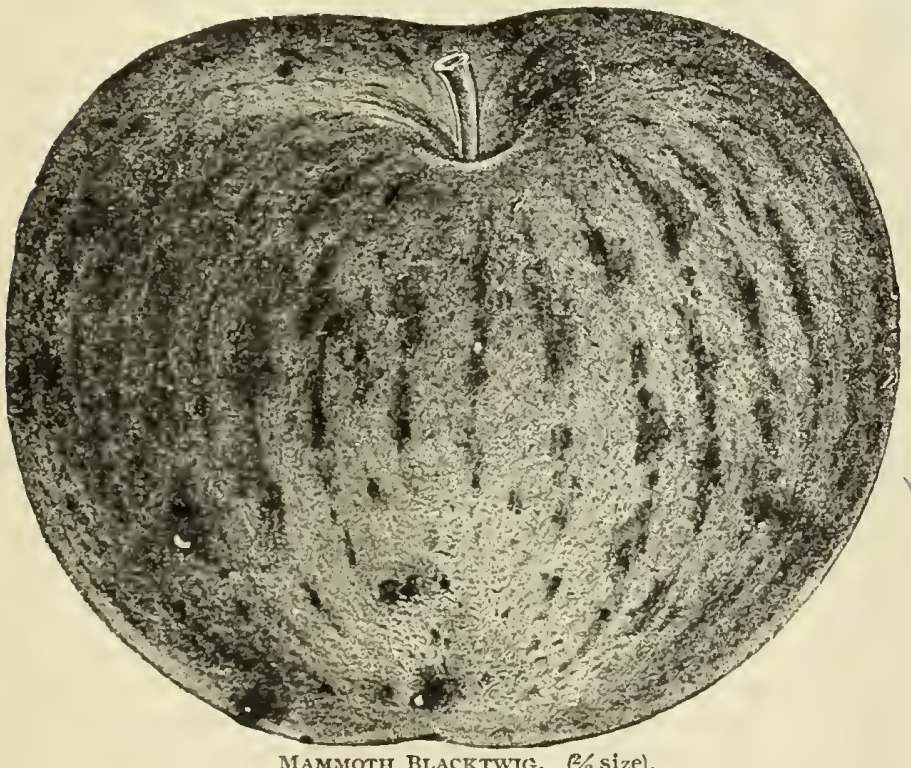

i. Iamunoth Biscktwig. Originated in Teusessce. Tree a fine 11 pright spreading grower, beats large crops and holds its fruit well; the fruit is inlly one-fourtl larger than the Wine Sap, which it resembles very $u \mathrm{uch}$ in color, flavor and keeping q 11 a $1 \mathrm{i}$. tics; vig. No$V$ vember to April.

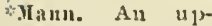
$\mathrm{riglit}$ grower, forming a ronnc liead, fruit mediit $\mathrm{m}$ to 1 a r g e, roundish oblate, skin deeprellow when fully ripe, with sometimes a shade of brownish red where exposed, flesh yellowish, juicy, mild, pleasant, sub-acid, good to very good; vig. A pril and May.

YycIntosh Red. Fruit above medinm, skin smooth, whitish yellow, covcred with dark, ricl, red, flesh white, firm, very tender, juicy, mild, sub-acid and of the bett quality, similar to liameuse but larger; vig. Novenuber to Jicbruary. 
Minkler. Frnit medium, roundish, oblate, slightly conical, pale greenish yellow, striped and splashed with two shades of red, flesh yellowish, compact, moderately juicy, mild, pleasant sub-acid; tree irregular grower; vig. January to April.

Missouri Pippin. Large, oblong, bright red, with numerous gray dots, very handsome and of fair quality, an early and very abundant bearer, and very profitable orchard fruit; vig. December to March.

Northern Spy. Fruit large, conical, flattened, skin greenish yellow, striped and shaded with light and dark pnrplish crimson and covered with a thin white bloom; flesh white, fine grained, tender, very juicy; a pleasant sub-acid. November and December.

Nickajack. (Southeru). Large, skin yellow, flesh tender, crisp and juicy, with rich sub-acid flavor; tree vigorous. November to April.

*Pewankee. Medium to large, roundish, somewhat flattened, bright yellow, streaked and spotted with dark red, flesh white, tender, juicy, sub-acid; a seedling from the Duchess of Oldenburg, and inherits its quality of extreme hardiness which makes it a most reliable kind in cold climates. December and January.

Peter the Great. A hardy aud valuable Russian variety. Tender, juicy and pleasant flavored.

Plumb's Cider. Large, oval, striped, tender, juicy, sub-acid; tree very hardy, vigorous and productive; of most value north.

Rawle's Janet. (Never Fail). Medium, roundish, ovate, greenish yellow, striped with red, crisp, rich and juicy; one of the best and longest keepers in the South and Southwest; mod. January to May.

Roman Stem. Fruit medium, whitish yellow, splashed with russet; flesh tender, juicy; rich, musky flavor; fine dessert apple; mod. November and December.

Rhode Island Greening. Large, greenish yellow, tendcr, juicy and rich, with rather an acid flavor; growing strong and spreading, and an abundant bearer, bilt drops prematurely at the West, and should be gathered early if planted at all. November and December.

Rome Beauty. (Gillett's Seedling). Large, yellow, striped with red, flesh juicy, crisp, sub-acid, tree moderate grower. October to December.

Rasset, Roxbury or Boston. Medium to large, greez ish or yellow russet, crisp, good sub-acid flavor, productive, very popular on account of its long keeping; vigorous. December to May.

Stark. Fruit large, roundish, skin greenish yellow, shaded and striped with light and dark red, nearly over the whole surface and thickly sprinkled with light brown dots; flesh yellowish, moderately juicy, mild sub-acid; free. December to February.

Seek-No-Further. (Westfield). Medium to large, slightly russetted with dull red stripes, tender, rich, spicy and fine; good bearer; mod. October to January.

8mith's Cider. A handsome fruit, large, oblong, somewhat flattened, skin yellow, changing to red; flesh tender, juicy, crisp, with pleasant sub-acid flavor; vig. November to February.

Stanard. Medium to large, yellow, splashed and striped with red; good; a very handsome apple and a good bearer; a valuable market sort. December to April.

Shannon. Large, yellow, juicy, pleasant, sharp sub-acid, core sma11; mod. January.

Shackleford. Originated in Clark County, Missouri. The tree is a vigorous grower aud a prolific bearer, better even than the Ben Davis; it flourishes on poor land with a clay sub-soil ; apples large, highly colored and finely flavored; choice cookers and good keepers. Season December to May.

Salome. Flesh whitish yellow, half fiue, tender, mild, slightly aromatic, very good Jauuary to May; its hardiness, long keeping, good quality, uniform size, retention of its flavor, quite late even into summer, will no doubt make it valuable for the West and Northwest. The tree is as hardy as any of the Siberian Crabs.

Shockley. (Southern). Medinm or below, whitish yellow, marked with red; flesh crisp, juicy; tree vigorous. Valuable for its late keeping.

Sutton Beauty. Fruit mediun to large, roundish, skin waxen yellow, striped with crimson; flesh whitish, tender, sub-acid, quality very good; tree a free, handsome grower and productive; flesh tender and juicy, good color and keeps late.

Tewksbury Winter Blush. A native of New Jersey. It is a handsome, fair fruit, with more flavor and juiciness than is usual in loug keeping apples; this may be kept until Angust without particular care, quite plump and souud; tree grows rapidly and straight, and the fruit hangs till late in the autumn. January to August. 
Tallman Sweetiug. Medium, pale yellow, firm, rich and very swect; the most valuable preserviug and baking apple; vig. October to Decelnbcr.

Vandevere. Medium, yellow ground; flesh light yellow, rich, sub-acid flavor; good grower and early bearer. November.

Wasener. Mediun to large, deep red in the sun, flesh firm, sub-acid and excellent, very productive, bears very young. October to Decenber.

White Plppin. I,arge, roundish, grecnish yellow, good quality, a fine orchard tree and very pro. ductive; an aunual bearer of handsome and good fruit. December to March.

White Wiuter Pearuaiu. Large oblong, skin yellowisl, flesh yellow, with a pleasant sub-acid flavor; tree vigorous, productive. January to April.

Willow Twig. Large, roundish, greenish yellow, striped with dull red; flesls firm, rather tough, early bearer and considered valuable in the Sonth and West, where it is popular; profitable as a late keeper; mod. January to May.

Whe Sap. Medium, dark red, sub-acid, excelleut, abundant hearer, a favorite market variety iu the West; vig. November to April.

Wolf BIrer. An apple peculiarly adapted to the West on account of its extreme hardiness; very large and handsome, flesh whitish, treaking, pleasant, sub-acid; a good bearer. Nov. and Dec.

Walbrldge. Mediun size, striped witl red, handsome and of excellent quality; vigorous grower and productive; very hardy, and considered of great value in the North and Northwcst. December to January:

Winter llay. Fruit medium to large, roundish, conical, pale greenish yellow, slightly brownisls in the sun, flesh whitish, fine grained, compact, not very juicy, nild sub-acid, core rather large aud open, good; tree a bushy grower, good bearer, valued in Kansas. February to June.

Winter Sweet Paradise. Rather large, ronndish, skin pale greenisls yellow with a brown blush, flesh white, very good flavor, tree upright, bears well, fruit inclined to drop prenature on some soils. December and January:

York Imperial. Medium, oblate, white, shaded with crimson, flesh firm, crisp, juicy and sul-arid; a good bearer and keeper, one of the best winter apples; nod. November to April.

\section{CRAB APPLES.}

The improvements in the varieties of the Crab Apple have kept pace with the otluet kinds of fruit. A few years ago it was regarded fit only for cider, preserves and jelly, but there are varieties now that command a good price on the market for dessert purposcs; especially is this the case with the Whitney. Besides being useful, they are also very ornanental when in bloom, and also when loaded with their lighly colored fruits.

The following are the most valuable varieties:

Mlaska. Of Northern origin. Fruit large, almost white, tree hardy, vigorous grower. Iniglıly recommeited.

Briar's Sweet. A novelty in the line of crabapples, being sweet; vig. Septenber.

Golden Beanty. Medium size, yellow, with red cheek; very handsone; mod. Septemher.

fien'l firant. Tree a vigorous and npright grower, fruit large, red to very dark red, nesil white, tender, mild sub-acid, excellent for dessert; free. October.

llewe's Vircinia. A variety highly esteemed for cider. A poor grower

Ilyslop. Almost as large as Early Strawberry Apple, deep criınson, very popular on acconnt of its large size, beauty and hardiness; vig. September and October.

Large Red Siberian ('ral,. About an inch in diameter, grown in clusters, yellow, lively scarlet cheek, bears young and abundantly; vig. Angust and September

Ifartha. A seedling of Duchess of Oldenburg, which originated in Mimnesota. Farlier than the Transcendent; very ornamental as well as a fine fruit; bears in profusion every year. Sep. tember and October.

Moutreal Beanty. One of the most beautiful of the crabs, fruit large, briglit yellow, sladed with red; flesh yellowish, firm, acid; tree a free grower. September and'October.

Quaker Beauty. A hardy, strong growing sort; bears large crops of fule fruit. December to May.

Qqueen's Choice. Fruit as large as Transcendent, but a little more elongated; bright yellow witl a beautifulfush cheek; grown in large elusters, flesh fine grained, juicy and good; an early and abundant bearer. October. 
Swept liwsit. (Summer Swect Russet). A very large cral, clear russet; an excellent sumuner variety. In Wisconsin they call it the finest summer erab; placed at the head of the erab list by the Wis. State fort. Society. Sweet Russet is almost equal to a good pear in quality; and the best of its scasol1.

Sylvan Sweet. Tree slender, upright, light eolored wood, fruit large, pale yellow, with rich blush, flesh white, tender, very good and very beautiful. July.

Shields. A new crab from Wiseonsin. Tree free from blight and a vigorous grower, fruit large to very large, red, splashed with yellow.

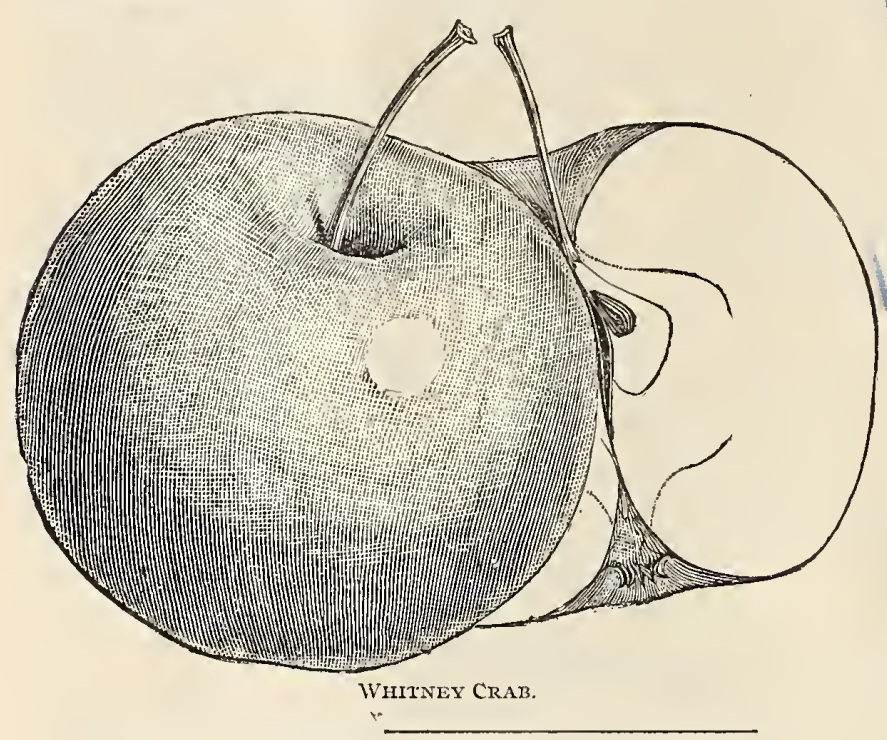

frauscendent. Tree productive, fruit from oue and a half to two inches in diameter, excellent for sauce and piès, and is a1so a good eating apple; skin yellow, st riped with red; vig. August and Sept.

Whitney's No. 20. $\mathrm{I}_{\text {rarge, }}$ aver a $\mathrm{g}$ i $11 \mathrm{~g}$ one and a half to two inches in äia meter; skin smooth, gloss y green, striped and splashed with c a rmine; flesh firm, juiey a nd rich; a great bearer and vety. hardy. Tree a vigorous, handsome grower, with dark green, glossy fo $1 \mathrm{iage}$. Alig. and Sept.

\section{PEARS.}

The growing of this valuable fruit for both home and market purposes cannot be too strongly urged. It far exeeeds the apple in its mclting, juicy texture, rieh refined favor, and the tange of varieties is such that by a judieions selection, the ripening season beginniug in July can be continued in succession into winter. It is a mistaken opinion among some persons that standard pears are a long time eoming into bearing. Many of the varieties begin to bear in four to six years after transplanting, and some of the newer varieties, sueh as the Kieffers, will produce fruit as soon as the dwarf pear, whieh is usually two to three years after transplanting. The pear when onee in bearing seldom fails to produce a crop of fruit aunually.

Gatheriug Pears. In order to retain the juice and best flavor, suminer pears should be gathered at least ten days before they are ripe, a1td autum11 pears at least two weeks; winter varieties as soon as the leaves begin to drop.

Thining the Funit. When the trees are heavily laden the fruit should be thinned when about onethird grown else the fruit will be poor and the trees injured.

'The letters, "D." and "S.," appended to the description of varieties, indieate favoralble growth either as "Dwarfs" or "Standards" or both. 'Those designated as "moderate growers" are nsually smaller trees.

\section{SUMMER PEARS.}

Notice. Those with star are of reent origin or introduetion.

Bartlett. L,arge size, with often a beantiful blush to the sun; buttery, very juiey and high flavored, bears early and abundantiy, very popular, D. and S. rig. August.

Bloodgood. Medinm, yellow, touched with russet, rich and delieious; first quality; I). and s. Free. J11ly. 
Beurrafifard. An excellcut variety, uedium, greenish yellow, red in the sum, very early, very productive. 1). and s. Mod. July

Brandy wime. Above necliun, yellowisli green, melting, sweet, productive, I). and s. Vig. July. Brockworth Park, or Bonny DFuev. A new, large and beantiful pear, juicy, melting and excellent. D. and $\mathrm{s}$. jirec, August.

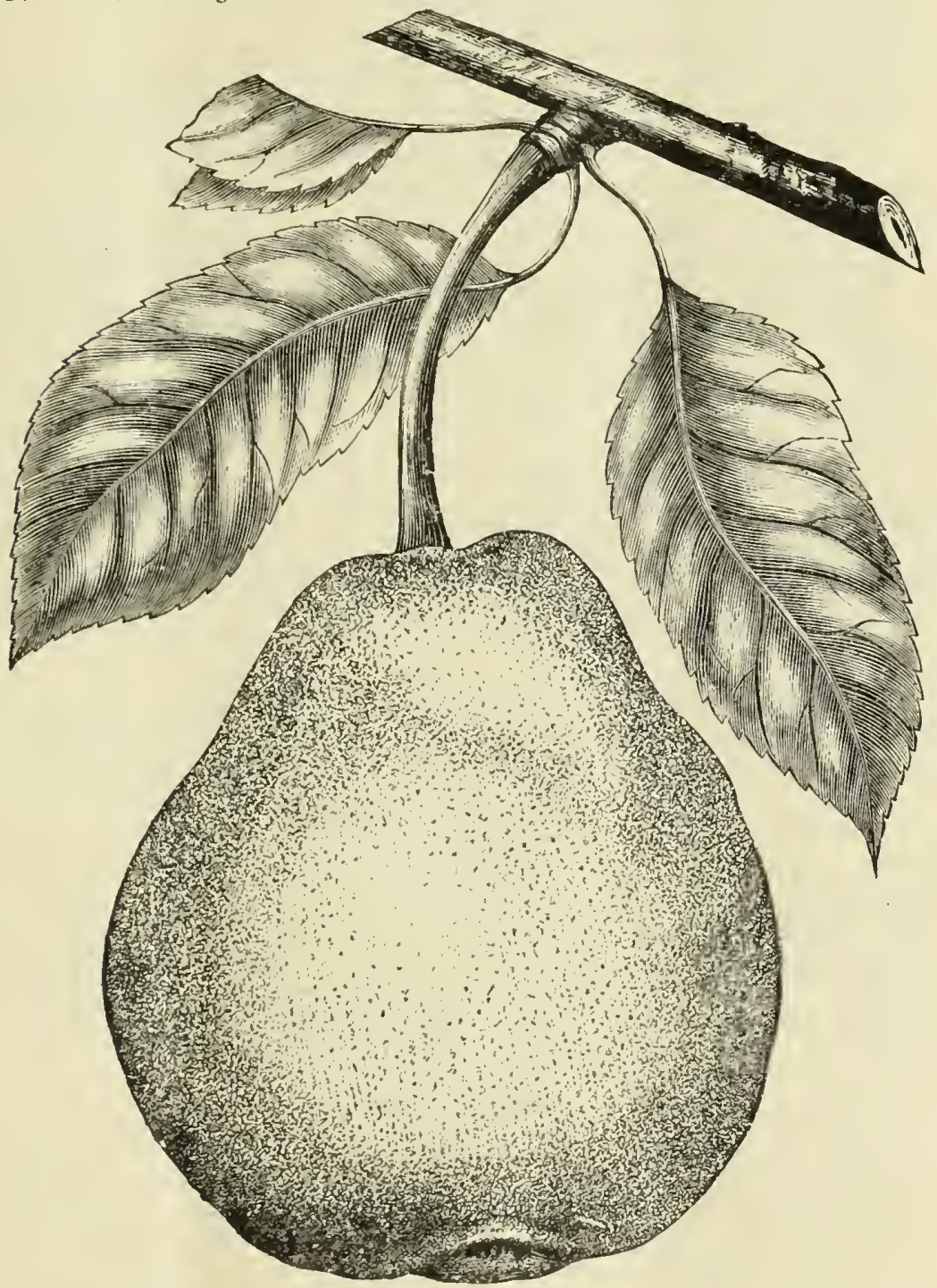

WIIDER's Fiarly PEAR. (See neat page.)

Chanbers'. Farly Harrest, of Kentuchy', Originated in Maryland and valued as a profitable early variety. Recomnucuded Ly the Kentucky IIorticultural society as the best and wost profitable market pear of its season. Fruit mecium to large, rich, golden yellow, with red cheek next the sun, thickly covered with gray dots, D. and t. Mod. July. 
Clapp's fiavorite. Very, large, yellowish green to full yellow when ripe, marbled with dull red in the sun, and covered with small russet specks, vinous, melting and rich, D. ands. Vig. July.

Dearborn's Seedling. Nearly medium in size, light yellow sprinkled with small dots, juicy, inelting and fiue: an abundant bearer, D. and S. Free. July.

Doyenne D'Ete. Scarcely medium size, yellowish with a fine blush, juicy, sugary and rich, very early, fine on quince, D. aud S. Vig. July.

Early Harrest. This variety originated on the Ohio river about 100 miles West of Cincinnati, where it is planted as a valuable market variety. The tree is very vigorous and long lived and more nearly free from blight than any other sort in cultivation. The fruit is large golden yellow with a fine red cheek, flavor poor, but it sells well in the market because of its size and color and earliness in ripening; ripens one month before the Bartlett.

Kingsessing. Large, greenish yellow, flesh juicy, buttery, with a rich perfumed flavor, D. and $\mathrm{S}$. Vig. August.

* Lawson. (Comet). Fruit large for so early a pear, the larger specimens measuring more than nine inches in circumference; sufficiently firm to insure its being a good shipper; of brilliant crimson color on yellow ground; flesh crisp, juicy and pleasant; yet like many of our most popular market fruits not of highest quality, but what it lacks in flavor is offset by its charming exterior, being one of the most beautiful things imaginable iu the way of a pear. D. and

s. July.

Mandeline. Medium, yellowish green, very juicy, melting, sweet; a fair grower aud productive; D. and S. Vig. August.

Manning's Elizabeth. Small to medium; bears in clusters, crimson and gold color, very beantiful, melting, rich, sugary, sprigbtly perfumed flavor; excellent; very productive, one of the best early pears; vig. July.

Osband's Summer. Medium; yellow with red cheek, half melting, uild and pleasaut, fine flavor and excellent; productive; D. and S. Free. July.

Souvenir de Congress. Fruit large to very large, resembling in form the Bartlett, skin smooth, of a handsome yellow at maturity, washed with a bright red or carmiue ou the side exposed to the sun; flesh much like the Bartlett, having the musky flavor, though in a less degree; D. aud S. Mod. August.

Tyson, Medinn size; bright yellow, cheek shaded with reddish brown, buttery, very nelting, flavor uearly sweet, aroma excellent; D. and S. Vig. August.

*Wilder Early. Size medium, greenish yellow, with a brownish red cheek and numerous dots; flesh white, fine grained, melting, excellent, about three weeks earlier than the Bartlett.

\section{AUTUMN PEARS.}

Buffum. Mediun size; yellow, somewhat covered with reddish brown and russet, buttery, sweet, and excelleut; D. and S. Vig. August and September.

Beurre Clairgeau. Iarge; yellow, shaded with orange and crimson, covered with russet dots, flesh yellow, buttery, juicy, sugary, perfumed vinous flavor. The size, early bearing, productiveness and exceeding beauty render tbis a valuable sort. D. and $\mathrm{S}$. Mod. Sept. and Oct.

Beurre Bose. A large fine pear; russety yellow, slight brownish red in the sun, flesh white, inelting, juicy, sweet, perfuned, productive. S. Mod. August and September.

Bell Iucrative. Large, yellowish green, slightly russeted, melting and delicious; productive; one of the best. Free. August and September.

Beurre d'Anjou. Iarge greenish, sprinkled with russet, sometimes shaded with dull crimson. flcsh whitish, buttery, melting, with a high, rich, vinous, excellent flavor, very productive, succceds well on quince, sbould be in every orchard. D. and S. Vig. September to December.

*Cole's Pear. Originated at Detroit, Kansas. The tree is a vigorous grower in nursery; young and annual bearer; has no core whatever, and is practically seedless. The leathery carpels which surround the seeds in ordinary pears and apples, are entirely absent. Quality good to best; size, medium to large; color, bright yellow when fully ripe; seasou September to November.

buehess d' Angouleme. Very large, dull greenish yellow, streaked and spotted with russet, flesh white, buttery and very juicy, with a rich and very excelleut flavor; on the quince, to which stock this variety seems well adapted, it is always fine; the large and fiue appearance of llis fruit makes it a general favorite. D. Vig. September and October. 
Dogenne lbouswih. Ifirge, lemon yellow, a littlc russetẹl; melting. juicy, with a sprightly, vinous flavor, s. Vig. september.

kdmunl. 1,arge, hright yellow, often marked with red in the sun; melting, sweet perfuned, good bearer. 1), and s. Free. September.

Flemish bunl!. 1,arge, beantiful, juicy, melting, rich and fine; goot hearer; lardy everywhere. b. and s. Vig. August and september.

Frederirk Clapp. Abore mediun, lemon yellow, sprighlly, acidulous, rich, superior to Benrre Superfine; best. liree. September and October.

Vuriser's lly loril. Is kin to and very much like Kieffer's; but is larger and of letter quality, and ripens two or tlire weeks earlier. Is as yellow as an orange, immensely productive, bears at three years from the mursery. A valuble market fruit.

Ilowell. Iarge, light, waxed yellow, with a fiue red clete, liandsome, rich sweet, unelting, perfnned aromatic flavor. An early aud profuse bearer. Very hardy and valuable. D. aud S. Vig. August and septenber.

Idaho. A seedling, raised from a large, red-clseeked pear, by Mrs. Mullkey, of Lewiston, Idaho. The tree fruited the fourth year from the seed, and has borne aunully ever since. It has survived winters when the thermoneter ranged from 15 to 30 degrees below zero. The fruit is evenly distribnted over the tree; sometimes in clusters. The combined weight of a cluster of four was $81 \frac{1}{2}$ onnces; the largest weighing 23 ounces. Color, greenish yellow with russety spots; form, roundish; flesh, melting, jnicy; flavor, good, rich, sprightly, vinous; core, exceclingly small and witlout seeds. Season septcmber and October. Subject to blight in some localities.

-Kleffer's Hybrid. This pear was raised from seed of the Chinese Sand Pear accidentally crossed with the Bartlett or sone other kind grown near it. Tree has large, dark grcen glossy leaves, and is of itself very ormaneutal; is an ea.ly and very prolific learer; the fruit is of good qual. ity, wonderfully slowy, and is valuable for the table and market; it never rots at the core, and is as ncarly blight-proof as it is possible for any pear to be. S. Vig. September and Oct.

Louise Boun de Jersey. Rather large, greenish yellow, with a bright, red cheek; juicy, buttery and nelting, excellent; very productive. D. Vig. August and scptember.

If conte. Irighly recommended, flesh melting, sweet, juicy and aromatic; this is one of the leading new sorts for the south, too tender North.

Onundaga. (Swan's Orange). A very large, melting and highly flavored yellow pear; vigorous and productive. September. D. and $\mathrm{S}$.

Rnttur. Fruit large and nearly, globular; skin rough, greenish yellow, sprinkled with russet: flesh white, moderately juicy, nearly" melting, sweet, slightly vinous; good bearer; very goou; tree an exceedingly strong, vigorous grower, early and abundant bearer and not subject to blight. October and November.

Sheliton. Medium size, yellow on greenish russet, with a riclily shaded cheek; flesh a little coarse, melting, juicy, with a very brisk, vinons, highly perfuned flavor; productive. s. vig. Sept.

Nerkel. Small; skin rich, yellowish brown when ripe, with a dnll brownish red cheek; flesh very fine grained, sweet, excedingly juicy; melting, buttery; the richest and highest flavored pear known; vig. August and Septenuber.

smith's Hybril. Resembles Le Conte in tree and fruit, but is of better quality and a little bater. superior to I.e Conte and has the advantage of being hardy.

\section{WINTER PEARS.}

lentre kaster. I,arge yellow, sprinkled with brown dots, often dull red cheek; quality gond; one of the best winter pears; best on quince. D. Mod. Novenber to January.

Duchess de Borleanx. I, arge size with a very tongh thick skin, which renders it a nost valuable keeper for winter use; flesh ucltiug, juicy, rich. S. Free. November to February.

1.an rence. Rather large, yellow, covered with brown dots: flesh whitish, slightly granular, somewhat buttery, witl a rich aronatic flavor, unsurpassed anong the early winter pears; succeeds well on the quince; ripens with little carc; should bc in every orchard; tree healthy, hardy and productive. S. Free. November and December.

\#.. Vermm. MIedium size, light russet, redish in the snn; flesh ycllowish, juicy and aromatic; carly bearer; a very good late pear. D. auds. Free. December. 
Wicar of Wakefleld. L,e Cure). Large, long, not first quality, but desirable for its productiveness; best on quince. D. and S. Vig. November and December.

Winter Nelis. Medium size, yellowish, green and russet; fine graincd, melting, rich and delicious; one of the best winter pears; very productive. S. Mod. December.

\section{PEACHES.}

The Peach Tree requires a well drained, moderately rich soil-warm, sandy loam is probably the best.

In order to preserve the continued healthy growth of the tree and the fine quality of the fruit, the Peach sliould have the shoots and branches shortened in every year or two, so as to preserve a round, vigorous head; and the land should not be sceded to grass, but kept in constant cultivation.

The following have bcen selected as the best, including many new varieties which are indicated by a star prefixed. They furnish a succession for over four months, commencing about July 1st :

A Arkansas Traveler. Said to ripen earlier than Ansden, of which it is a seedling; fully equal in evcry respect.

Alexander Early. Large size, wcll growu specimens measuring eiglit inches in circumference, hand some and regular in form, with deep maroon sliade, covered with the richest tint of crimson, rich and good in quality with a vinous flavor; adheres to the stone; should remain on the tree until fully ripe. Last of June.

Amsdem. Fruit mediun; color red, beautifully shaded and mottled with a very dark red, nearly covering the greenish white ground; flesh white, with a delicious flavor when ripened on the tree. Middle to end of June.

Briggs' Red Mny. Above medium; very highly colored; flesh greenish white, very juicy; viıous, and of very good quality; adheres somewhat to the stone; of firm texture; tree very prolific. Ripens with the Amsdeu.

Banurd's Early. Medium to large, cheek purplish red; flesh yellow, red at the stone; juicy, sweet and rich; one of thc very best yellow fleshed free stoned peaches. Middle of July.

Bonanza. Free, u1edium; flesh white, red cheek, fine quality, vigorous, productive, sıre. For a really finc freestone, fiftecn days later than Salway, we are at last rewarded by this true Bonanza to the peach grower. October.

Blood Cling. Large size, color dark claret, with veins, downy; flesh deep red, very juicy, fine flavor; tree an irregular grower. October.

Blood Free. Medium to large size, blood red throughout; tree hardy and a good bcarer.

"The Champion. Originated at Nokomis, Illinois; fruit large, beautiful in appearance; flavor delicious, sweet, rich and juicy; skin creamy white, with red cheek; freestone. August 15th. The peculiarity of this great acquisition is its hardiness, and the crowning events in its history of its having stood a temperture of $18^{\circ}$ below zero in the winter of $1887-8$, and produced an abundant crop the following season, and again in 1890 producing a full crop, when the pcach crop was a universal failure.

Chinese ('ling. Most popular Southern peach, innense size, oblong, creany skin, witl faint flashes of red. August.

Crawford's Early. This beatiful yellow peach is highly esteemed for market purposes. Fruit very largc, oblong; slin yellow, with fine red cheek; flesh yellow, juicy", sweet and excellent; productivc; free. Last of July.

Crawford's Jate. Fruit of the largest size; skin yellow, or greenisli yellow, with dull red cheek; flesh yellow; productive; one of the best; free. Last of August and September.

('rimson Beanty. Cling, white flesh, one-half surface covered with bright crinsou, very large, fine quality, vigorons; flesli sliglitly red close to the pit; prolific. Last of september.

Velhair's ('hoire. Origin, Maryland; has no superior in quality and flavor, and for profit is witl1out a rival; large, yellow, free, rich in color, flesh very firm, and ripens after smock; great bearer. 
Early Rivers. Large, light straw color, with delicate pink cheek; flesh juicy and melting, with very rich flavor. First of July.

Volberta. A Georgia cross between Crawford and Chinese cling, very large, well colored; all things considered the finest yellow freestone in cultivation; 110 one can go amiss by planting it; fruit perfectly free from rot, and one of the most successful shipping varieties. August 20 th.

Eldred Cling. Creamy skin, with red cheek, white flesh, large. July 15 th.

Foster. Large, deep orauge red, becoming very dark red on the sunny side; flesh yellow, very rich and juicy, with sub-acid flavor; earlier than Farly Crawford; very handsome; free.

* Family Farorite. Free, seedling of chinese cling, of better color, large, clear, waxen complexion with blush, prolific, firm, valuable for shipping, canning or drying. Last of July.

theneral Lee. An inproved Chinese Cling; rery valuable. August 20th.

(Aeorge IY. Large, white with red cheek; melting, juicy and delicuous; moderate bearer; free. First of August.

Globe. An improvement on Crawford's Iate; fruit large, globular, of a rich golden yellow with a red blush, flesh yellow, juicy. August.

Innest John. Medium to large, yellow; flesh yellow aud of good quality; tree vigorous and productive; free. Middle of August.

Honrletta. (Levy). The most magnificent yellow cling known, largest size, mostly covered with bright crimson, hardy, productive, sure bearer; always commands faucy prices. Sept. 25 th.

Hale's Early. Fruit mediun size; skin clear, smooth, white, delicately marbled with bright and dark red on the sunny side; flesh very melting, juicy, and high flavored. July 10 th to 20 th.

Heath Cling. Large, oblong, creamy white, slightly tinged with red in the sun; very tender, juicy, melting; very rich and luscious. September 15th.

Keyport White. Iarge, pure white, and white at the stoue; hardy, a strong grower, and very prolific; more free from mildew and cracking than most white freestone sorts, and oue of the best and most reliable of this class.

Large Early York. Large, white, with red cheek; fine grained, very juicy, riclı and delicious; vigorous and productive; one of the best; free. First of August.

Jemon Cling. (Pineapple Cling). Large, oblong, having a swolen point similar to a lemor; skin yellow with red cheek; flesh yellow, firm, juicy and sweet; tree a fine grower. August.

Large Red Rareripe. A most excellent peach; fruit large; skin greenish white, dotted, and with a beautiful rich red cheek; flesh white, redat the stone; melting and juicy, with a sweet and rich flavor; free. August.

* Lemon Free. Almost lemon shape, pointed at the apex, colot a pale lemon yellow when ripe; it is of large size, the finest specimens measuring over twelve inches in circumference, of excellent quality, ripens after the Late Crawford, is immensely productive.

Hammoth Cling. Resembling Heath Cling, but double its size; originated in Sonthern MIissouri. September 20 th.

Monntain lhose. Iarge, red; flesh white, rich, juicy, excellent; one of the best early peaches, rip. ening with 'Troth's Early, and much larger and finer than that variety; should be in every collection. July.

Irs. Brell. Free, large, white with red cheek; an improved old Mixou Free; a little earlier and the finest in quality. Angust 20th.

May's Choice. Large yellow freestone, Iripening with Reeve's Favorite, which variety it vei y much resembles, but is decidedly superior to it in size and appearance; prolific and a valuable market pearh.

0lı Mixon ('ling. Large, pale yellow, with red cheek; juicy, rich and high flarored; one of the best clingstone peaches. August 20 th.

0ld Mixon Fren. Large, pale yellow, with deep red cheek; rich and good; one of the best. Aug.

Picquet's Late. A Georgia variety of large size; yellow, with red cheek; flesll yellow, melting, sweet, of the higliest flaror; freestone; a valuable acquisition. Septenber.

Ringrold Cling. Mncli larger than Heatl, everyway an inprovenent on llut popular kind. September 1 st. 
Reere's Farorite. Fruit very large, round; shin yellow with a fine red eheek; flesh decp yellow juicy, meltiug aud excellent; tree lardy and produetive; one of the best and most reliable yellow market peaches. I ast of July.

Salway. Fruit large, ronndish, deep yellow, with a deep nuarbled brownish red elicek; flesh yellow, firm, juicy, rich and sugary; a new Finglish variety; a late showy market sort; frce. Last of September.

smock Free. Frnit large, ova1, skin orange yellow, nottled with red, a good market sort. Sept. 15th.

Sneed. The most reniarkable early peael jet introdueed; it ripens a week to ten days earlier thau Alexander, and belongs to an entirely different type from Alexander and Hale's Early; it is very distinet $i_{1}$ tree and fruit, belonging to the chinese Cling type; size medium, color white with flusli on eheek.

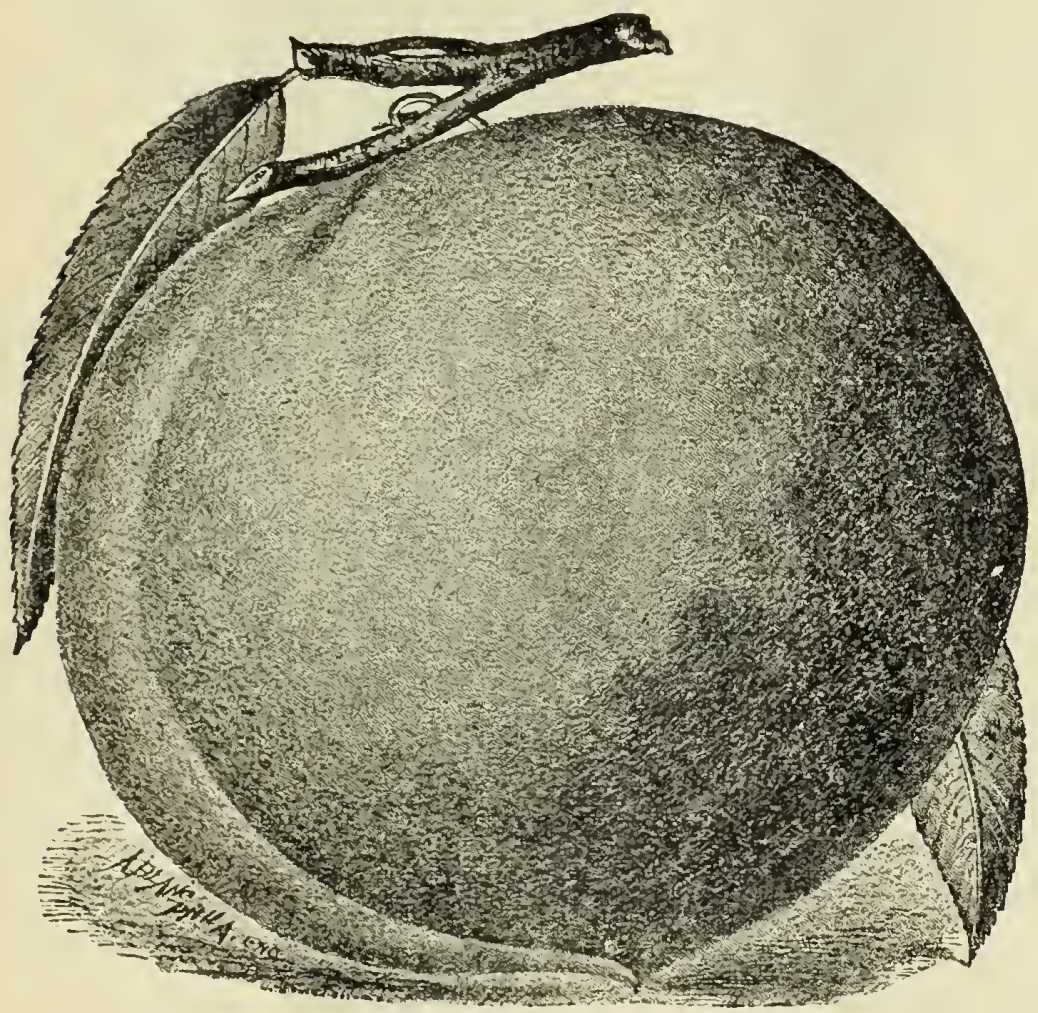

The Champion.

Stump the World. Very large, toundisln; skin white, with a lriglıt red cleek; flesh white, juicy and good; free. Find of Augist.

Susquehanua. One of the handsomest peaclu's; large, yolluw and red, netting, lich and good; origin, l'ennylvailia; free. September.

Troth's karly. A very early and execllent peacll of undiun sia; whitisl, with a very fine red cleek; flesh jniey, sweet and vory goul: ome of the nost pupular and profitalie varieties for early marketing; free. Midlle of J11 y

Van Buren's Golden Inarf. Very ormanenta1; fowers small; frtit medim, gollen yellow, with a rich, moltled earmiue elicck; flesh yellow, firm, juicy, sprightly; eling. September. 


\section{a}

Wager. Very large, yellow, more or less colored on sunny side; juicy and of fine flavor; free. First to middle of August.

"Wheatland. Large, ronudish, skin golden yellow shaded with crimson on the sunny side; flesh yellow, rather firm, juicy, swect and of fine quality; tree vigorons. August.

Wald's Late Free. Medium to large; yellowish white, with a red cheek in the sun, flesh nearly white, juicy and good; valuable for late preserving; tree vigorous; free. September.

Wyandotte Chief. A fine early peach, ripens with Alexander, and of extra good size, and of finest quality.

Walker's Variegated. Free, large, white, striped, handsome, sells at sight, very vigorous. A most excellent variety for canners. September.

Wonderful. Originated in New Jersey, large to vcry large, nniform in shape and size, color rich golden yellow, overspread with carmine and crimson; flesh yellow, highly flavored and firm, bright red at pit, which is small and parts freely from the flesh. Ripe in October and keeps we11.

"Yellow Cobbler. Free, large, resembics Salway, but is several weeks later. It is the best very late peach. Origin, Grayson County, Texas.

*Yellow St. John. Large, flesh yellow, equal in flạvor to Crawford's; exceedingly valuabl- for an early market variety. Free. July.

\section{PLUMS.}

Diseases and Enemies of the Plum. The prevalence of the disease of the plum commonly known as the "Black Knot," which has so much discouraged people in the eastern states from giving to the plum its merited share of attention, has as yet done but little damage west of the Mississippi river, but its appearance slould be guarded against, and its ravages prevented by keeping the trees in healthy condition, which is donc by good cultivation, and removing the Knot by amputation on its first appearance. Nothing is more favorable to the growth of the black fungus or knot than neglect. But the great enemy of the plum is the insect known as the Curculio, a small, dark brown beetle which punctures the fruit in depositing.its egg from which is hatched the destructive grub, and causing the fruit to drop prematurely and rot. Twoways of destroyiug this Curculio and saving the crop of fruit is recomincnded, viz:

First. Spread a large sheet prepared for the purpose nnder the trce and then jar the tree so as to shake down all fruits that have bcen stu1ng, as well as all the curculios; both insect and stung fruit are destroycd. Begin to do this as soon as the blossom falls, and keep it up daily, or at least tri-weekly until the fruit is half grown. The morning is the best time to do this when the insect is chilled and stupid.

Second. 'The best remcdy aud the one generally adopted now doubtless is the spraying of the trees, directions for which is given in the last pages of this catalogue. If those who really desire to grow fine crops of this most delicious fruit will try either of these systcms and follow it up rigidly they will be successful.

Bralshaw. Fruit very largc; dark violet red; flesh yellowish green; juicy and pleasant ; prodnctive. Vig. Middle of August.

Coe's Golden Drop. Large and handsone; light yellow; firm, rich and sweet; one of the best late plums. Mod. Scptember.

Damson. Fruit smal1, oval; skin purple; covcred with b1ne bloon ; flcsh meltingand juicy, rather tart; separates partly from the stone. Mod. September.

Fellenburg. (Italiau Prune). A fine late plum, ova1, purple; flesh juicy and delicious; parts from the stone; fine for drying. Tree very productive. Free. September.

General IIand. Very largc; ova1; golden yellow, sweet and good. Vig. August.

German Prune. A large, long, oval variety, much estcemed for drying; color, dark purple; of very agreeablc flavor. Vig. September.

Inperial Gage. (Flushing Gage, Prince's Imperial Gage). Fruit large, oval; skin pale green; flesh juicy, swect, rich and cxcellent. 'Irce very productive. Vig. Middle of August.

J.fferson. I,arge, yellow; redlened in the sun; juicy, rich and delicions. One of the best. Mod. Last of Auginst. 
large fiolden l'roliflc. New; a scedling originated in Outario, Canad:ı, resenubling in color and fornu, Yellow Egg, of which it is snpposed to be a seedling, lunt of much better quality and more productive. The original tree bears free crops every year. We consider this a valuable acquisitiou to the list of plums. Sufficiently hardy for cultivation in Canada. Vig. I,ast of August.

Iombard. (Bleeker's Scarlet). Medium, round, oval; violet red, juicy, pleasant and good; ad. heres to the stone; productive. A valuable market variety; one of the most hardy and popular. Vig. Last of August.

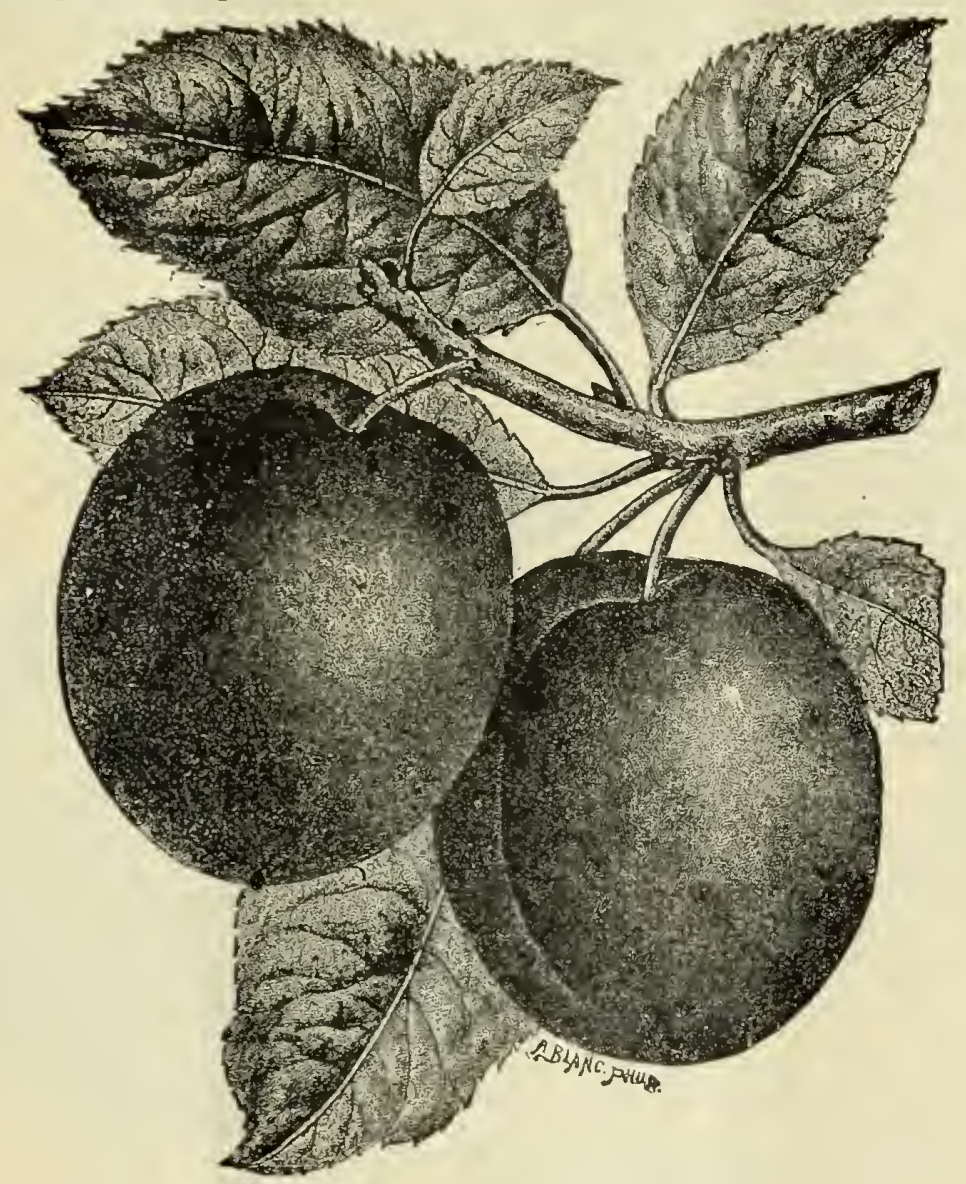

SHIPPER'S PRIDE.

Lawrince's farorite. Large yellowish green, remarkably juicy and melting. One of the best; productive. Mod. Middle of August.

Peach. Very large and handsome; dull red; good; very productive. Free. I,ast of August.

Pond Seedling. A magnificent English plum; light red, changing to violet; flesh rather coarse; abundant bearer. One of the most attractive in cultivation. Vig. September.

I'urple Fgg. (Iudson River Purple Egg'. Highly esteemed by growers along the Iludson River; described as one of the richest and finest flavored plums we have; stone free, good size, resembles the German Prune-a little larger with a nice bloom; good bearer and brings a good price in market; tree bears young. Vig. September and October. 
Qunckeuhoss. Large, oblong, oval, deep purple; a little coarse, spright1y, juicy, swcet and excellent. Adheres slightly to the stone; productive. Valuable for market. Vig. Octobcr.

Shipper's Pride. This plum originated in northwestern New York, near the shore of Lake Ontaric and has never been known to freeze back a particle in the severest winters. Size large; colot dark purple; flesh firm and excellent quality. Vig. First of September.

Smith's Orleans. Large size; reddish purple; flesh firm and juicy with a rich fine flavor; produc. tive. Free. September.

Shropshire Damson. A plum of fine quality, as free from the attacks of the curculio as the Com mon Damson, and of the same color. The flesh is amber colored, juicy and sprightly. In mar. ket it has commanded nearly double the price of the Common Damson, and is enormonsly productive. Free. Last of September.

Washington. Very large; when ripe, clear yellow, marked with red; flesh firm, very juicy and ex. cellent; very popular; productive. Free. Last of August.

Yellow Egg or Yellow Magunm Bonuum. Very large; egg-shaped; excellent for cooking; prnd and productive; Vig. Last of August.

\section{NATIVE AMERICAN PLUMS.}

Notice:--Those with star are of recent introduction.

*Arkausas Lombarl. Originated in Arkansas; trees are vigorous, sprcading and enormous bcarers. It is an improvemcit on the Wild Goose, and far sitperior in flavor. Fruit yellow, with red blusli, firm, meaty and luscious. Ripens two weeks later than the Wild Goose. July.

Forest Rose. Cr row th like Miner.

Forest Garden. Large, nearly round, mottled red and yellow, juicy, very sweet and rich; tree a strong grower. July.

De Soto. Medium; bright red; sweet, rich, of fine quality. Fxtremely hardy and productive.

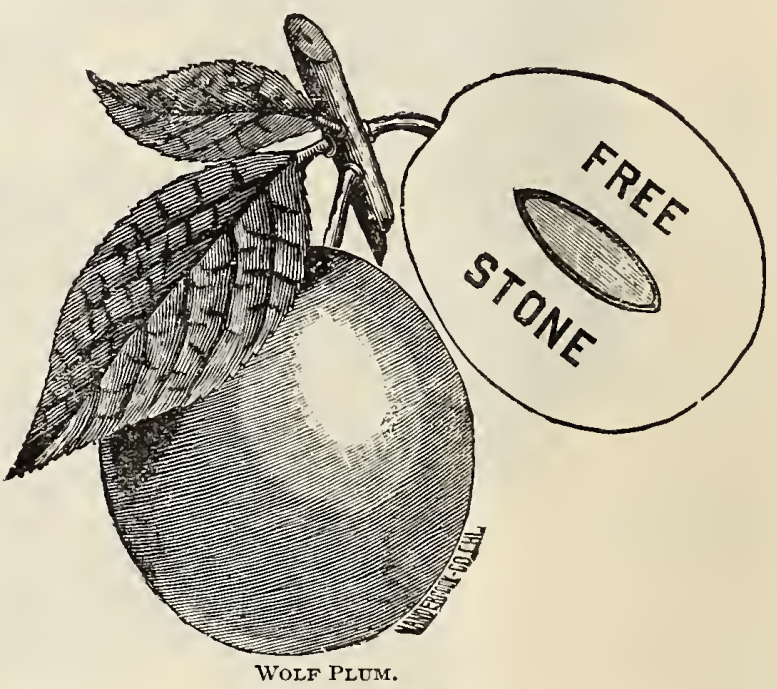

Golleu Beauty. Round, large as Wild Goose; rich golden yellow; very firm; small secd, nca: :y free, excellent in quality, immensely productive, free from curculio, large, light, glosiy f, zec i leaves, young wood, yellow when mature; endures drout1 well. This plum is astonishing : $: 1$ who see its ropes of rich golden fruit, vieing with the apricot in quality. September.

Miner. (Townsend). Mediun size; oblong, skin dark, purplish red; flesh soft, juicy, vinous anul adheres to the stone; excellent for canning and cooking, and esteemed for market; productive.

Mariana. Fruit large; round, of a singularly rich red color and most magnificent appearance; is not blown off by winds; skin rather thick; stone smal1, quality excellent; good for shipping and market. July. Free. $\Lambda$ good grower.

fottawattamie. Perfectly hardy and an immense carly annual bearer; fruit is yellow, orerspread with a bright pink and prominent white dots; flesh yellow, luscious, good; ripenn in July. 
Quaker. Very large; globular; a little flattened at the end; purplish red blusl orer a whitish yellow ground; fesh yellow, crisp, juicy, rich, meaty, very firm, adhercs to the stone. Vig. Middle of August.

Wearer Plum. Flesh firm, rich, juicy, with a flavor resembling the abricot; stone free; early bearer and very productive; hardy and curculio proof. August.

Wild Goose. Large, rich, crimson, beautiful; flcsh soft, rich, melting, delicious, with a full fruity flavor; tree a strong grower, prolific. 'This variety is anong plums what the Ben Davis is among apples-referring to the American class of plums. July:

"Wolf. Fruit nearly as large as Loubard and a perfect frce stone; quality superb for cooking and for serving with sugar; tree a good grower, hardy, and is bccoung very popular wherever known, promising to lead all other native plums. Angust.

\section{JAPAN VARIETIES.}

A unique class of Plums, of great bcauty and productiveuess. The fruit is exquisitely perfumed, with a charmingly attractive bloom. Trees are exceedingly ornamental, with smooth branches and rich, light green foliage, and quite distiuct from other varieties, early and prolific bearers. The flesh is so firm and meaty that they can be safely shipped long distances, and kept for a long time in excellent condition.

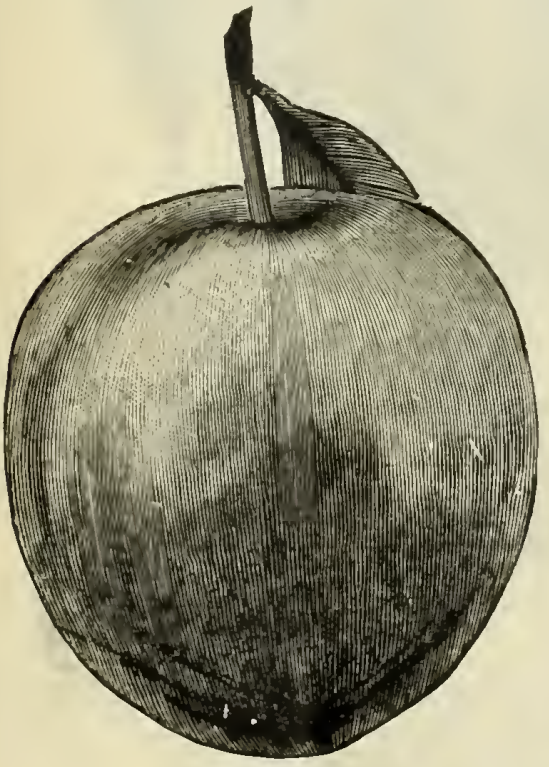

BOTAN OR ABCXDANCE.

Botan or lbundane. This remarkable plum is being catalogued by" some under the uame of Abundance on account of its wonderful bearing qualities. It is one of the imported Japau varieties, the correct name being Botan. It is so remarkably strong and handsome in growth and foliage as to make it an ornament to any yard. It excels in early and profuse bearing. The fruit is large, handsome, showy and practically curculio proof; fruit beautiful lemon yellow ground, nearly overspread with bright cherry and with a heavy bloom; large to very large, oblong, tapering to the point; flesh orange yellow, melting, rich and highly perfumed. July.

Burbank. The best of all the Japan sorts of pluns; nearly globular, clear cherry red with a thin lilac bloom. The flesh is a deep yollow color, very sweet, with a peculiar aud very agreeable flavor; tree vigorous, with strong, upright shoots, large, broad leaves! commences to bear usually at two years. It blooms late and consequently more likely to escape the late spring frost.

*Kelsey. 'The pioneer of the Japan plums. Was bronght into noticc in 1 s.1 by the late John Kelser, of Califoruia, after whom it was named. Fruit very large, heart-shapel, being from scren to nine inches in circunference and, spccimens weighing six and a half onnces each; color a rich ycllow, nearly oversprearl with bright red, with a lovely bloom; fesh firm, meaty, rich, of cxccllent quality; trce a fair grower, but not stocky, with long, willowy, light colored shoots. Angust and septculber.

*0gon. I.arge; ncarly round, with deep suture, of a bright golden yellow, with faint blooul : flesh firm, sweet, rich and dry; tree vigorous and entirely hardy; excellent for canning. First of July.

RTunus Simont. Apricot Plum'. This remarkable plum came from Northern China; fruit large, cinnamon red color; the flesh is firm, rich, sweet, aromatic, and delicions pineapple ningled with bauna flavor; tree an upright growcr, long hauging lcaves, distinct. July. 
Prunus Pissardii. From Persia; this is a very ornamental tree with purple foliage; fruit is medium in size: roundish, oval, dark crimson color, juicy and fairly good, but desirable for cooking; hardy and productive; free frcm curculio. For full description see ornamental trees.

Visatsuma Blood. A fiue large plum of the Oriental class, 1arge as Kelsey, more globular in shape and from five to six weeks earlier; the flesh is solid, of a purplish crimson color from git to skiu, juicy and of fine quality; pit exceedingly small-very little larger than a cherry stone; tree a strong, vigorous grower with a brownish-red bark aud lanceolate foliage.

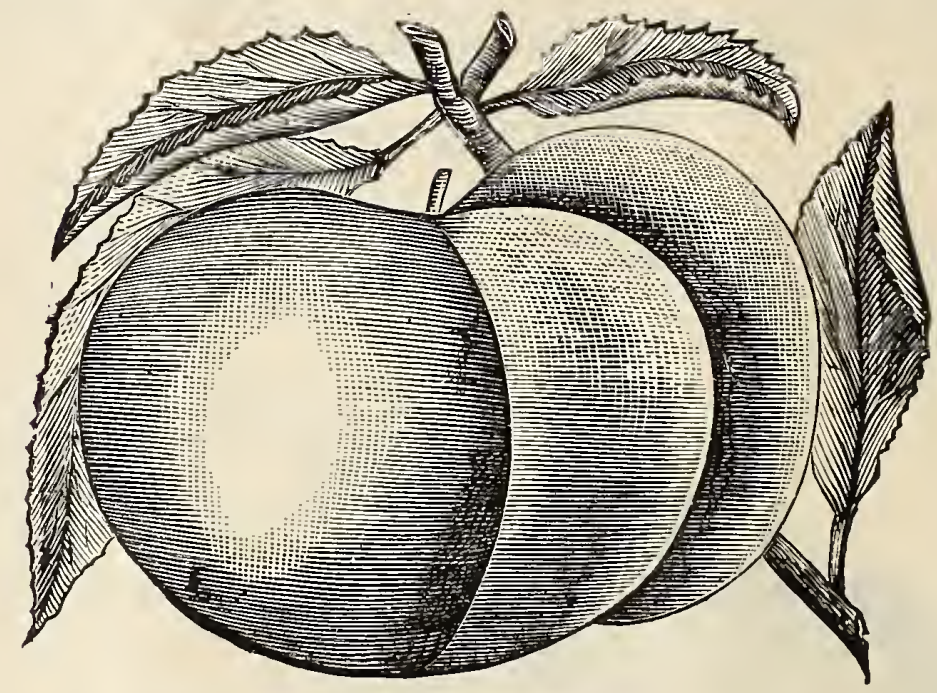

PRUNUS SIMONI.

*Sweet Botan. Said to be superior to the Botan or Abundance; the tree a marvel in prolificness, fruit reddish purple on sunny side, large, solid and said to be curculio proof.

\section{CHERRIES.}

A great deal of attention is now given to the growing of Cherries. No home orchard is complete without its proportion of Cherry trees, and it is one of the most profitable market fruits. It will succeed on any kind of soil that is not wet.

The Heart and Bigarrea varieties are not so much of a success in the west and Southwest as in the Eastern States, but the Dukes and Morellos succeed everywhere, especially the latter.

Cherries are now generally worked on the Mahaleb, a stock that does not throw up sprouts from the roots.

\section{HEART AND BIGARREAU VARIETIES.}

llack Eagle. Large black, very tender, juicy, rich and high flavored; productive. Free. Middie of June.

Hlack Tartarian. Very !arge, bright purplish black; half tender, juicy, very rich, excelleut flavor, productive. Vig. First of June.

Downer"s Iate Red. Large, light red, tender, juicy and delicious; productive. Vig. Middle of June.

Early l'nrple fuigue. (Early Purple). The earliest fine variety; medium size, heart shape, tender, juicy and sweet; very hardy and productive. Free. May and June. 
Gov. Wood. Raiscl by Dr. Kitkland, and one of the best clucries; very large, light red, juicy, rich and delicious. Tree healthy and a great learer. Vig. First of June.

Luelling. A new variety from Portland, Oregon; said to be the largest cherry known; of very dark color and finest gluality, flcsh solid and firm, and adapted to long transportation. Free. Middle of June.

Napoleon Blgarrean. Vcry large, pale yellow or red; very firm, $j u$ icy and sweet; very productive; one of the best. Vig. Middle of June.

Ohlo Beauty. (Dr. Kirtland. I.arge; mottled with dark and pale red, tender, juicy and fue. Middle of June.

Tellow Spanish. I,arge, pale yellow with red cleek; firm, inicy and excellent; one of the best light colored cherries: productive. Frec. Iune.

\section{DUKE AND MORELLO VARIETIES.}

Belle de Cholsy. Medium, auher, mottled with red; tender, juicy, sweet and rich. Vig. Middle of June.

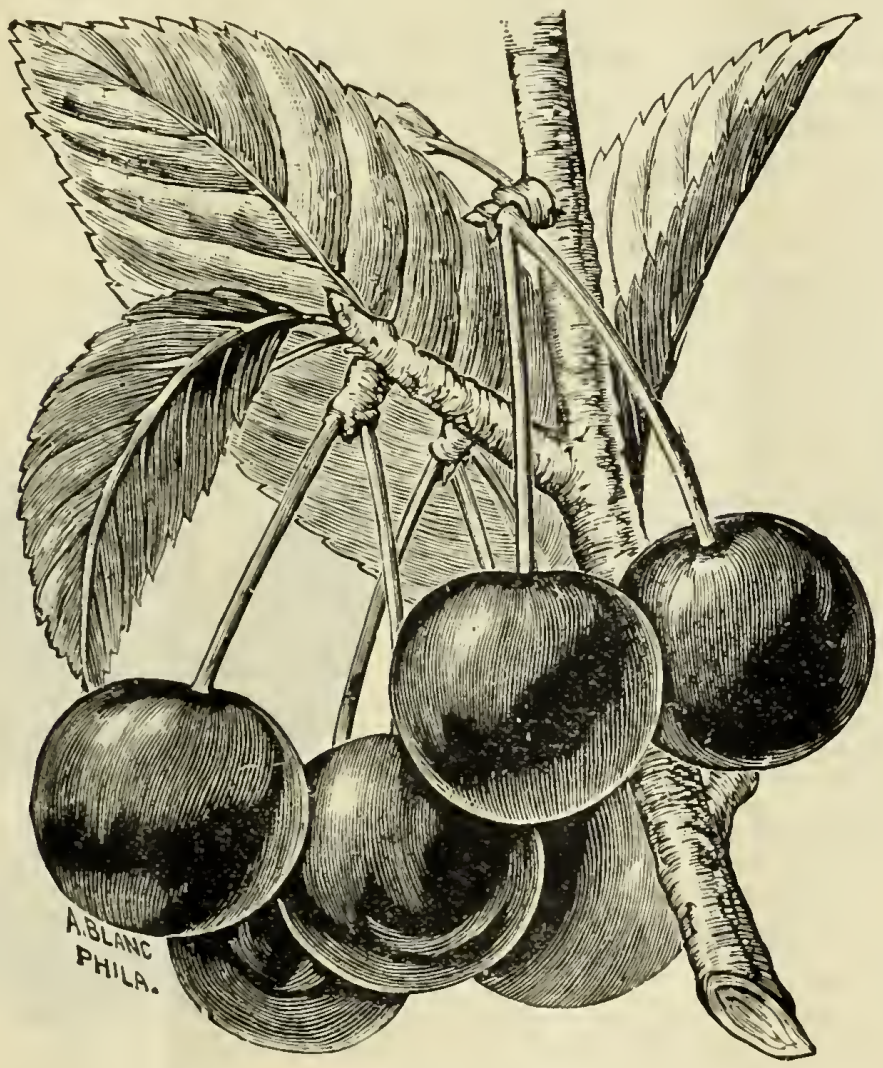

LARGE MIONTMORENCY CIIERRY.

Bell Magniflque. Iثruit large, roundish; skin hright red; fesh tcuder, jnicy, sprightly, sub-acid; one of the finest of this class of cherries. Tree hardy and very productive. Free. July. 
Vibrusseler Braune, A variety much prized on the sandy plains of East Poland. A larger growe: than Richmond, with good foilage. Fruit large, nearly round, purplish red in color, juice slightly red, flavor pure and quite acid. As it contains inuch grape sugar it is valuable for canning and drying. Later than English Morello.

Dye House. This variety partakes hoth of the Morello and Duke, wood and fruit; a very early and sure hearer; ripens a week hefore Early Richmond; of hetter quality and quite as productive. Free. May and June.

Empress Eugenie. Fruit large, dark red, very rich, tender and suh-acid. A superior variety. Mod. June.

Early Horello. Brought from Germany to Kansas City with the Ostheimer, hy Mr. Sauer. Fruit medium to large; hlack when fully ripe; tender, rich, vinous; ripens with Early Richmond; hears young, very productive; hest early cherry.

Inglish Horello. Medium to large; blackish red, rich, acid, juicy and good; very productive. Mod. July.

Early Richmond. (Kentish, Virginian or Early May). Medium size, dark red; melting; juicy, sprightly, acid flavor. This is one of the most valuable and popular of the acid cherries, and is unsurpassed for cooking purposes, and is exceedingly productive. Free. First of June.

Girotte Imperial. A small tree and an early hearer. Foilage hetter than Richmond. Fruit large, dark red, inclined to conical, flesh and juice red. Flavor pure and free from bitter erell when immature. Mild sub-acid when ripe.

Late Duke. Large, light red, 1ate and fine. June and July.

Yate Kentish. Fruit medium, round, deep red when ripe; very juicy, highly acid; one of the best for culinary purposes. Firee. June.

Large Moutmorency. A large, red, acid cherry, larger than Early Richmond, and fully ten days later. Free. Middle of Tune.

Louis Phillipe. Very productive, fruit large, roundish, regular; color rich dark, almost pnrplis $1_{1}$ hlack red, flesh red, tender, sprightly, mild acid; good to hest. Free. First of July.

Montmorency Ordinaire. 'Tree, a stout, hut slow grower. Ellwanger \& Barry say: "A heantiful, large, red cherry; larger and finer than Early Richmond, and ten days later. Being extraordinarily prolific and very hardy, it can be recommended as a variety of great value."

May Duke. Large, dark red, juicy and rich; not prolific. Free. First of June.

ostheimer. (Ostheimer Weichsel). This maguificent late cherry was taken to Germany from Spain in 1814, and hrought from there to kansas City where it was heginning to attract much attention ahout the time the Ostheim, a much inferior sort, was heralded ahroad; when without any apparent cause except the similarity in name, they were tacitly assumed to be identi cal-greatly to the loss of cherry culture generally. The Ostheimer has done remarkahly well, and is the cherry for the west. MIr. G. F. Espenlauh, of Kansas, says: "The best, most valuable and profitahle sort I have. Good grower, bears early, is very productive; fruit large, dark liver-colored when full ripe; juicy, rich, almost sweet."

olivet. A variety of French origin. Large, globular, very shining, deep red; flesh red, tender, rich and vinous; sub-acid flaror. Frec. Middlc of June.

linine IIortense. Very fine; large bright red, juicy and delicious. Vig. Last of Junc.

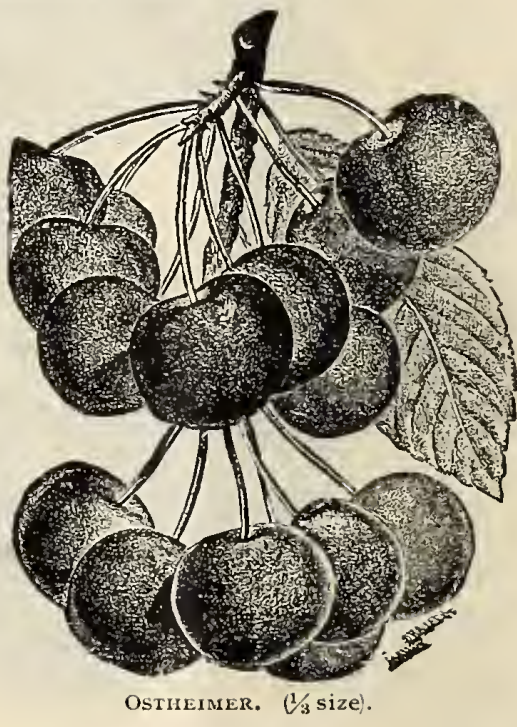

Suppington. Originated at St. Louis, Missouri, where it is grown extensively for mariel, and is acknowledged to be of first quality. Iarlicr than the Richmond: a good bearcr and a rigcp. ous grower. 
"Spate Imarelle. Mucl grown for dessert and culinary use in Fast Poland and North Silesia, where it is noted for its regular and bountiful crops. 'Tree smaller than Ènglish Morello with pendulous habit. Trees from fivc to six feet in lieight have borne heavy crops of fruit. Frnit medium to large, color dark purple when ripe. Flesh and juice colored. It is excellent for canning, and when fully matured is desirable for dessert use. Season about the 20th of July.

"Wragg. Originated in Iowa. Medinm to large in size, long stem, dark purple when fully ripe. A variety well adapted for the high latitude aud prairie regions of the northwest. July.

\section{NECTARINES.}

A most delicious, smooth skinned fruit, which thrives wherever peaches will grow, hut it is liable to be stung by the curculio, and requires the same treatment as plums.

Boston. Large, deep yellow, with a bright blush and mottlings of red, sweet and peculiar, pleasaut flavor; freestone; the largest and most beantiful variety known; luardy and productive. Vig. Angust.

Elruge. Medium size; pale green, with a dark red cheek; flcsh pale green, very juicy and rich. Free. First of Angust.

Hunt's Tawney. Mediun, pale orange; juicy, rich and excellent; very early and productive; the best of its season, and wortly of general cultivation on account of its hardiness; freestone. 1 Vig. First of August.

Rell Roman. Large size, greenish yellow, with a dark, dull, red cheek; flesh yellowish, fine and rich; productive. Vig. September.

\section{APRICOTS.}

A delicious fruit of the plum species, valuable for its earliness. It is liable to be attacked by curculio, and requires the same treatment as the plun; it bears immense crops; ripens in July and August.

"Acme. A new Apricot from Northern Clina which was given to Prof. J. I. Budd by a returned missionary. The tree is an immense grower, very hardy and productive; fruit the very largest size; a sweet and delicions freestone; yellow with red cheek.

Breda, Small, dull orange, marked with red; juicy, rich and vinous; productive and luardy. Free. First of July.

farly Golden. (Dubois'. Small, pale orange; juicy and sweet; hardy as the Russian Apricot, and productive, vig. First of July.

Harris. A new sariety, recommended for its good beariug qualities and extreme hardiness. It was brought into notice by orchardists at Geneva, $\mathrm{N}$. Y., who prize it highly as a market variety. It is equal in size and quality to the best cultivated sorts and should take the place of the Russian Apricot.

Moorpark. One of the largest; orange, with a red cheek; firm, juicy, with a rich flavor; very productive. Vig. July.

Peach. Very large; orange, with a dark clicek; juicy and high flavored; similar to groorpar?.. vig. July.

Royal. Large; yellow, with an orange cheek; juicy, rich and delicions; a very fine variety, and well deserving a place in collections. rig. July:

Russian Apricot. A new variety of recent introduction, valualle on account of extrene luardiness of trees and fine quality of fruit.

\section{IMPROVED RUSSIAN VARIETIES.}

Hexander. An immense bearer; fruit of large size, oblong, yellow flcked with red, flavor sweet aud delicions; tree hardy; one of the best. July 1 st. 
Alexis. Large to very large; yellow, with red cheek; slightly acid, but rich and luscious; tree hardy and abundant bearer. July 15 th.

*(iibb. Medium size; yellow, sub-acid, rich and juicy; the best early sort, ripening with the strawberry.

W. L. Budd. Of large size; white, with red cheek; flavor sweet, juicy, extra fine; a hardy, strong grower and profuse bearer; the best late variety. August 1st.

\section{QUINCE.}

The growing of the Quince, both for home and market purposes, is attracting - great deal of attention because of the many ways it can be madc use of in canning, prescrving and for flavoring other fruits, and also because of the remunerative prices it a1ways brings on the market.

No fruit will give a morc profitable returu for the labor put on it than the Quince. It needs but little pruning, enough only to remove decayed or dead limbs and such as are encrouching on nore important branches.

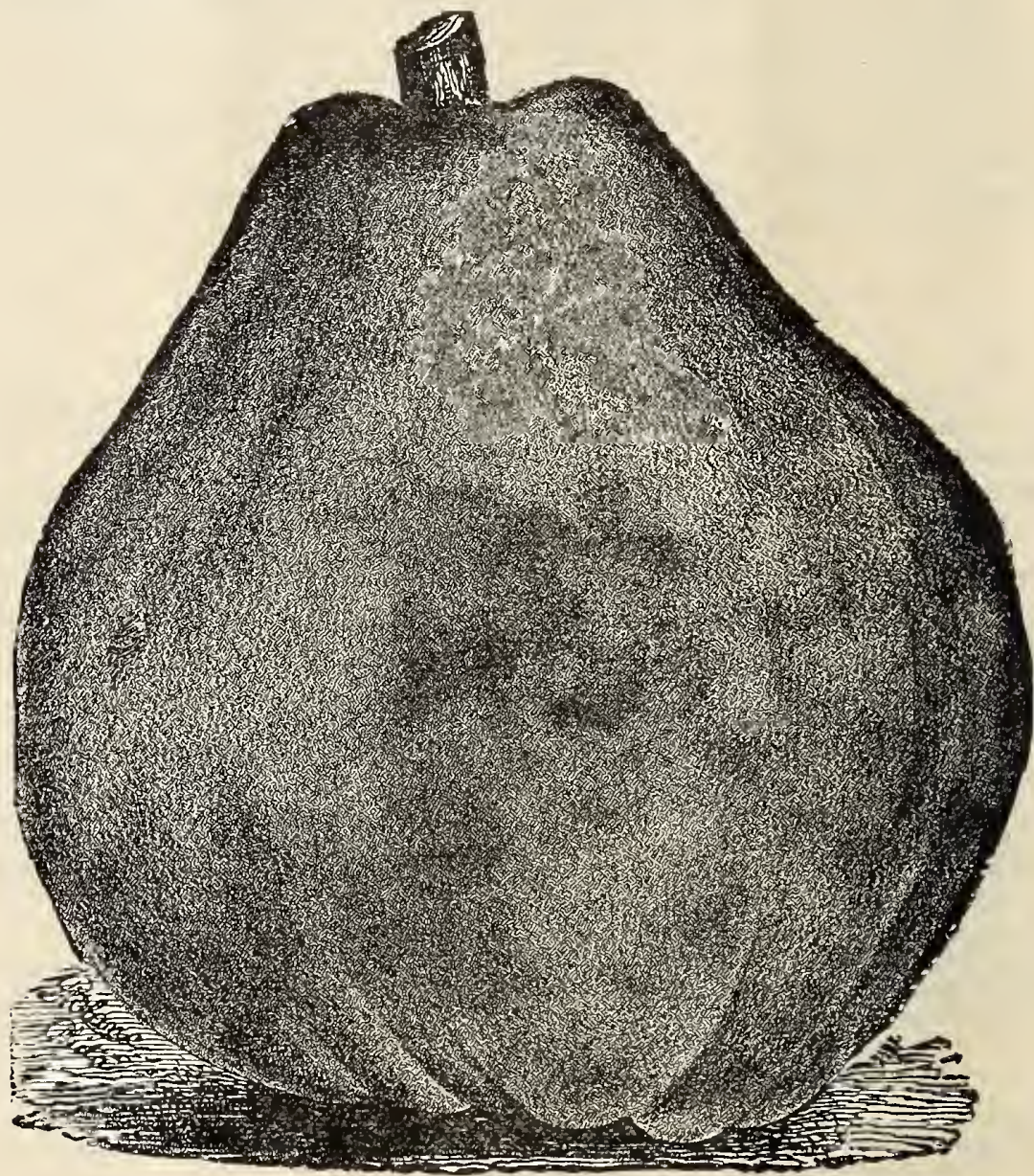

MisSOURI MAMMOTH. 
It may be grown in a careless way, but to be more sueecsful it requires peculiar eultivation. One of the best modes of cultivation for the Quince is given as follows:

I,ate in the autumn give the soil a top dressing with potash, or wood ashes, which is the best, thongh slneked lime or cow manure will do. Sprinklc some salt over the gronnd and then cover with a heary mulching of straw or lilter, say six or eight inches thick, to prevent the roots from severe freezing, and in the spring renove the unlching, placing it in piles near the trees, and cultivate the soil thoroughly until abont the last of June or first of July, at which time replace the nulching, which should again he removed in October and replaced about one month later after the ground has been top dressed as above directed, and continued in this way from year to y'ear.

Xple or Orange. Large, roundisl1; briglit goldcu yellow; cooks tender and is of very excellent flavor; valuable for preserves or favoring; very productive. Scptember.

Ciampion. A variety originated in Connceticut. The trce is a prolific and constant bearer; fruit averaging larger than the Orange, more oval in shape, quality equally fine and a longer keepVer. vig. Oetober and November.

Missouri Mammoth. The largest Quince in cultivation. Bronght into notice in the vicinity of Kansas City; Mo., where it is fruited extcusively, and is attracting grcat attention on account of its being large in size, perfect in shape, very rich and aromatic; trce vigorous, productive,

an early bearer and free from blight.

Meech's Prolifie. This is preeminenlly prolifie and vigorous; young trees benring profusely, large, $\checkmark$ beautiful golden fruit as handsome as the finest oranges; fiavor unsurpassed.

liea:s Mammoth. A sectling of the Orange Qnince; one-third larger; of the sane form and color; fair, handsonc, equally as good and productive. Free. October.

\section{MULBERRIES.}

Dor uing's Everbeariug. Color blue black; flesh juicy, rieli, sugary, with a sprightly, vinous flavor; tree ornainental as well as

$\checkmark$ fruitful.

Hick's Everbenring. Won. derfully prolifie. Said to be superior to the $y$ Downing.

Sen American. Fruit of the largest size, llack, delicious in flavor; an attractive lawn tree, with very large leaves of rapid growth; $\checkmark$ liardy.

Russian. This makes a good sliade and ornanental tree; growing full a 11 d symetrical; holding its leaves late in the Autumu. It is a rery rapid grower, bears fruit at two or three years of age, and every year. Color of the fruit varies some, but is generally black; very valuable.

White Mulberry. I* 5 it white and very sweet.

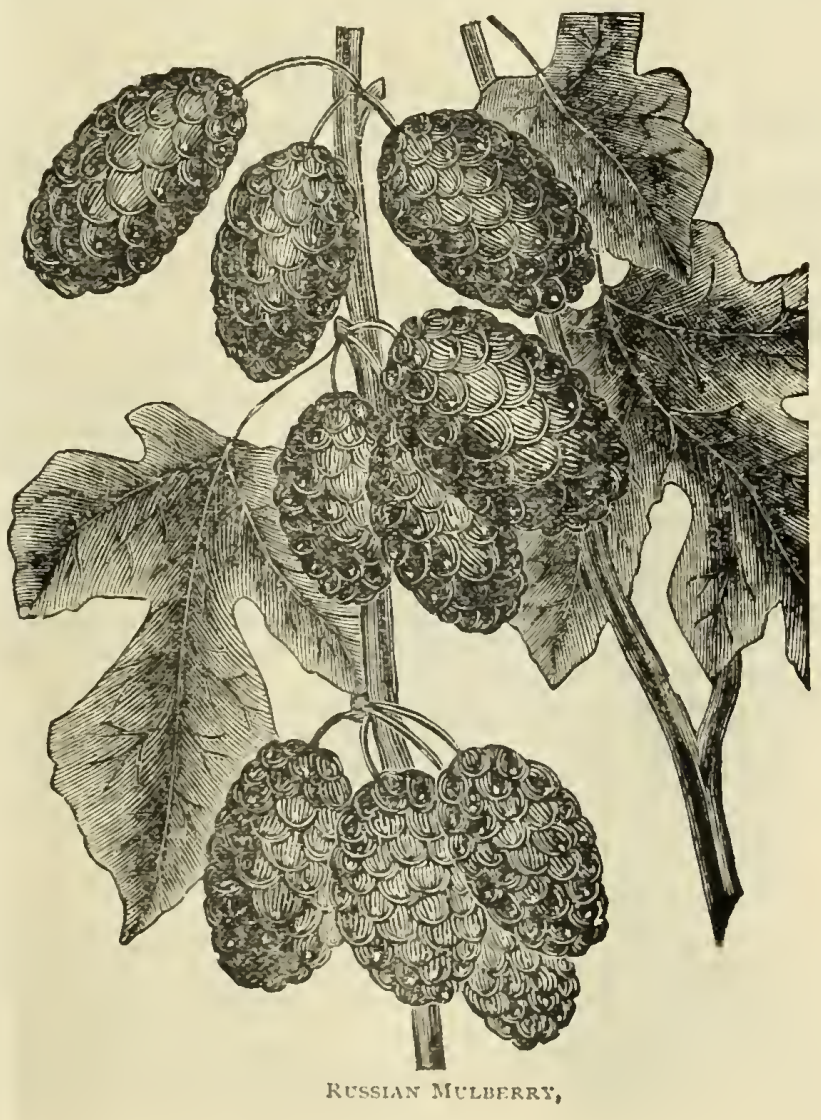




\section{DWARF SERVICE OR JUNEBERRY.}

Grows four to six feet high, bunches out from the ground like currants-resembles the Common Service or Juneberty in leaf and fruit, but the fruit is larger, and in color almost blackcommencing to bear the second year after transplanting, and bears profusely-no farm or garden should be without tlis most excellent dessert fruit.

\section{ENGLISH CLUSTER HOP VINE.}

'This is said to be very much superior to any other variety in cultivation. Plants can be sent by mail if desired.

\section{SCIONS AND BUDS.}

Can be supplied of most varieties of fruits, etc. Prices given on application.

\section{NUTS.}

Amond, Hardshell. A fine hardy variety, with a large plump sweet kernel, tree very showy and ornamental in blossom. The hull cracks when ripe, permitting the nut to drop out.

Almond, Soft or Paper Shell. This is more desirable than the Hardshell wherever it will succeed, is not quite as hardy. Kernel large, sweet and rich.

Butternut, or White Walnut. A fine native tree, producing a large, longish uut, which is prized for its sweet, oily, uutritious kernel.

Black Walnut. This is the most valuable of all our timber trees for planting, a rapid grower, producing a large nut. The timber enters more largely into the nanufacture of furniture and cabinetware thau almost any other, and is prized almost with mahogany.

Chestnut, Ameriean. Our native species; smaller than the Spanish, but sweeter; very hardy.

Chestnut, Spanish. A tree producing nuts of very large size and good flavor; not quite as hardy as the American.

Chestnut, Japan or Giant. Introduced from Japan. 'The tree is decidedly ornamental, hardy and productive, of dwarf habit, bearing extremey young; nuts of enormous size, and of the siveet, rich flavor of the American Chestnut.

English Walnut, or Maderia Nut. A fine, lofty growing tree, with a handsone spreading head; it is scarcely hardy enough here, but further South it is a profitable tree to plant, as it produces large crops of excellent $\mathrm{nuts}$.

Filbert, English. The fruit of these is so much larger and better flavored than out native species as to give them the preference for cultivation over the latter in localities where they will succeed.

\section{GRAPES.}

The history of the Grape is almost as old as that of man. Vineyards were extensively planted before orchards or collections of other fruit trees were at all common, and to-day it is one of the most highly appreciated fruits. In its flavor it is hardly surpassed by any other fruit in delicacy and richness, and few or none are more beautiful in the dessert. Any person having a lot of ground ever so small, either in country or city, can find room for from one-half to one dozen or more Grapevines. They can be trained up the side of any building or over a garden fence, but the best and cheapest way to grow them either in small or large quautities is on the wire trellis, 
Work the ground deep and plant a little deeper than they were in the unrsery. Make the rows eight feet apart and six to eight feet in the rows. Some of the tender varieties wonld be benefitted by laying the vines flat on the ground during winter, with a light covering of earth or litter.

The new varielies are indicated by a slar prefired.

\section{SELECT VARIETIES.}

\section{BIACK GRAPES.}

"Bacchus. Very hardy in wood, leaf and fruit; very productive, bunch compan, about six inches $\checkmark$ long, berry medium in size; pulp lialf tender, juicy and sprightly.

Clumpion. Bunches large and compact; berrics large, covered with a rich bloom; medium in quality; vine a strong and healthy grower and a good bearer; profitable for market on account of its earliness.

Clintou. Bunches medium size, compact shouldered, berries small; flesh acid vinous flavor. vines lardy, vigorous, productive, but improves by hanging long on the vines.

Concord. Bunches large, berries large, round; skin thick and covered with bloom; flesh juicy, sweet. Vine very liardy, vigorons and productive; at present the most popular of all ont native sorts.

Cyuthiana. Very similar to Norton's Virginia; always reliable, one of the surest grapes we have; keeps remarkably well, and is very sprightly and spicy; a good grape for winter use.

Eumelan. A medium sized, hardy, productive, melting grape; bunches compact, shonldered; flesh tender, sweet, sprightly and vinous; ripens early.

kurly Victor. In bunch and berry it is rather bclow the average, but ripens very early, is very pure in flavor, with very little pulp, is exceptionally sweet, sprightly and vinous; nevercracks, and adheres firmly to the bunch.

Hartford Proliflc. Valuable in Northeru localities. Ihuclies large, compact, shouldered; berry large, round; skin thick; flesh swect, juicy; vine vigorous and exceedingly productive, Ripens two weeks before the Concord.

Herbert. (Rogers' 44, Bunch large, compact; berry large, tender, sweet and rich; early and productive; a liandsone variety.

lves. Hardy and productive; valuable for warket on account of its earliness.

Jeneil. Seedling of Delaware; the earliest and best grape of high quality; fully tested, buuch wedium; shouldered, compact; berry medium; skin rather tough, slightly pulpy, sweet, rich, sprigltly, vinous, of the best quality; vine not vigorous until fully established; free from rot and mildew; will hang on vine long after tipe, and ships well.

Merrimac. (Rogers' No. 19). Bunches large; berries very large, round; one of the best.

Moore's Early. A large black grape of the Concord type, the entise crop ripcuing before the Concord; bunch nedium, berries large with blue bloom; flesh pulpy, of mcdium quality. Vine hardy, moderately productive, better as it attains age. Planted exteusively as a market sort.

yatchless. Bunch very large, compact, handsome; berry very large, pure, swcet, sprightly, vinous. with a slight pulp; ripe about with Jcwel; liardy; lrealthy, vigorous, and productive; frec from rot and mildew; will hang on the viue long after ripe.

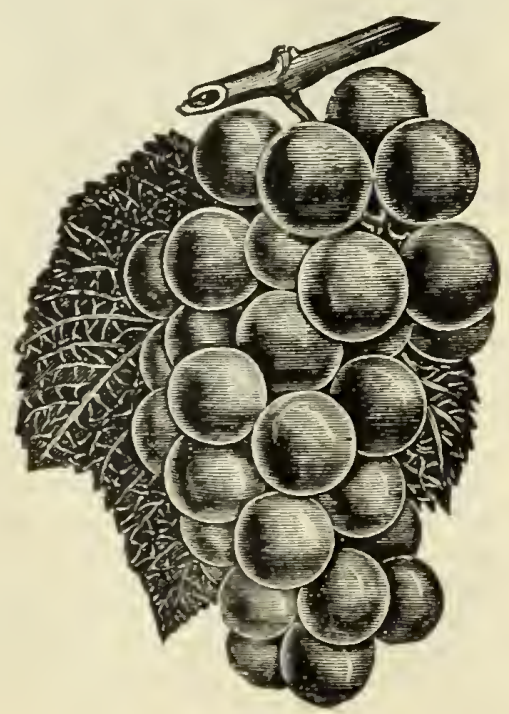

MIOORE:'S VHKLI: 
Norton's Virginia. Well known as one of the most reliable and healthy wine grapes; will also keep well for winter use, and though small is very sprightly.

"Ozark. Of astivalis type; large in bunch as Concord and almost as large in berry; a prodigious grower. The fruit hangs on the vine until cut; a rich, meaty grape, of a peculiarly pleasant flavor; hardy, healthy, and productive; free from rot and mildew; valuable for late market.

Paragon. Bunch large, shouldered, compact, handsome; berry large, tender, sweet, rich, sprightly, vinous, without pulp; a bag of delicious juice; hardy, healthy, vigorous, and productive; free from rot and mildew; ripe with Concord but hangs well; valuable table and market grape.

*Superl. Bunch medium, compact; berry medium, tender, without pulp, sweet, rich, sprightly, vinous; quality excellent, vine hardy, healthy and productive; free from rot and mildew; very early.

Superior. Bunch medium, compact, handsome; berry medium, very tender, sweet, rich, sprightly, vinous, without pulp; quality best; ripe about with Jewel; vine very strong grower, liardy, healthy, and productive; free from rot and mildew.

Telegraph or Christine. Early; good quality, and hangs to the bunch well; bunch medium. very compact; berry inedium, with blue bloom; productive and desirable.

Wider. (Rogers' No. 4). Perhaps the most valuable of the black hybrids, as it is healthy, strong and of excellent quality, also very productive; bunch heavy, shouldered, often weighing a pound; berry as large as Black Hamburg; round, thin skin, tender pulp, juicy, sweet and sprightly; ripens before Concord.

*Worden. This variety is a seedling of Concord, which it greatly resembles in appearance and flavor, but the berries are larger, the fruit is better flavored and ripeus several days earlier.

\section{RED GRAPES.}

Amber. (Taylor Seedling No. 8). Bunch large, shouldered, moderately compact; berry medium, oblong, pale amber when fully ripe; sweet, juicy, very tender pulp; thin skin; very fine flavor: very productive, hardy and healthy; late.

Agawam. (Rogers' No. 15). Large, round, early and of great vigor of growth; rich, high, peculiar aromatic flavor; very much subject to disease, and too high flavored, where all its aronla is developed, to be very desirable.

Amber Queen. Very early, hardy and a strong grower; tender to the center and small seeds; buuch large and shouldered like the Hamburg; berry large, frequently oblong, holds persistently 10 the bunch, and with proper care will keep all wiuter. August and September.

Brighton. A cross between the Concord and Diana Hamburg; bunches large, berries of medium size; flesh sweet, tender, and of the highest quality; ripens early; purple.

Catawba. Well known as the great wine grape of Ohio, Kentucky, etc.; bunches large and loose; berries large, of a coppery color, becoming purplish when well ripened; late. good, but liable to rot.

Delaware. Still holds its own as oue of the finest grapes; bunches small, compact, shoulderell: berries rather small, round; skin thin; flesh very juicy, without any hard pulp; an exceeding. ly sweet, spicy and delicious flavor; vine moderately vigorous; very hardy and productive.

Dracut Amber. Vine vigorous and productive; bunch large and long, compact, often shouldered; berries large, round; skin thick, of a pale color; very good.

Enreka. Seedling of Delaware; bunch large, shouldered, compact; berry medium, rich, sweet, sprightly, vinous; vine hardy, healthy, fair grower and productive; free from rot and mildew.

* Ileal. This fine red grape is one of Mr. Burr's seedlings of the Delaware, and is as large in bunch and berry as Concord and better in quality thau Dclaware; good grower, hardy, healthy and very productive; rots and mildews in some localities; this is 110 doubt the finest red grape, of large size, and wherever it can be successfully grown is very desirable.

Iona. (Dr. Grant). Bunches large, long, somewhat shouldercd and loose; berries medium, of a fine, clear wine color; skin thin; flesh tender, without pulp, with a sweet, brisk, vinous flaror.

"Jefferson. Bunch large, shouldered, often double shouldered, compact; berry medium to large, roundish, oval; skin rather thick, light red, with a thin lilac bloom; fesh meaty, yet tender. juicy, sweet, slightly vinous, aromatic and rich; a handsone, excclleut grape, eit her for mar'set or home use; ripens abont the time of Concord. 
I.Indley. Kogers' No.9. Bunches of medium size, rather long, compact; berry medium size, 6 roundish; flesh tender, juicy, sweet and good; ripens a little before the Concord.

Massasolt. Bunch mediun size, shouldered; berry largc, round, claret red; ficsh tender and juicy; ripens with the earlicst sorts; vinc a good grower and guite liardy, and one of the best varieties for a collt climatc.

Perklns. As early as Hartford; pale, with lilac bloom; sweet; fair quality; very productive aud healthy.

Aerfectlon. An early grape of the best quality; luuch long, slouldcred, compact; berry medium, swect, rich, sprightly, vinous; vine liardy, healtly, vigorous and very productive; free from rot and inildew.

Pouglkecpsio Red. A cross between Delaware and lona, of ligh quality and very handsome; larger y than Dclaware.

salem. (Rogers' No. 53). Bunclics large and compact; berries large, round; flesh tender, juicy, Bprightly, sweet and good; sipeus soon after the Delaware.

Yergennes. A Vermont seedling; hardy, rugorous and productive; quality good.

Wyomlng lied. A very early, medlum sized red variety; buncl sull but compact; skin bright sed, sweet, very ąreeable were It not for the slight foxy odor apparent when first gathered.

\section{WHITE GRAPES.}

Flvira. Ripens about with Cataba; a very strong, healthy and robust grower, very productive; bunch and berry of medium size, and very compact.

"Fmpire State. (Rickett's). A seedliug from Hartford Prolific fertilized with the clinton, hence very hardy' and vigorous; bunches large, long, shouldered; bcrry medium to large; flesh tender, juicy and rich, with a slight native aroma: ripens very early, and contiunes a long time $\sqrt{2}$ in use.

"Viclipse. Bunch large, double-shouldered, not very compact; berry very large, tonder, tich, sweet, sprightly, vinous, of excellent quality; vine

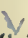
hardy, healthy, very vigorous and productive

(iolden Pocklington. Is a seeding from Concord; vine hardy, both in wood and foliage; strong grower; called a white grapc, but the fruit is a light goldcn yellow, cleat, juicy and sweet to the ceuter, with little or no pulp; bunches very large, sometimes shouldered; berries round and very large and thickly set; quality, when fully ripe, much superior lo Concord: ripeus with the concord.

"(irecn Ionntain. Winchell). This cxtra early delicious grape was found growing on the side of the Grecn Mountain in Vermont, at an altitude of 1,400 feet; supposed to be a chance secdling; color greenish white; skin rory thin; pulp exceediugly tender and sweet; contains but one to two seeds only, which separate from the pulp with slightest pressure; quality supcrh.

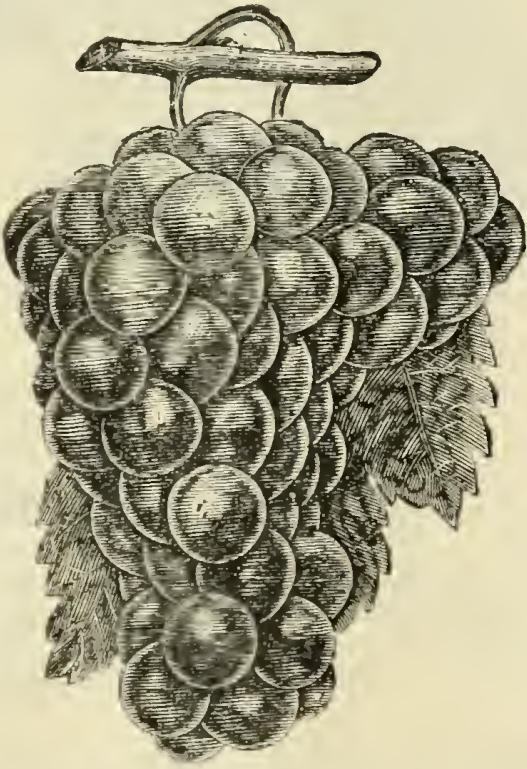

Golden Pockington.

Goethe. (Rogers' No. 1'. 'This is for the West decidedly the best of all the Rogers' IIybrids; bunch mcdium, rather loose, shouldercd; herry very largc, oval, very good, already when yet white, when it resembles the White Malaga; pale red with beatiful bloon when fully ripc; thin skin; tender pulp; very juicy, sweet and delicious; ripens aftcr Concord; exceedingly productive, vigorous and healthy, but should not be overtaxed when young, as like most of Kogers' Hybrids, it is apt to overbcar; very fine for market and talle. 
Lady. A seedling of the Concord; of medium size, white aud very good flavor; rery early.

$\checkmark$ Lady Washington. (Ricketts). Fruit yellow, tinged with pink; bunches very large, often weigh. ing a pound; vine strong, very hardy.

Martha, A seedling of the Concord which it resembles in growth and hardiness; bunch of good size, and bcrry large, of pale green or light color; sweet, juicy, sprightly; ripens with Concord.

Missonri Riessling. A very hardy and healthy grapc; bunch and berry medium, compact, pale yellow, changing to amber when very ripe; sweet, juicy and vinous; very tender pulp; quality best for table, and also makes rery fine winc, resembling the famous Riessling.

Moore's Diamond. Very hardy, liealthy and vigorous; ripens from 2 to 4 weeks earlier than Concord.

Ningara. A magnificent white grape and vcry valuable for both garden and vineyard; a rank growcr and rcry productive of bcautiful bunches of the largest size; berries large with a tough skin; quality good; ripens W. about with concord.

White Jewel. Bunch medinm, long, very compact, handsome; berry medium, vcry juicy, sweet, sprightly, of good quality; hardy, healthy, vigorous and immensely productive; free from rot and mildew; the earliest white grape.

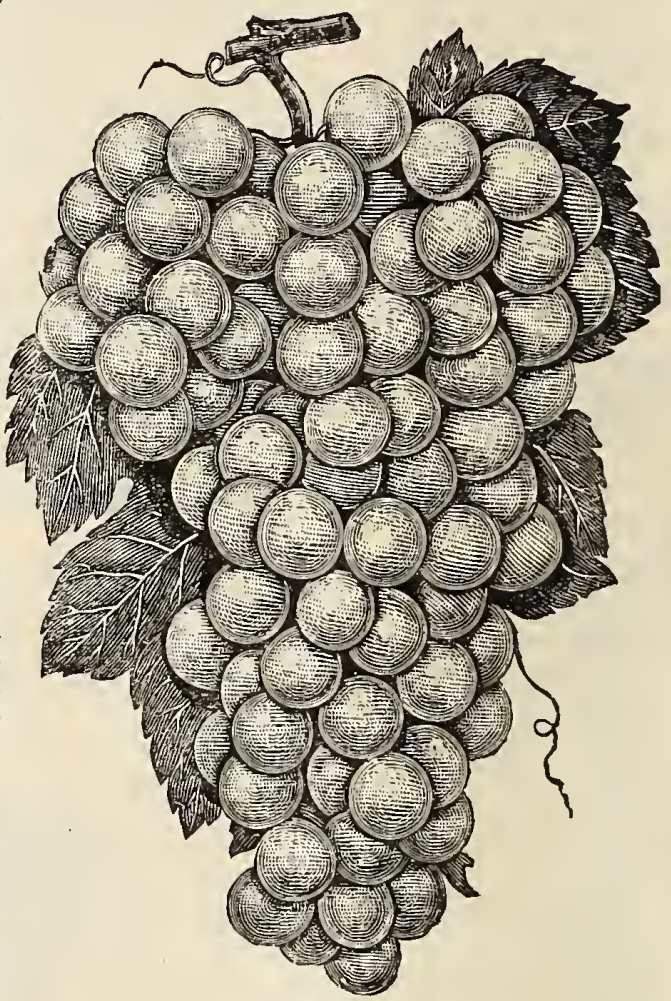

MOORE'S DIAMOND.

\section{RASPBERRIES.}

Plaut on strong soil, manure freely, cultivate well or inulch heavily. For field rows six feet apart, three fect in row. In gardeu culture, tie up to single wire. Cut out old wood each year.

\section{RED RASPBERRIES.}

Brandywine. An enormous producer; berry beautiful, highly colored and firm; the most valuable red Raspberry for trausportiug long distances, and brings a higl price in market.

Cuthbert, or Oneen of the Market. A remarkably strong, hardy variety, stauds the Northern winters and Southern summers equal to any; berries very large, measuring three inches around; conical; rich crimson; very handsome, and so firm they cau be shipped hunJreds of miles by rail in good condition; flavor is sweet, rich aud luscious.

Iansell. (The Earliest). Teu days ahead of all others, thus comuauding the highest price in market. 
Lurack. Ines short, hardy as the hardiest, producing large crops of beatiful fruit; very firm, rendering it one of the best for shipping.

Turuer. A beautiful red berry, of fine size and excellent quality; one of the hardiest and most productive varieties known.

"Thompson's Early Prolifle. An extra early variety, which has shown its value by its early season of ripening, productiveness and vigor of plant; it is admirably adapted for planting at the South.

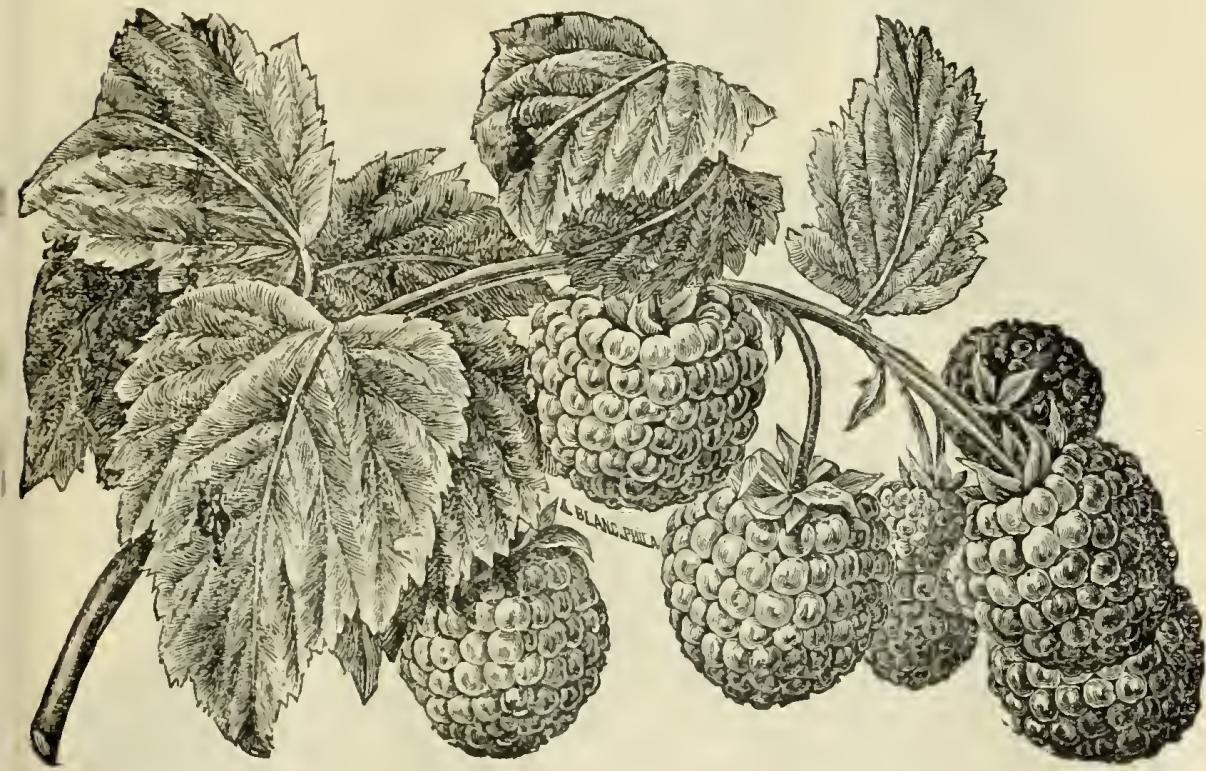

CUTHBert.

\section{BLACK CAPS.}

Earhart. Strong, stocky grower, with an abundance of stout, heary spines; very hardy; fruit of large size, jet black and of good quality, commencing to ripen early and continues till stopped by freezing in the autumu.

(iregn. The leading late Black Cap and a popular market sort; canes of strong, vigorous growth and, under good culture, very productive; berries are large, covered with heary bloom, firm meaty and of fue flavor; it requires a good strong soil to produce the best results; it is not en* tirely hardy, but suffers during unusually severe winters; it is by far the best late rlack Cap and the largest of any.

Hopkins. Resenbles soncwliat, in fruit and cane, the old Mammotl cluster, but an improvement upon it; canes very vigorous, lucalthy aud productive; one of the best early Black Caps and worthy of a place in all collections. It is grown more exteusively for the market in western and Southeru Missouri and Fastern Kansas than any other variety.

Johuston's Sweet. Its hahits are superior to Souhegan, ripens about the same time, but bush more npright in growth; entircly lardy, very productive, berry ucarly as large as Gregg, perfectly black, quite firm, holds its shape well in handling and shipping; in quality sweeter and more delicious than anything else in the Black Cap line; in canuing and evaporating it retains its sweetness and flavor to a high degree. 
Kausas. Originated at Lawrence, Kansas. It is healthy, vigorous and not subject to leaf blight; produces strong, healthy típs; fruit large, as fine a berry as Gregg and equally as good a shipper; ripens just after the Souhegan; very prolific.

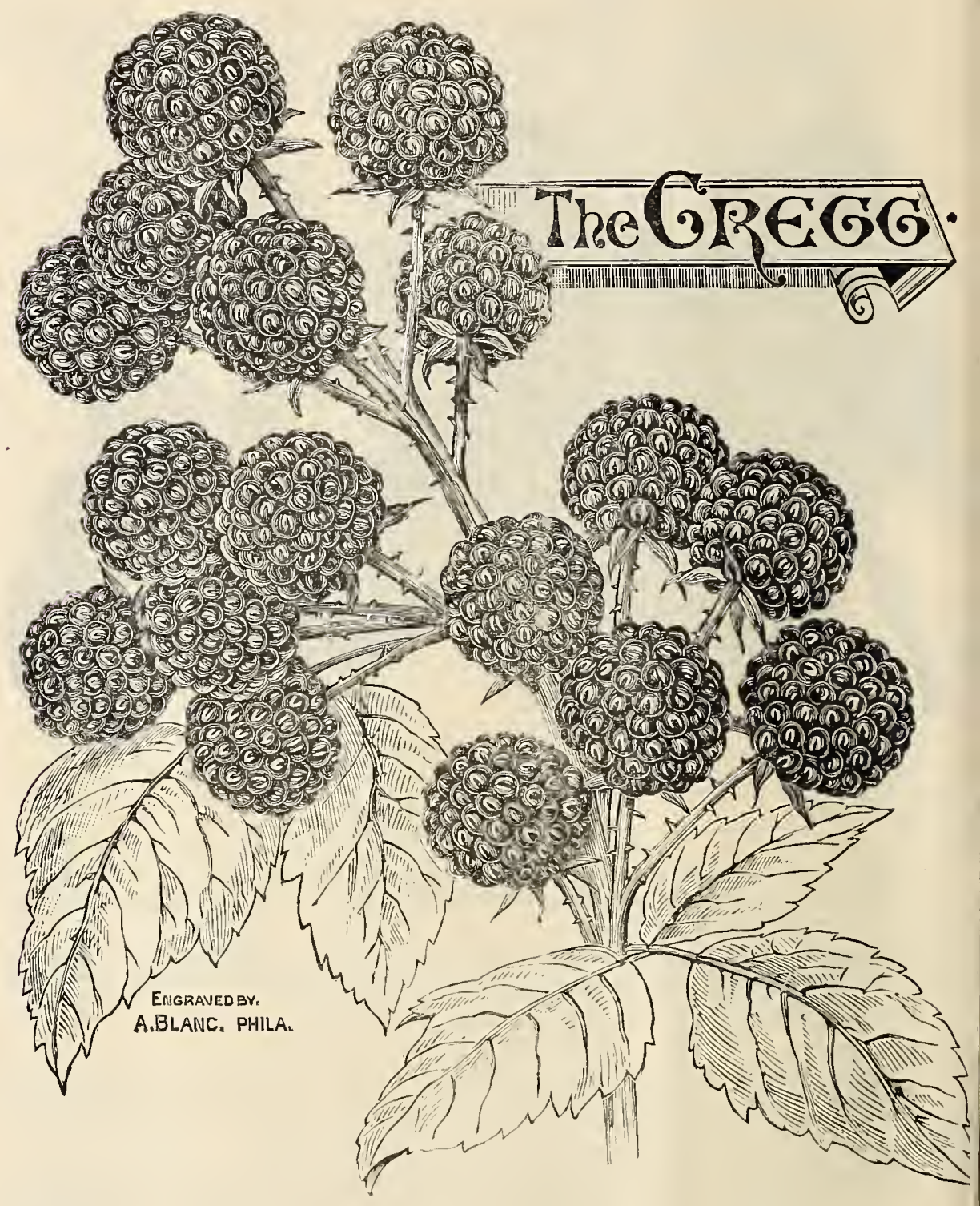

(y)

Mammoth Cluster. A well known old variety, yet retained for its high quality aud productiveness;

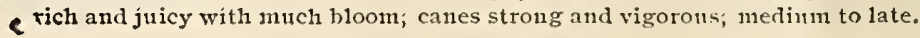


Ohto. Highly reconmended for canning or evaporating, and enormously productive; berry uot quite as large as Gregg, but of finer quality and the plants more liardy, and bears heavy crops annually; clained to be the most profitable of all.

-Palmer. Farly, ripeniug with soulhegan, but larger and unore productivc; it is said to bear larger erops even than Ohio; the canes are hardy and berries of good quality.

Shaffer's Colossal. Colossal, both in bush and berry; carries to market well; excellent to dry aud nusurpassed for eanniug; berry dark erimson in eolor and excellent in quality; a very valu. , able variety; does not sucker, but roots from tips like I3lack Caps.

Tyler. (Soulegan'. A leading early market varicty, ripening its entire crop in a very short time; mediun size, very black without bloom, flcsh firm and sweet; plant vigorous, strong, hardy.

\section{JAPANESE WINEBERRY.}

This is an entirely new, distinct and valuable berry. It belongs to the Raspberry family, is a strong, vigorous grower, attaining the usual hight of the Raspberry and is said to be perfectly hardy in all positions without protection. Its leaves are of the darkest green outside, and silvery white underneath. The young shoots or branches are covered with a reddish-browu hait or moss. The fruit is borne in large clusters, often 75 to 100 berries in a bunch. These berries are from the time of formatiou and loom, until they ripen, enclosed in a "burr," which is formed by the calyx eovering them entirely. When ripe the "burr" opens, exhibiting a large berry of the brightest, light glossy scarlet, or sherry wine color. The burrs and stems are covered with a heavy reddish moss LIKE A Moss Rosw BLD. The flavor of the fruit is entirely different from any other berry, being very sprightly, swect and juicy, having no disagreeable sour, but a delicate and luscious flavor peculiar to itscif, and superior to other berries. It comuluences to ripen early in July and continues in bearing for a long time. It is the most prolific berry known, the bushes being literally covered with its luseious fruit. It is propagated from the tips like Cap Raspberries and Dewberries, and can be increased rapidly.

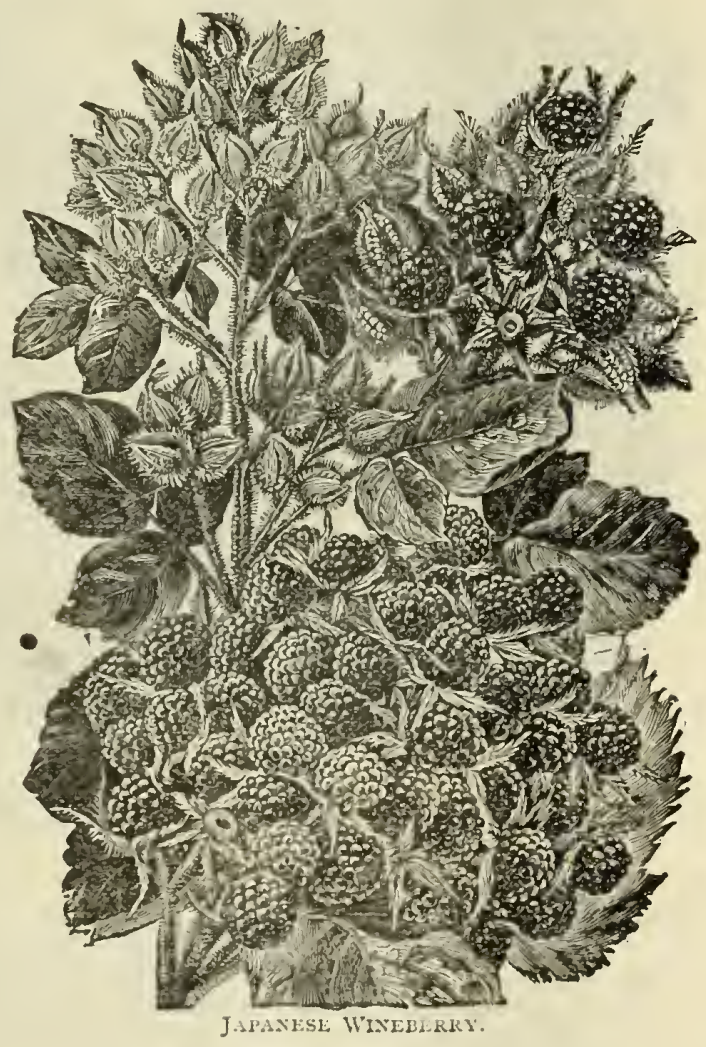




\section{GOOSEBERRIES.}

In order to produce large, abundant crops of Gooseberries it is necessary to manure heavily and prune closely. The English varieties do not require much pruning. Mildew is prevented by close planting and heavy mulching. Plant three to four feet each way.

bowniug. Fruit larger than Houghton; roundisl, light green, with distinct veins, skin smooth, flesh rathe soft, juicy and very good; vigorons and productive.

Honghton. A medium sized American variety, which bears abundant and regular crops, and never mildews; fruit smooth, red, tender and very good; very valuable.

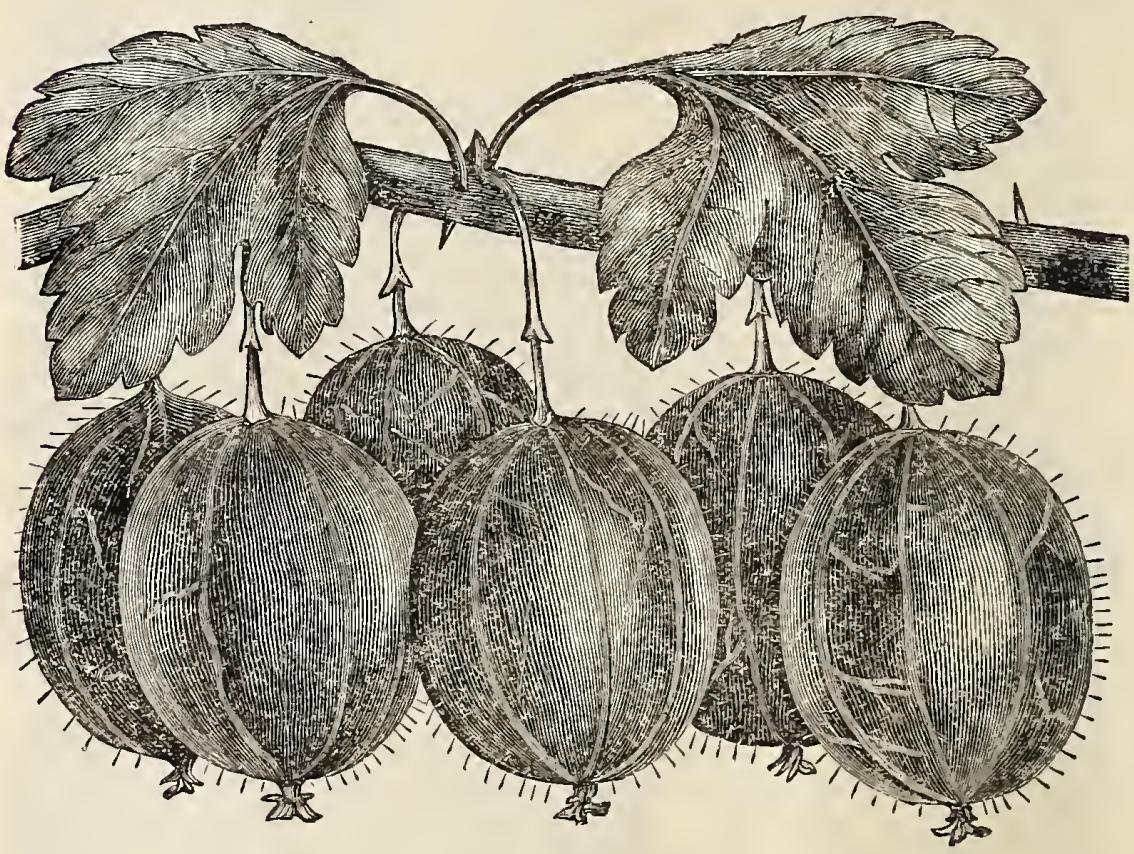

INDUSTRY GOOSEBERRY.

Smith's. (Smith's Improved). Large, oval, light green, with bloom; flesh moderately firm, sweet and good; vigorous grower.

Golden Prolifle. An American seedling of the English type said to be free from mildew; fruit large, deep golden yellow, very handsome and attractive; of excellent quality; hardy and a good grower.

windustry. The best English Gooseberry yet introduced; of vigorous, upright growth, and a greater cropper than any known variety, and much less subject to mildew than other English sorts; berries of the largest size, one and one-half inclies in diameter, and of most excellent flavor, both pleasant and rich; color when fully ripe, dark red. 
Currants do best on a cool, sheltered, moist location. Plaut about three feet apart. Rows four feet apart. Bcing perfectly hardy they can be planted in the fall and do not suffer injury from the winter. To destroy the currant worm, dust the plants witl White Hellebore when the dew is on; care should be taken not to breath the Hellebore as it causes violent sneezing.

Black Maples. Very large, some tines measuring lalf an incl in diameter; fine for wine or jellies.

Black Champion. Bumclies are very large and thic flavor of the fruit particularly dclicious; it hangs long on the bushes.

Cherry. The largest of all the red Currauts: berries sometimes neasuring lialfan inch in diameter, bunclies short.' plant very vigorous and productive when grown on good soils and well cultirated.

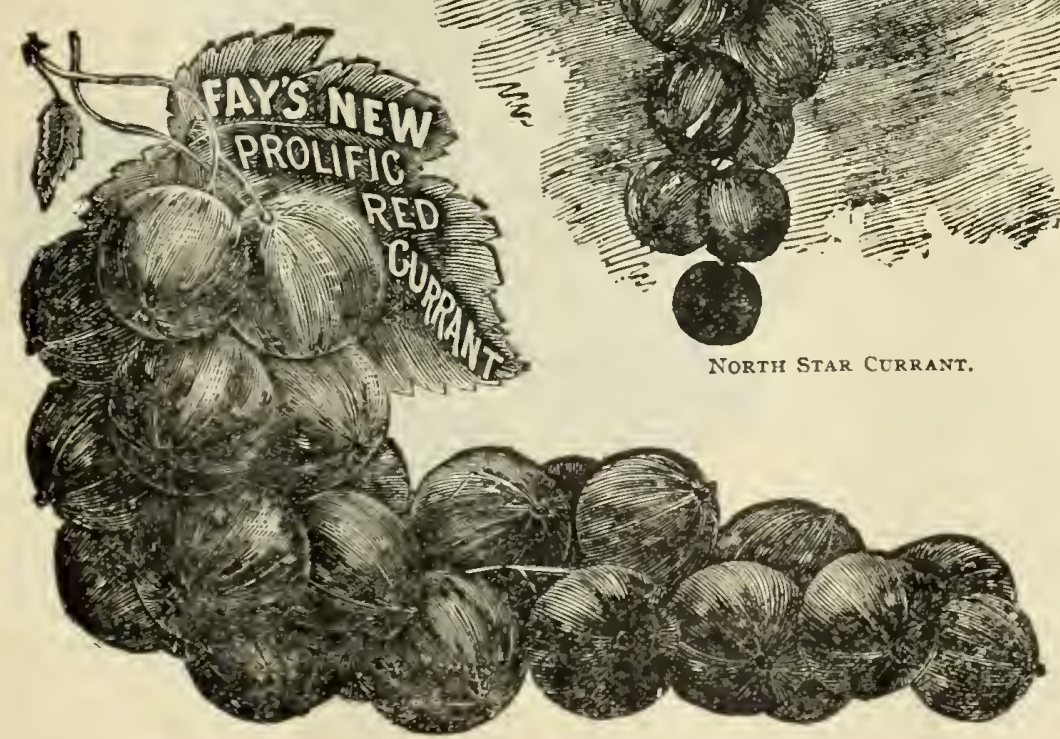

\section{CURRANTS}

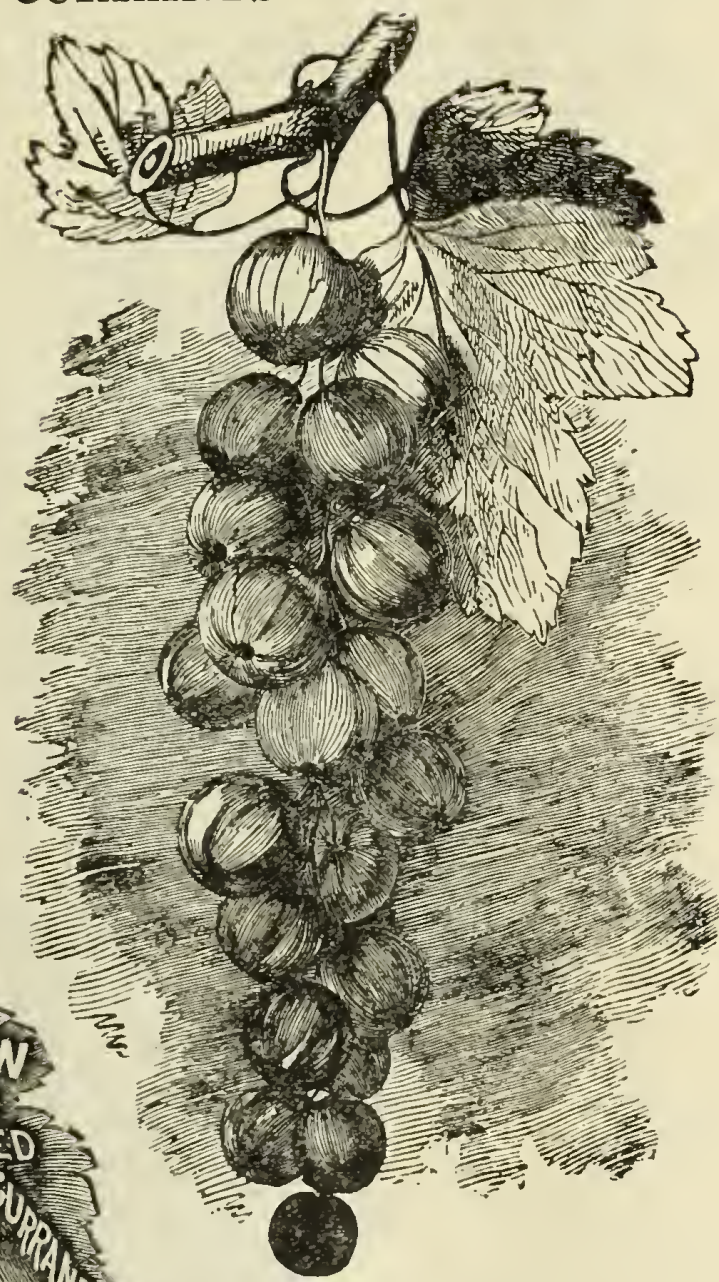

NORTH STAR CURRANT. 
Crandall. A native black seedling of the western wild Currant, and much superior to any of the named varieties yet introduced; distinct from the European black varieties and without their strong odor; wonderfully productive, a strong, vigorous grower, usually producing a crop next year after planting, large size, $1 / 2$ to $3 / 4$ inches in diameter; easily picked; can be shipped farther

$\checkmark$ and kept longer than any other small fruit; free from all attacks of insect enemies.

Fay's Prolific. Color deep red; a great bearer; stems longer than Cherry and berries hold thelr size to the end of the stem better; quality first-class, not quite so acid as the Cherry; claimed to be the most prolific and best of all red currants.

I a Versaillaise. Very large, red; bunch long, of great beauty and excellent quality; one of the finest and best.

Lee's Prolific. Black, large and of superior quality; vigorous and productive.

North Star. The average length of the bunches is four inches; the berries from a single bunch, thirty in number, placed side by side, touching, covered a line twelve inches in length; the fruit is superior, very sweet and rich in quality, firm, a good market berry, desirable as a dessert fruit in the natural state and nnequaled for jelly.

Red Dutel. The standard old variety; excellent and well known; a great bearer and a very profitable market sort.

Vietoria. I,arge, bright red, with very long bunches; 1ate; a good bearer.

White Dutch. An excellent and well known sort; good quality.

White Grape. Very large, yellowish white, sweet, or very mild acid, excellent quality and valuable for the table; the finest of the white sorts; very distinct from White Dutch, having a low, spreading habit and dark greell foliage; very productive.

\section{BLACKBERRIES.}

Culture. In field cu1ture plant in rows eight feet apart and three feet distant in the rows; in garden culture plant rows five feet apart and three feet distant in the rows. The pruning should be governed by the growth of cane and should be severe. Pinch back the canes in summer when three feet high, causing them to throw out laterals.

Early Harrest. This is one of the earliest Blackberries in cultivation; a compact dwarf grower.

*Erie. Enormously productive; perfectly hardy; very large and of good quality; ripens in advance of wilson Jr.; combines productiveness, hardiness, earliness, large size and good quality; five strong points of merit in its favor.

*Freed. Very hardy, pro. ductive and has never been known to rust.

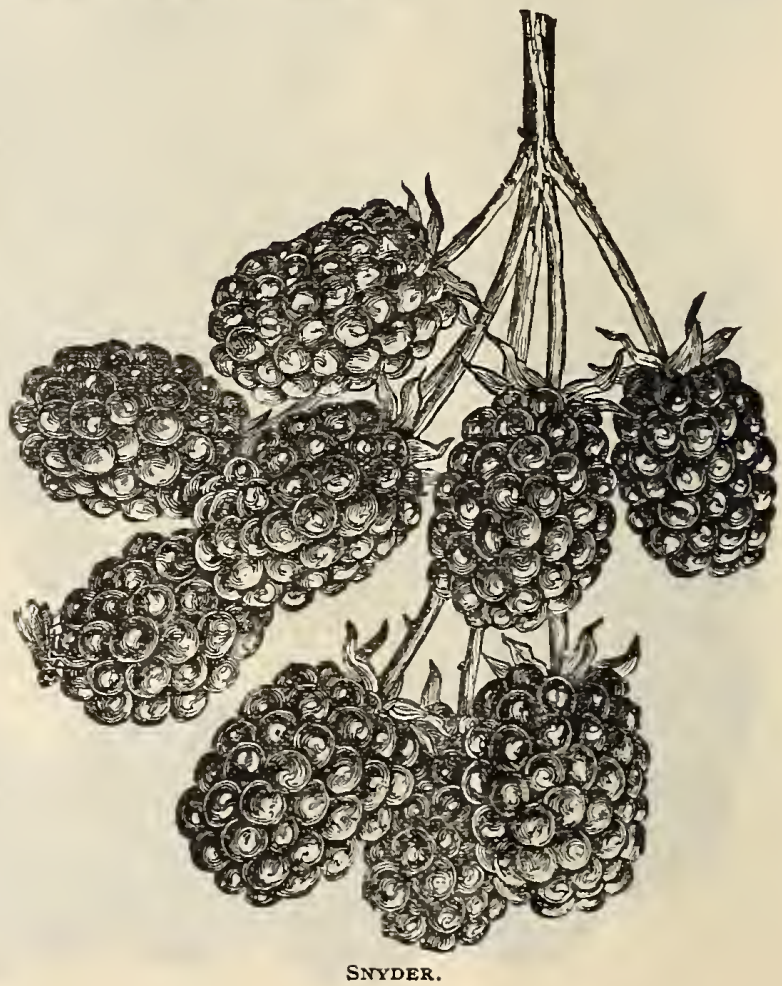


H.

Klttatlnuy. Large, roundish; conical, glossy black, juicy, swect; excellent when fully ripe; one of the most valuable sorts; rusts badly in some localities.

I.antou. Fruit is very large aud black, and of excllent quality; an abundant bearer.

Suyder. Extremely hardy, enormotsly productive, medium size; no hard, sour core; only half as many thorus as Lawton or Kittatinny, and thcy are short; most prolific Blackberry grown.

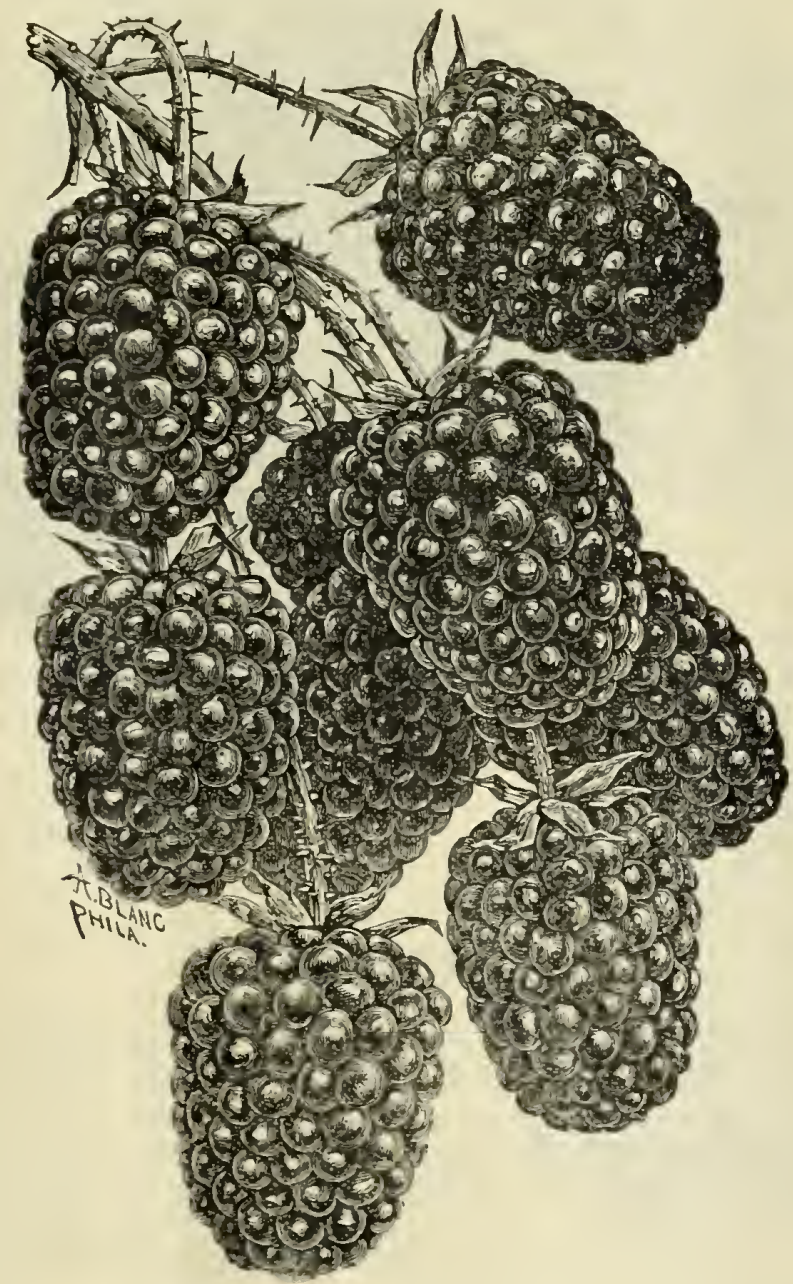

THE ERIE.

Stone's Hardy. Upright grower, very hardy; the bery is black and glossy when ripe, ank has a delicious favor; it commences to ripen its fruit abont five days earlier than the suyder, and continues bearing ten day's longer.

Tajlor. One of the largest Blackberries grown; fruit of the best quality, melting and without core; very productive, and as hardy as the suyder, which renders it very valuable.

Wilson's Fariy. Of good size, very early; beantiful dark color; of swcet, cxcellent flavor and 'very productive; rigens the whole crop nearly together; needs sume grotcction in wintcr. 
Wachnsett Thornless. Fruit of unediun size, oblong, oval, moderately firm, sweet and good; it is a good keeper, ships well, and valuable as a market berry; hardy and almost free from thorns.

Wilson's Juntor. The largest and most productive early Blaekberry known; produces its fruit iu immense clusters; ripens evenly; becomes sweet as soou as blaek; holds its color well after being picked, and brings the highest price in the market; needs protection in winter.

DEWBERRY.

Lucretia bew berry. Fruit very larse, luseious aud handsome; perfectly hardy, a strong grower and enormously productive; a superb and very profitable market fruit; the vines should be allowed to rcmain on the ground during the wintcr, and staked up early in the spring.

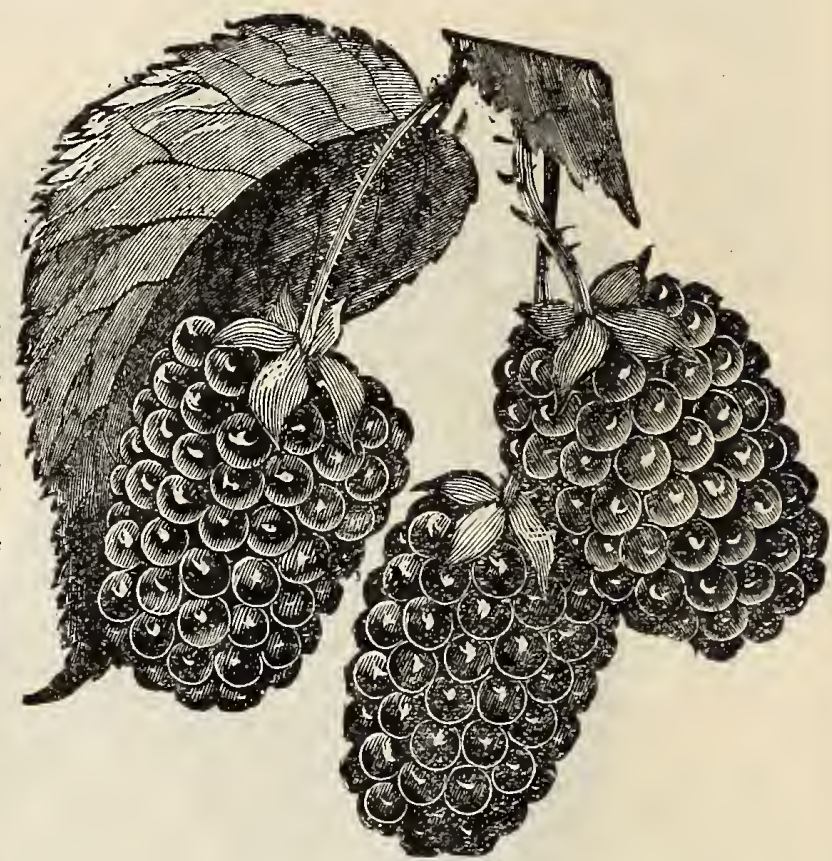

LUCRETIA DEWBERRY.

\section{STRAWBERRIES.}

Directions for its Culture. It is supposcd that those who are entering into field culture of the Strawber:y for marlet purposes without practical expericnce will harcily dejerd on the brief directions that can be given here; fuller instructions will be freely given upon application.

The Soll and its Preparation. The ground should be worked eighteen or twenty inches deep and be properly enriched as for any garden erop; drainage is nccessary in very wet soil.

Cultivation. For family use, plant fiftccn or eighteen inehes apart each way, and after a few strong plants have set from runners then pinch off all runners as fast as they appcar; keep the ground free of wccds, and frequently stirred with a hoe or fork. Plants trcated in this manncr will produce more erowns and therefore yield double the amount of well developed fruit than when runners are left to grow.

Covering in Winter. Where the winters are severe it is well to give the ground a light coving with coarse straw or litter. This covering should not be placed on until the ground is frozen. Fatal errors are made by putting on too much and too early. If eoarse straw is uscd it may be left on until the plants have done fruiting, taking care to open it up around the plants early in the spring, so as to give them plenty of sunlight and air.

The blossoms of those marked with a letter (P) are destitute of stamens and are termed pistillate, and unless a row of a perfect flowering varicty is planted at intervals not exceeding every third or fourth row, they will produce imperfect fruit, and but little of it; but when properly fertilized, as a rule, they are more prolific than those with perfeet flowers. 


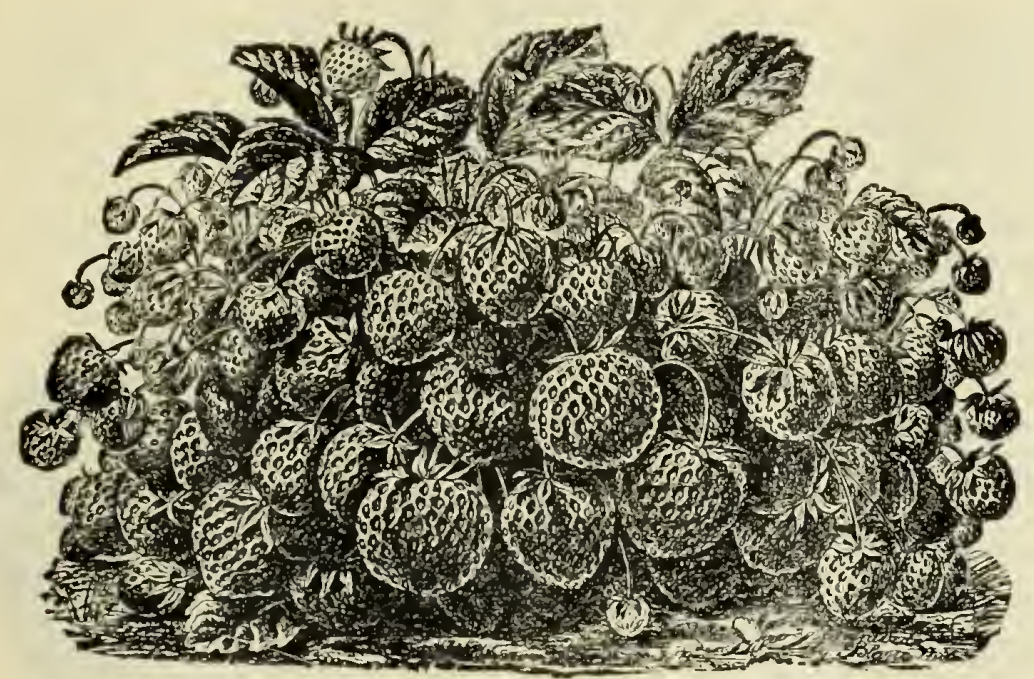

STRAWBERRY PL.NTT WITI RUNNERS CUT.

"Hubach No.5. (P'. A wonderful berry iu vigor of plant and yicld of fruit even under eareless en 1ture. The fruit is in many instances enormous, and the avcrage is large and handsomc. It is exceedingly productive and very valuable for a near by market. Midseason.

Crawford. From Ohio, and the originator thus describes it: "The plant is very large and stocky, clark green and frec from defects. It has a perfect berry and is a good bcarer. The fruit is large to very large, somcwhat irregular at first but never coxcombed. Color bright glossy red and lighter within. The flesh is firm and of cxW cellent quality:"

Claderella. A splendid early variety; berries large, conical, regular, bright glossy scarlet, firm, of excellent flavor; plant unsually vigorous and 6 healthy.

Captain Jack. A most vigorous grower, healthy and productive; berries large, haudsome aud solid.

Cumberlaud Triumph. A uagnificent variety; berries immense; fine, perfect form, and of fine flavor; plant very vigorous and moderately productive.

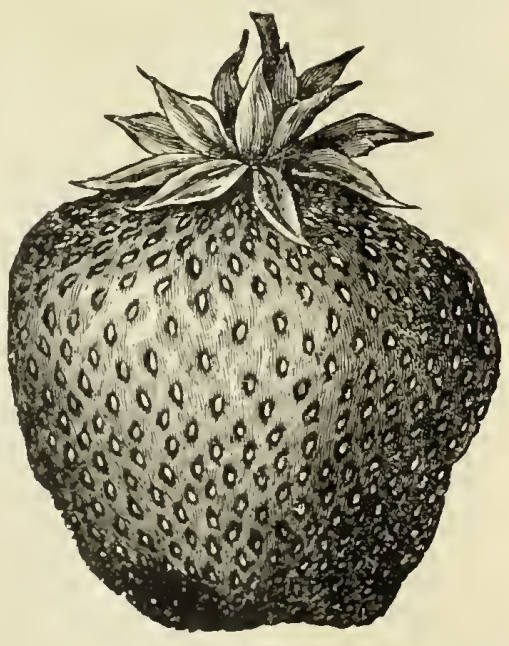

BLPBACII No. 5 .

Crescent Secdling. (P). Medium size, bright light searlet, not very firm; continues a long time in fruit; plant very vigorous and hardy, and will produce good erops under greater neglect than any other Strawberry, and is a good paying variety for both family use and market.

Charles Downing. Large, conical; crimson; flesli firm, of fine flavor and good quality; plant bealthy, vigorous and productive.

Eureka. (P). Plant vigorous, of medium size, very prolifie; large berry, of good quality, firm and of good shape; medium to late in ripeniug. 
YI: ,

Pr. Profitable by reason of its produetiveness and earliness, but it is hardly firm enough for distant shipment; rcquires dccs), heavy soil; plant e*ececingly vigorous and healthy; fruit large, handsome and good, though not of the best quality; rather long in shape and of a bright glossy crimsou; early.

Jewell. (P). Season medium; size large; eolor bright red, ehanging to erimson when ripe; won derfully produetive; very firm.

Jessie. The plant is a stout, luxuriant grower; foliage light grcen, large and elcan; the berry is very large, eontinuing large to the last picking; it is a bcautiful color, fine quality, good form, quite firm, laving been shipped 600 miles in good conditiou.

Jersey Qucen. Berry is very large, eolor a fine shade of searlet; flesh firm and melting; full of rich vinous juice, with a deliciously spicy aroma; late, productive.

Lady Rusk. The fruit is of large size, severa! days earlier than the Crcscent, and is its superior in every respeet, holding size weli throughout the entire picking, and above all, one of the most productive vorieties.

Hincr's Prolific. Somewhat similar to Charles Downing, but larger; darker in eolor; berries are of irregular shape, ridscd and furrowed, of a mild, pleasant flavor; very produetive; midseasoll.

May King. Strongly resembles Crescent, of whieh it is a scedling, both in fruit and plant; produetive; firm; berry of the eolor and size of its parent, and of the same bright, showy appearance; valuable for market.

Manchester. (P). Size large, color scarlet, flesh pink, firm but melting, with a rich sub-acid juice and a decided aromatic flavor; robust and very productive; quality very good to best.

Michcl's Early. Miehel's Early is the earliest of all good and reliable Strawberries; it is two weeks earlier and is as productive as the crescent; a perfect bloomer; size above medium to large and very uniform; color beautifuily scarlet; shaped haudsoucly conical; quality very fine; pronouneed by all who have tested it to be the finest-possessing the flavor of the wild Strawberry.

Parry. Seeding of Jersey Queen; the fruit is uniformly large in size, beautiful, moderately firm and of good quality; plant strong, vigorous and productive; requires good soil; carly.

*Parker Earle. Produced in Texas in 1886; plant very robust, strong penetrating roots, a model in makeup; endures well the long, hot, dry summers of Texas and in Michigan and New York stands the winter eold equal to any other variety; euormously produetive, having for two years in succession, on the same bed, in light sandy soil, fully developed a erop at the rate of 15,000 quarts to the acre; flowers perfeet, protected from late frosts by abundant leaves; trusses strong, long and large; berries regular, eonical with short neck, glossy, searlet crimson, firm, no hollow core, seeds golden; it shows well several days after picking, carries fincly in loug shipments, presents an attractive appearance in the crate and brings the highest price in market; season early to mediuu.

Sucker State. Fruit medium to large; regular shaped, conical; color somewhat like Cumberland Triumph, but darker and more brilliant; decidedly one of the finest market berries.

Sharpless. This is one of the very best varieties in certain soils; large in size, delicious flavor, good bearer, bright eolor; specinens exhibited weighed $1 \frac{1}{2}$ ounees, and measured seven inches in circumference.

Warfleld No. 2. (P). Quality pleasant, sub-aeid, good; the plant is a vigorous grower with bright healthy foliage; early.

Windsor Chief. (P). A vigorous grower, with liealthy foliage and immensely productive; fruit of laige size to the end of the season. 


\section{ASPARAGUS.}

To preparc a bed for planting, the soil should be dng deeply and well mixed together with well rotted manure or compost. Plant in rows two feet apart. In the rows the plants shonld not exceed a foot apart, and planted abont four inches deep. Cover on approach of winter with manne, and fork the bcds over lightly carly in the spring.

Conorer's Coloxin. A mammoth variely of vigorons growth, scuding $n p$ from fifteen to twenty spronts each year, from one to two inches in diancter, color deep green, and crown very close.

Palnetto. It is carlier, a better yielder, more even and regular in its growth and in quality equal to that old favoritc, conorer's Colossal.

\section{FIGS.}

Figs may be grown as bushes in the garden, in the Northern States, if they are taken up annully, the first week in November, with a ball of carth attached to the roots, and placed in a cellar till abont the middle of May, when they slionld be taken out and replanted.

Brown Turkey. Brownish purple, large, rich and cxcellent.

Black Ischia. Meclium; skin decp purpic; flesls swect, ricl.

Celestial or sugat. Fruit sma11, but very swect.

\section{RHUBARB, OR PIE PLANT.}

This deserves to be ranked among the best early vegetables in the garden. It affords the earliest material for pies and tarts, continucs long in uhe and is valuable fot canning. Make the border very rich and decp.

Linnans. Ixarge, carly, teuder and fine; the very best of all.

Victoria. The best for market becanse of its ginnt growti.

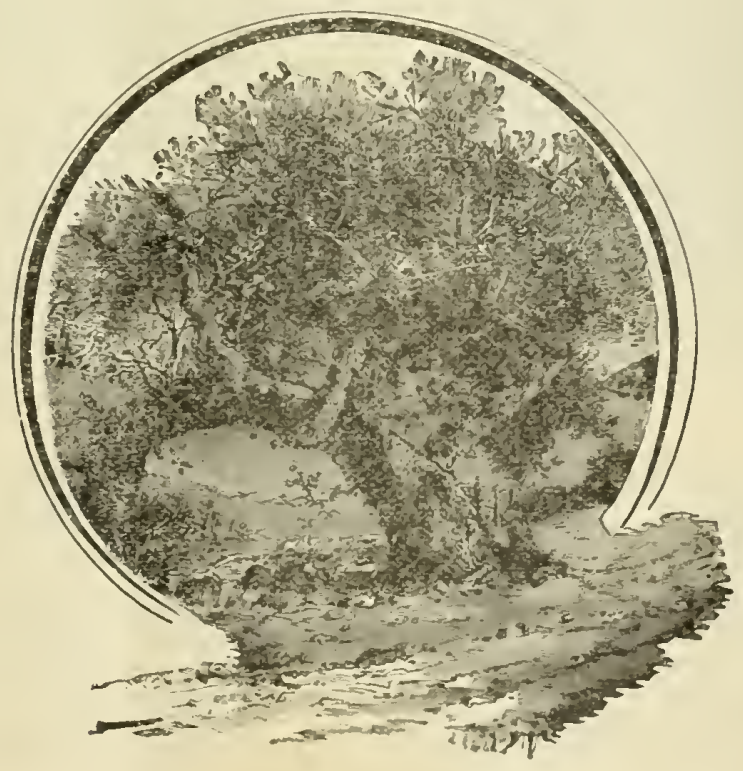




\section{ORNAMENTAL DEPARTMENT.}

Suggestions to Planters. The extremes in temperature in this country are so great and the changes ofteu so sudden that it is safe only to plant the most hardy ornamental trees and shrubs. Those varieties that will grow in the nursery when young without protection in winter may be regarded as safe to plant in parks and extensive grounds and in lawns and sinall places. Yet a few of the most beautiful sorts are not perfectly hardy and will be greatly benefitted by some protection during severe winters. A judicious selection from the many varieties given in this catalogue will enable the planter to accomplish his desire in securiug that which will give him satisfaction both in hardiness and in effect.

For Parks and Extensive Grounds. In making selections of trees for this purpose there can be no difficulty, as there will be places for some of all the popular strong growing sorts as well as many places for the smaller and more oruamental varieties, which are frequently planted in groups, and when by a proper selection so that there may be a succession of flowering and a var: ety of coloring of the foliage in the autumn, they make a picturesque appearance. But it cannut be too strongly urged upon planters the importance and value of flowering shrubs for effeative masses and groups. All of the hardy varicties, such as Althea, Forsythea, Weigelias, Calycanthus, Deutzia, Snowball, Hydrangia, Lilac, Syringa, Japan Quince, Fringe-purple and white-Daphine, Thornes, Almonds, Anemone, Pxones, Phlox and mauy others whell arranged either in groups or properly distributed produce a magnificent effect, and what grand masses of bloom can be liad throughout the scason by proper use of the various families. The purple and variegated leaved trees and shrubs may also be plauted in such a manner as to afford a rich and striking contrast.

For Lawns and Small Places. A little more care may be taken in making selections for this purpose, although the selections will depend very much on the size of the ground to be occupied. Where only a few trecs and shrubs caul be planted, the medium or small growing sorts, 911. those that display the finest appearance both in foliage and flowers should be used. While on larger places a more extensive assortment can be plauted.

Evergreens. It is unnecessary to argue in favor of the planting of this noble species uf sruamental trees. Their stately appearance have too often caught the eye of the admirer of beautiful laudscapes, parks, lawns and home places and left its lasting impression on the mind, to be forgotten or overlooked in arranging the planting of even small grounds. Nothing is more beautiful than a well arranged group of select Evergreens, and when properly distributed singly over the grounds their appearance adds greatly to the scenery.

When and How to Plant, Prune, Etc. The same directions as are given in the front pages of this catalogue will apply to ornamental trees and shrubs. Spring is the best time to plant Evergreens, yet autumn planting is attended with success when properly protected during the winter. Little pruning is necessary on the Pines, Spruces, etc. It is necessary to shorten in to thicken the growth and preserve the shape and this should be done just before the buds begin to swell in the spring. Arborvitæs, Cypress, Junipers, Cedars, etc., can be shortened in or sheared any time during the growing scason. Too much care cannot be takell to keep the roots of Evergreens from being exposed to the asmosphere while out of the gronnd, and a protection the first year from the sun and winds by a lattice work of thin lath will aid in securing the life and growth of many Evergreens.

\section{DECIDUOUS TREES.}

All,ANTUS. (Tree of Heaven). Glandulosa. From Japan; a lofty, rapid growing tree, with long, elegant, feathery foliage, exempt from all diseases and insects; one of the most distinct of ornamental trees with pinnate foliage.

AIDER (Alnus.). European (Glutinosa.). A tree of rapid growth, suitable for damp soils, but thriving well everywhere.

Inperial Cut-Lented (Lasciniala Imperialis). A very striking and beautiful tree, with delicate and beautiful cut leaves; hardy and of vigorous growth; one of the fillest cut-leaved trees in cultivation.

Iascinista (Cut-Leaved Alder). Fron Northern France; a very ornanental variety, with lark green and deeply serrated foliage.

ALMOND. Large Double-Flowering (Amygdalus). A beautiful little tree which bears a profusiou of donble rose-colored blossoms in the early spring. 
ASIl (Fraxinus). European Excelstor. A lofty tree, with piumate foliage and spreading head.

Gold Barked (Aurea). Growth irregular; very ormaneutal in winter.

Flowering (Ornus Europans). A very ormamental dwaif tree; flower fringe like, greenish white, early iu Jume; in large clusters on end of the branches.

Willow-Leafed (Salicifolin). A rapid stout growing tree, will narrow, wavy leaves; very ormanental.

Ancuba-Ieared Ancubufolia'. A fine tree with gold blotched leaves.

American White. A rapid grower aud valualse for plantiug in the street or in parks; uay be exclusively plauted for timber.

BELCII Fagus). Iachta (Cut-Leaved). Foliage deeply and fuely cut.

Purple-Leared (Purpurea). A rcuarkable species with deep purple foliage, changing to greenish purple in autumu; a very striking contrast with oramental trees.

Fern-Ieared Heterophyllat. Of elegant round habit, and delicately cut feru-like foliage; one of the finest lawn trees

Imerican (Fagus ferruginea). Our native sort, well known; one of the nost picturesque of rcuud-lieaded trccs.

HIRTH (Belula). European White Belula alba). A well known tree, witl graceful airy foliage, aud silvery white bark; very dcsirable for the lawi, either as a single specimen or in contrast with other trees in a group.

l'urple-Leared (Folius furpureq). A very desirable novclty; with the lubit of the Birches, it lias beautiful purple foliage, as dark as that of the Purple Beech.

l's ramidalis. Silvery wlite bark, with elegant p, ramidal habits, like Lombardy Poplar; not entirely hardy while young.

Turopean White. Cut-Leaved (see Weeping Trees'.

CATAM.1. Bungei. This on its own root is a dwarf Cata:pa, a close, compact shrub, absolutcly healthy, liardy; its branches are $n$ merous and shcrt, the broad leaves lay as shingles on a roof, making a dense shade, aud when worked eight or more feet high, makes the umbrella-shaped top tree, equal if not even nore symmetrical than the fanious Umbrella china trce of the South; being thus worked it has gtowll fiv and one-half feet in dianeter in two years.

Speciosa. A variety originating at the West, more

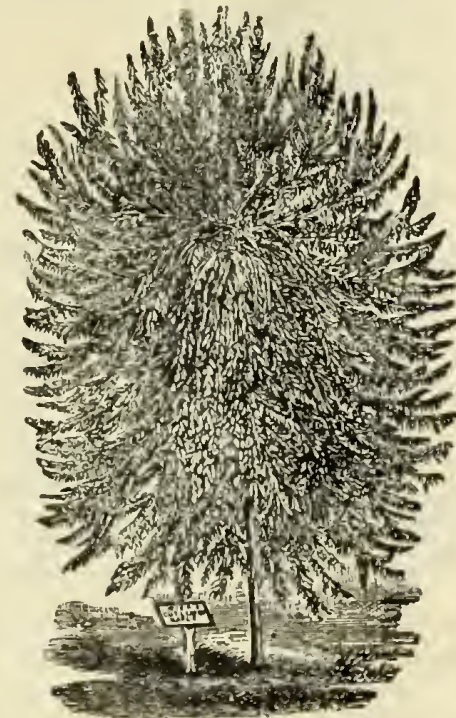

WILR'S CUT-LEAVED MAPLE. (See page 49.) 13pright and symmetrical in its growtl than the common Catalpa, and blossoms two or three weeks earlier. Vcry valuable for timber, fence posts, railroad ties, etc, possessing wonderful durability; a very ornamental and valuable tree.

Syringafolia. A native of the South; a rapid growing beatiful tree, with large heart-shaped lcaves and pyramidal clusters of white and purple flowers a foot long. Late in June.

Teas' Japanese Ilybrid. A cross betwecu Speciosa aud Kaempferii; it has large huxutiant foliagc, and large handsone white flowers with purple dots and a touch of yellow around the throat, which have a pleasant delicate fragrance; when in bloon presents a magnificent appearance. In rapidity of growth it rivals the most luxuriant trces; perfectly hardy.

CHLitict. Inerican Castanea Americana). A well know forcst and nut-bearing tree, of great value for ornancutal purposes. This trce is now receiving grcat attention, and being widely and extensively planted for profit as well as ornament.

C.I RESS. Decidnons or Southern Cypress. A locantiful, stately tree; with small, elegant, ewe-like foliage; very hatdy aud othamental. 
CHER ax. Flore Alba Pleno (Large Double Flowering Cherry). At the period of flowering a remarkably bcautiful and attractive tree; the flowers are so unmerous as to conceal the branches and to present to the eye nothing but a mass of bloon, each flower resembling a miniature white rose; a valuable variety deserving wide dissemination. May.

DOGWOod. Cornus Florida. An American species of fine form, growing from 16 to 25 feet high; tl:c flowers are produced in tile spring before the leaves appeat, are from three to three and a lialf inches in diameter, white and very showy, resembling the Clematis flower somewhat; the foliage in autumn is of a decp red, color, rendering the tree one of the most beautiful objects at that season.

Red Flowering ( $C, F . R$ uba). Tree in habit of growth not unlike the grand white flowering variety; flowers are a rich rosy red and several inches across, while the foliage assumes a crimson color at an earlier stage; the finest of our native flowering trees.

ELM (Ulmas). American White (Americana). The noble drooping, spreading tree of our own woods; one of the graudest of park or strect trecs.

Campestris (English). More upright and compact hasit than American; also the lcaves are swaller and inore numerous.

Purple. A beautiful variety, leaves of rich purple color when young.

Scotch or Wych (Montana). A fine spreadiug tree of rapid growth; foliage large.

Subrosa (Cork-barked). Bark becomes corered with a fine dense cork with dcep fissures.

horse ClestNut (Esculus). Nlba Plena (Donble Whitc). A superb variety with large spikes of handsome double flowers.

Common or White Flowering (Hippocastanum). A very bcautiful well known trce, with round dense head, dark green foliage, and an abundance of showy flowers in early spriug. As a single lawn tree or for street it has no superior.

(ilabra (Bnckeye). Similar to the common with small fruit and yellowish nowers.

Red Flowering (Rubicunda). Not so rapid a grower as the white, foliage of a datk green and blooms earlier. A very showy tree.

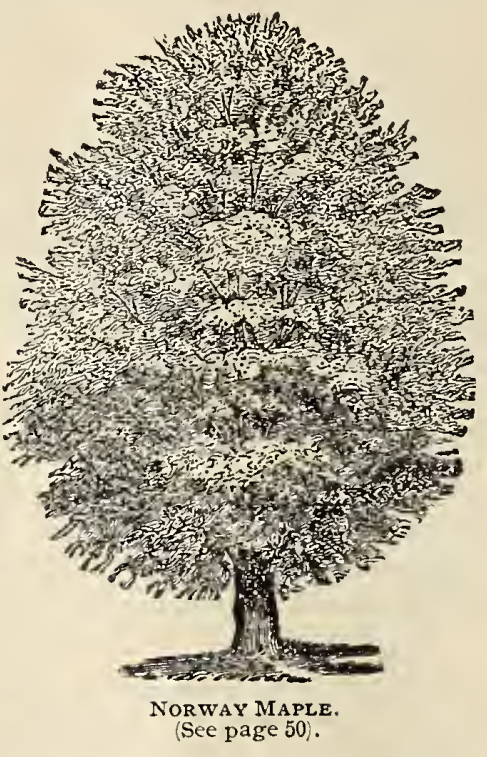

HORXBE. M. Carpinus. A small sized tree somewhat resembling the Beech; rery hardy and quite ornamental; makes an excellent and very ornamental hedge.

JUDAS TREE or IRED BUD (Cercis). Anericau (Canadensis). A very ornamental small tree, native of the Western States, which in the early spring, before the leavcs appcar, is covered with delicate pink flowers. "Nothing can be more beatiful in April or May than a large round headcd Red Bud covered with its beautiful flowers, before the bursting of a single leaf."

furopean liose Colored (Silisquastrum roseum). Similar to the preceding, but with darker foliage and deeper colored flowers.

KETTCKY COFFEE TREE. A unique and beantiful tree; leaves in tufts, flowers white, borne in loose spikes in early summer, succeded by brown pods which contain six or seven large gray seeds.

KLLREUTERIA. Puniculata. Fron China. A lardy small tree with fine lobed leaves and large panicles of showy golden flowers in the lattcr end of July; leaves change in autumn to a fine yellow. One of the most desirable trces, particularly valuable for its brilliant golden blossoms, which are produccd so late in the season when few if any trees ate in bloon.

LARCI. Europenu. A beantiful trce; foliage is of agreeahle light green hie, soft and graceful; the branclies are drooping and slender, leaves needle shaped, like a fir tree. 
LABURTCM. English or fiolden Chalu. One of the unost ormamental of small trees, with smooth shining foliage aud bright yellow pea.sluaped blossoms, produced in beautiful hanging clusters.

LIOIIIIMIBIR. Snet fium. One of the finest American trees; of medium size and moderate growth, form round headcd or tapering, leaves resemble somewhat those of the Maple, but are star-shaped and of a beatiful light green color in sumner, turuing to deep purplish crimson in antumn; bark corky; beautiful in all stages of growth, it is particularly landsome and striking iu anturnn.

I.tCIST Robinia). Black, or Yellow Locust. A native tree of large size, rapid growth, and valuable for sliade as well as quite ormanental. The flowers are disposed in long pendulous racemes, white or jellowisli; very fragraut and appear in June.

lloney Locust. Three-Thorned Aeacia (Gleditschai Triacanthus, A rapid growing trec; delicate foliage, of a beautiful, fresl, lively greeu, and strong thorus; uakes an exceedingly haudsome, impenctrable aud valuable hedge.

Rose, or Ioss Locust. A native species of spreading irregular growt1, with long, elegant clusters of rose colorcd fowers in June and at intervals all the season.

Lixlex. Ameriran Businood \{Tilia Americana〉. A fine uative tree, with large leaves and fragrant flowers.

Europenn (Tilia Europea). This variety gencrally grows regular and conical, and when plauted by itself it dcvelops finely; in such a situation with its lianclies swceping the ground, it bccomes one of the most beantiful objects which a siugle trce is capable of forming.

White or Silrer-Ieared (Argentea). A landsome, vigorons growing tree; large leaves, whitisln on the nuder side, and having a beautifnl ap, pearance when ruffled by the wind; one of the best.

lahbru (Red-twigged European I,inden'. A fine variety with blood-red branehes.

M.MPOLI. Aruminata (Cucumber Tree'. One of the largest growing of the spccies; it forms a fine pyramidal-shaped tree; the flowers are jellowish white, medium sized, appearing in June. The fruit when green resembles a small cncumber; but when ripe it is a dcep scarlet.

Conspicua (Chinese White Magnolia). A high prizcd species on account of its large wlite flowers, which come before the lcaves in spring.

flauca (Sweet White Magnolia). Fiverywhere estcened for the delicions fragrance of its white flowers, which are produced through May and Junte.

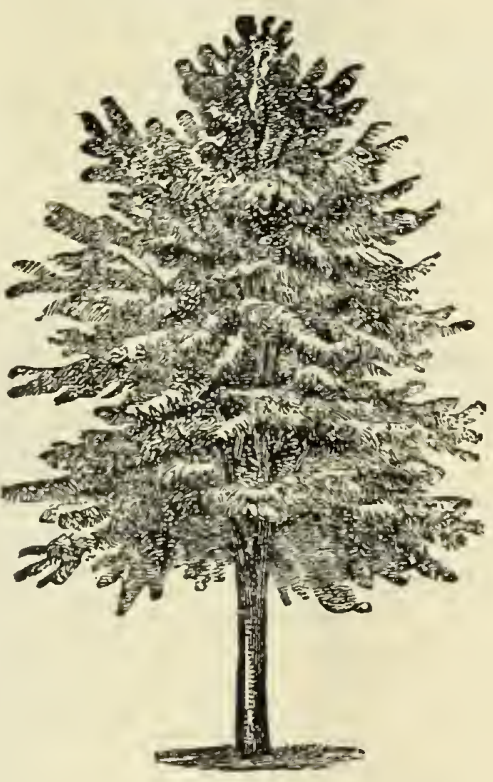

SII.VI:R-LEAF MAPLE. See page 50 .

Purpurea (Purple Magnolia). A large, shrub-like species, prodncing light purple blossoms very early in spring.

Trlpetala (Unihrella Tree). One of the most estecmed and useful tiees; it forms a small sized tree; has large, fresh, green looking foliage, large, white flowcrs, and brilliant scarlet fruit in August.

MAPLW (Acer.) Aal Learel (Vegundo'. Box-Filder. A fine, rapicl growing variety, with handsome, light green permeated foliage and spreading head; very hardy, excellent for avenues.

Wier's Cut.Leaved (Laciniala). A silver Maple with remarkable and beautiful dissected foliage. Of rapid growth; shoots slender anil drooping, giving it a very graceful appearance; should be in every collection. (Sice illustration page 45 .

Syrauore (Pseuto Plalanus). A largc, noble variety, witl spacions hearl aud deep green foliagc; a free grower and very desirable as a shade tree. 
Norway (Platanoides). A foreign variety, with large broad leaves of a deep rich green; probably the best Maple in cultivation. (See illustration page 48).

Purple-Leaved (Purpurea). One of the most beautiful and distinctly marked of a11; leaves pur. ple red, particularly on the under side; a rapid, strong grower; hardy.

Schwedlerii (Schwedler's Maple). A beautiful variety, with young shoots and leaves of a brigh. purplish and crimson color, which changes to purplish green in the older leaves.

Scarlet $(R u b r u m)$. A rapid growing tree with red flowers very early in the spring.

Silver-Leaved (A. dasycarfumi. Of rapid growth; of great value where a rapid growing tree is desired; very hardy and easily transplanted; a favorite street or park tree. (See illustration page 49).

Sugar or Rock (Sacchari. numl. A very popular American tree, and for its stately form and fine foliage, justly ranked amoug the very best, both for lawn and avenue.

מOUNTAIY ASH. European. (Sorbus aucuparia). A very bcautiful tree of medium size, with an erect stem, smooth bark and round head: covered during the fall and winter with bright scarletberries; universally admired.

American. A tree of rapid, but coarser growth than the European variety, pinnate foliage.

Oak-Lcaved (S. quercifolia). A handsome tree of erect habit and rich grecn foliage, deeply lobed; very hardy and desirable.

MULBERRY. White (Morzes alba). A small sized tree of slcnder but very rapid growth; produces ft ti it of pinkish white color.

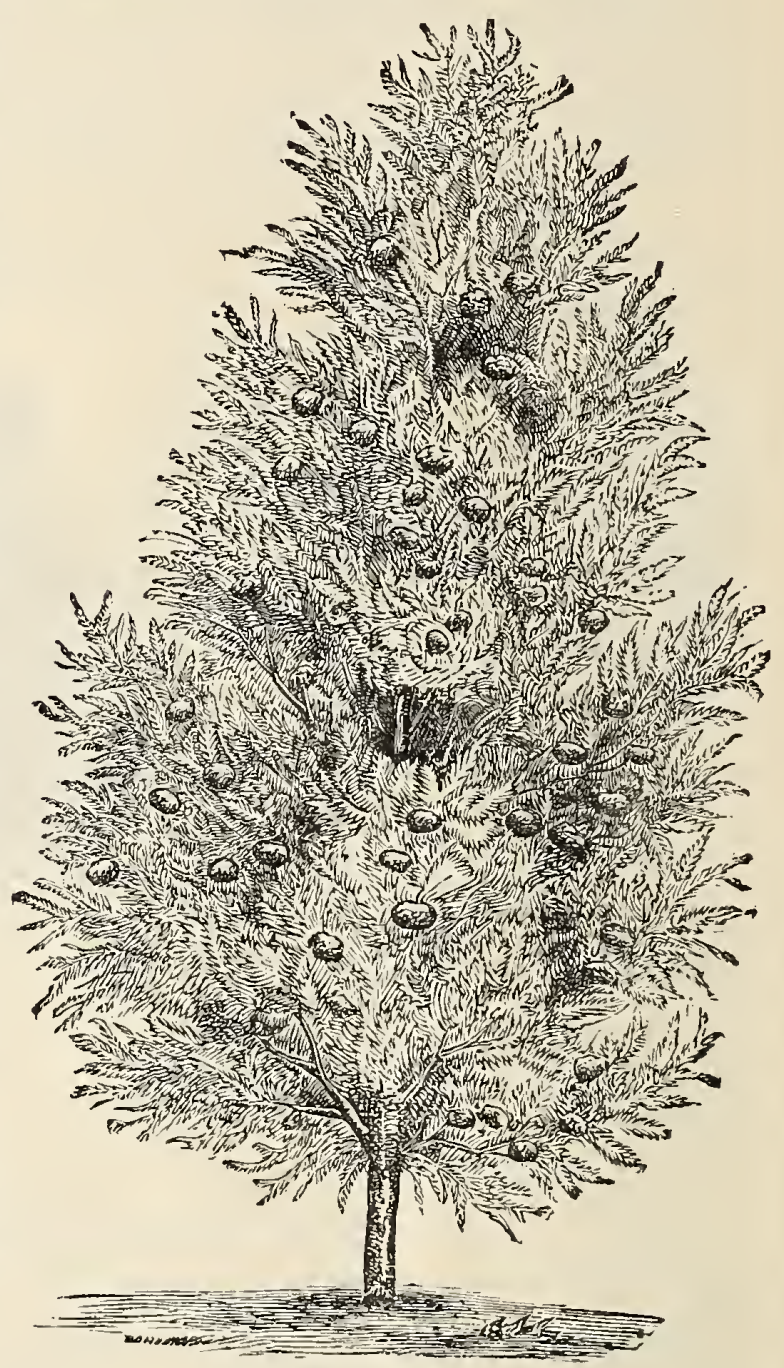

Europhan Mountain Ash.

Russian. Similar to the white; very hardy.

Tea's Weeping Russian. (See Weeping 'Trees). 
OLIVE. Russian. An ormamental tree of special value; attains a height of thirty feet or more; bark and leaves light green when young, bark becoming darker as the tree grows older, and the leaves more silvery wlite; blooms profusely in $\mathrm{J}$ une in small racemes three inches long and their fragrance decidedly sweet and spicy; au excellent lawn trce.

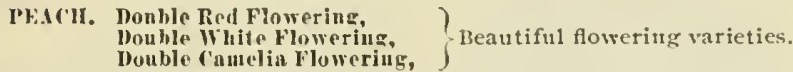

Blool Leared. A variety with foliage as dark as tie l'urple-leaved Beech-a very curious tree.

*Plix. Purple-Leared Prunus Pissardii). Vcry remarkable and beautiful, with black bark and dark purple lcaves; remaining very conslant until late in the fall; the new growth is especially briglit; the fruit is also red and saicl to be very good; a great acquisition.

PERSIMON TREF Diospyros l'irginica'. A small native tree with pleasing, shining foliage, aud well known frut.

PoPldR. Silver-Ieared Abele Poyulus alba'. A tree of remarkably rapid growth; at a distance the white uuder surface of the lcaves, turned up to the wind, gives it somewhat the aspect of a tree covered witl white blossous.

Balsam (P. balsamifera). Balm of Gilead. Of very rapid growth; large glossy leaves.

Carolina Poplar. Of good form and robust growtl, and desirable where a very large tree is required.

Lombardy $(\Gamma$. Fastigata or dilatafa). Well known for its erect, rapid growth and commanding form; very desirable in large grounds or along roads; indispensable in landscape gardening to break the ordinary and monotonous outlines of most other trees; if cut back to within eight or ten feet of the ground when three or four inches or more iu diametcr, it makes a beautiful round-headed, symmetrical tree.

SALISBurl. Maiden Hair Tree or Gingko'. Aliantifolia. A singular and beautiful tree; foliage yellowish grcen, curiously lobed and marked with delicate hair-like lincs.

SrCAMore. American Plane or linttonwool. A well kuown tree and one that is well adapted for streets in cities where the gas and smoke are injurious to foliage.

THokx (Cratagus). Double White (Oxyacantha Plena). Ias small, double whiteflowers; a highly ornamental variety.

Double Searlet (Coccinea $f$ f . A fine variety; flowers deep crimson with scarlet sliade; very double and considered larger than the double red; fine, rich foliage.

Paul's Yew Double. This is a new sort and the best; flowers in clusters like verbenas; arevery double, large and full, and of a deep rich crimson.

TULIP TREE. Iiriolendron Tnlipifera. A native tree of the Magnolia order; remarkable for its symmetry, its rich glossy foliage, regularly distributed branches and large, tulip-!ike flowers; difficult to transplant unless of small size.

WILLOW. Rosemary Leared (Salix rosmarinifolia). Leaves long, silvery white; branclies stiff, covered with a whitislo down; the gcneral appearance is vcry effectivc and pretty.

Laurel Leaved (Lan rifolia). Beautiful, large glossy foliage; very ornameutal.

Royal Willow. An elegant tree with rich silvery foliage; very effective in groups.

IELLOW WO0D. Virgilia (Lutea). The most beautiful of all the leguminous or pea-blesson trees; very desirable for a single lawn tree; produces panicles fiftecin inches or more in length, of delicately fragrant, creamy-white flowers; bark smooth and polisled; leaves remarkable for their purity of color.

\section{WEEPING DECIDUOUS TREES.}

ASH (Fraxinus). Kuropean Teeping 'Excelsior Pendula'. The common, well known isort; one of the finest lawn and arbor trees, covering a great space and growing rapidly.

BFFCu. Weeping Pendulu. Originated in Belgium, Remarkably vigorous, picturesque tree, of large size; its mode of growth is extrencly curious; the trunk or stem is generally straight, with the branches tortuous and spreading; quite ungainly in appcarance, divested of their leaves-but when covered with rich, luxuriaut foliagc, of wonderful grace and beauty. 
BIRCH (Belula). Cut Leaved Weeping (Lasciniata Pcndula), An elegant, erect tree, with slender drooping branches and fine cut leaves; a magnificent variety and worthy a place on every lawn.

blegans Pendula. A new sort from Furope; habit nearly as peudulous as that of the Kilmarnock Willow.

Young's Weeping (Pendula Youngii). This variety is of a beatiful, pendulous habit, with long, slender shoots of picturesque and irregular form; the leaves are broad, almost heartshaped and very pretty; as a small weeping or namental tree it has no equal; it is a decided acquisition.

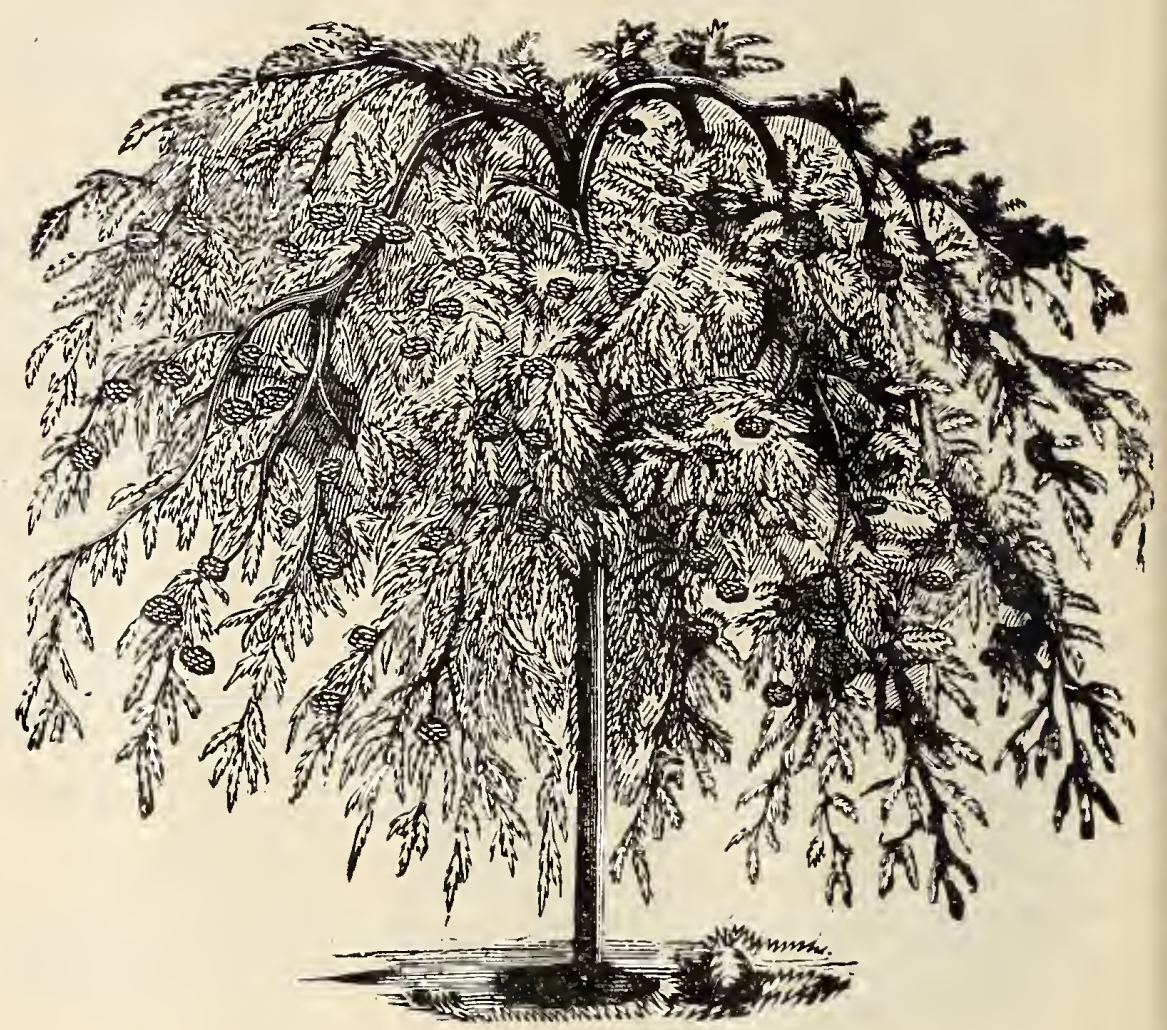

Weeping Mountain Asir. (See page 53).

DOGW001, (Weeping). Cornus rar. Pendula. 'This well known weeper was found wild in Maryland; as with the common one it also has handsome flowers, scarlet fruit and foliage in the fall, together with a pendulous growth, which soon reaches the ground. It differs from almost all other weepers in having an upright central shoot from which pendulous side branches emerge as it grows.

ELM (Ulmus). Pendnla (Camperdow11). Its vigorous, irregular branches which have a uniform weeping habit, overlap so regularly that a compact, roof-like head is formed; the finest Weeping Eim. 


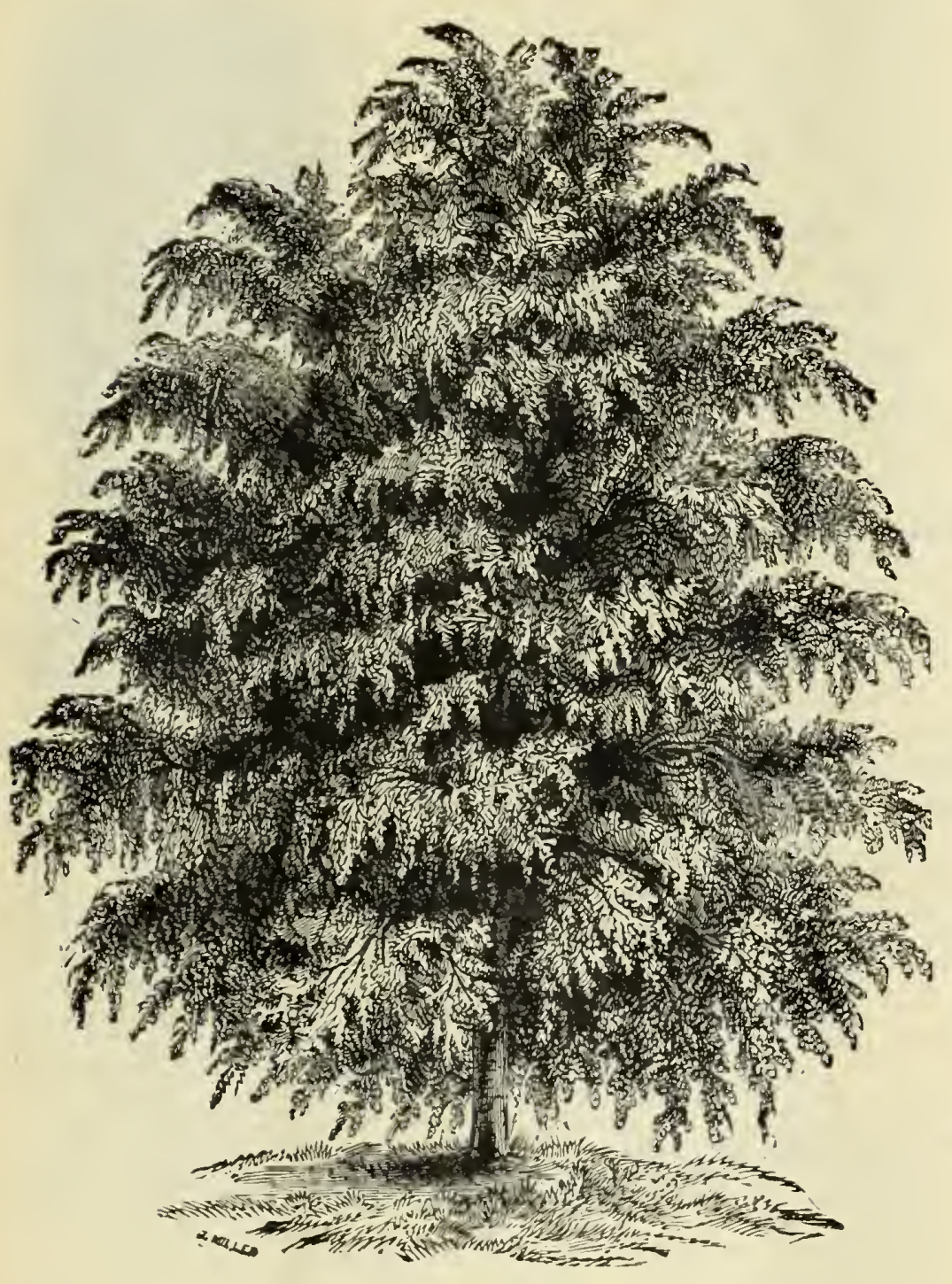

WHTE: LEAVED WEEPING LINDEN.

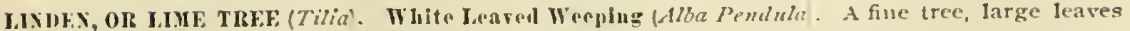
and drooping branclues.

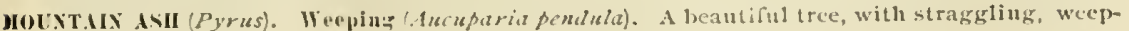
ing branches; makes a fine tree for the lawn, suitable for covering arbors. (Sce page 52 
HULLBERRY. Tea's Weeping Russian (M. Siberica pendula). A gracefu1 and beautiful, hardy tree, forming a perfect umbrella-shaped head with long, slender, willowy branches, drooping to the ground and gracefully swaying in the wind. Foliage small, lobed and of a delightful, fresh, glossy green. The tree is exceeding$1 y$ hardy and of rapid growth and abundant foliage; a d mirably adapted to cemetery planting and susceptible of being trained into a1most any shape.

poplar (Populus). Large Leaved Woeping (Grandidentata). A variety $h$ avi $n g$ when grafted high, long slender branches like cords, which droop very gracefully;

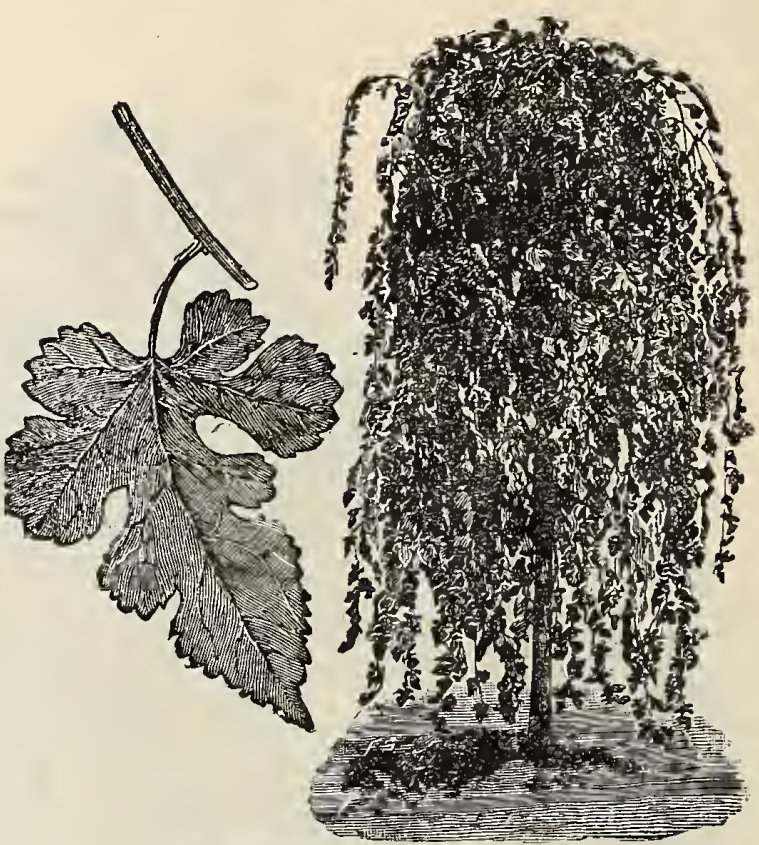

TEA'S WEEPING RUSSIAN MLLBERRY. foliage large, dark shining green and deeply serrated.

WILlow (Salix). Weeping (Babylonica). Our common and well known Weeping Willow.

AMERICAN WEEPLY (Americana pendula). An American dwarf, slender, branched species, grafted five or six feet high, it makes one of the most ornamental of small weeping trees; more ornatnental than the Babylonica.

KILMARAOCK WEEPING (Caprera pendula). An exceedingly graceful tree with large glossy leaves; one of the finest of this class of trees; very hardy.

WISCONSIN WEEPING. Of drooping habit, and said to be perfectly hardy in the northwest.

\section{EVERGREEN TREES.}

ARBOR VITE (Thuja). American or White Cedar (Occidentalis). This is one of the finest medium-sized evergreen trees; one of the best and most available of the evergreens for screens. It is a native of the coldest part of the country, and there are few places whcre it will not thrive. Used more than any other variety for ornamental hedging. By the proper use of the knife and shears it can be made to grow into almost any desirable form.

Chinese Golden (Thuja orientalis). A medium size tree, of great beauty, with erect branches and dense flat foliage.

Compacta (Parson's). Foliage light green; habit dwarfish and quite compact.

Compacta (Pyramidalis orientalis). One of the finest of the Arbor Vita's. Grows upright, compact, and very symmetrical; very hardy, retaining its bea utiful grcen color all the winter.

Douglas (Aurea). New Golden Arbor Vitæ, Goldeu foliage. 
Extcoldes. Heatli-Icaved; of Jow, dwarksh habit, forming a ronud, connpact head, with delicate sliarp-pointed foliagc.

Ciolden (Aurea). A beautiful varicty of the chinesc, conpact and globular in form; color a lively, yellowish grccu.

Globosa. Globc-licaded Arbor Vit:L. Originatel at l'hiladelphia. Forms a dense round shrul); very desirable.

Hovey"s fiolden $(T$. Hoveyt). A natise variety with fine foliage, bright yellow green color; quite hardy, distinct aud beautiful. This is a seedling of the American Atbor Vite, and inherits its hardy constitution.

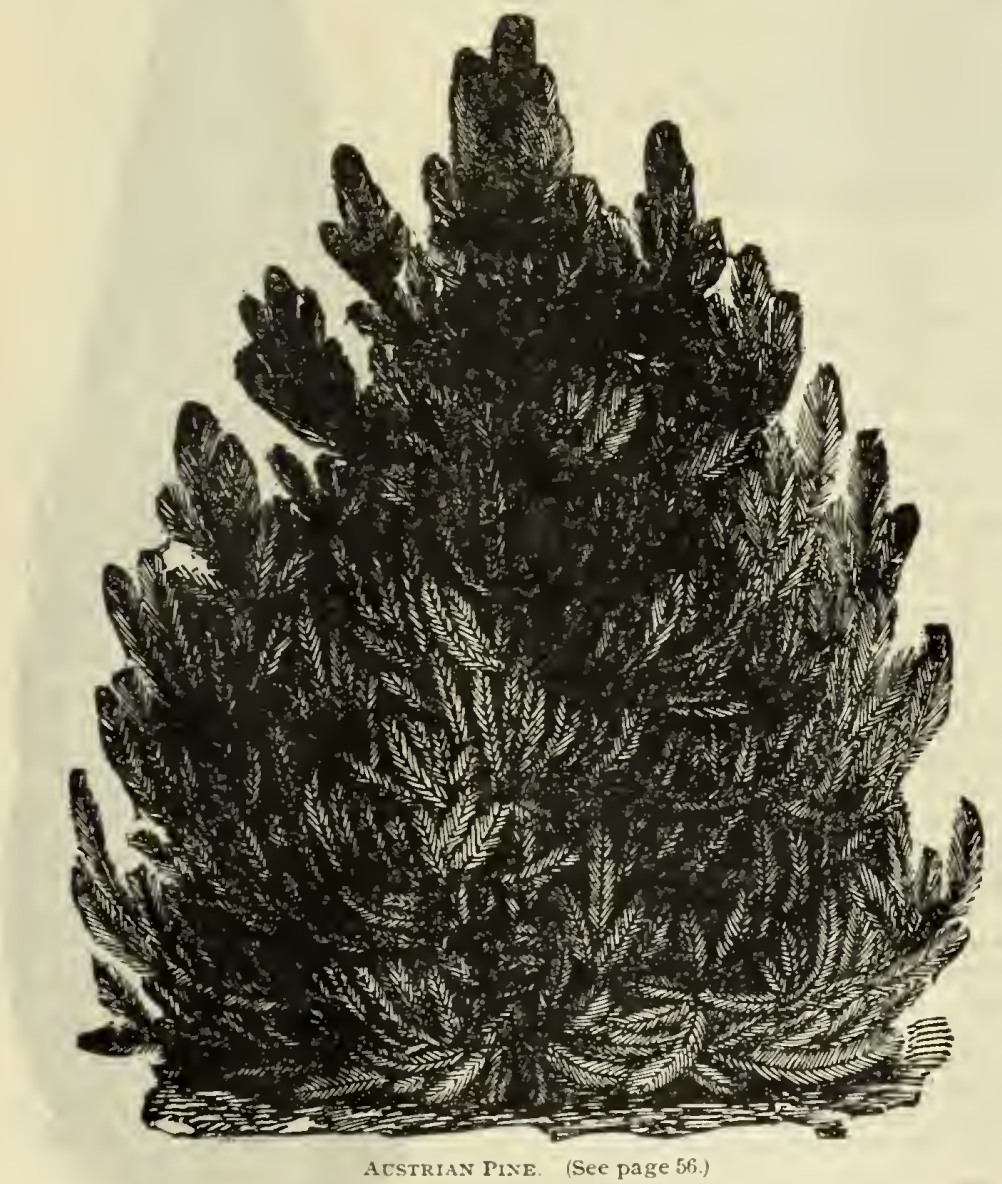

Pyramidals. The most bcautiful of all Arbot vitxs, having dark green compact foliage and remarkally erect form; perfectly hardy.

Pyramidalie Orientalis. A strong upright grower with rather coarse foliage.

Rollinson's Golden (Elegantissima). A new golden va-iety, very bright and distinct. bears the hot weather without fading. Not entirely lardy.

siberian (7: Sibenca). Grows slower and more compactly than the Ancrican, of which it is a varicty; foliage thickct, uore luxuriant, and kecps its color well in winter; perfectly hardy; one of the most desirable and uscful evergreen trces iu this climate.

Tom Thumb، A very dwarf variety; rcsembles T. Ericoides in its foliage. 
FIR (Picea). Balsam or American Silver (Balsamea). A very regular symmetrical tree assuming the conical form even when young, leaves dark green above, silvery beneath.

JUNIPLR (Juniperus). Virginian (Red Cedar). A well knowil tree; its form is usually compact and conical; very hardy and ornamental.

Glacious (Red Cedar). The compact couical habit of this variety, combined with its silvery foliage, renders it very distinct and desirable.

Hiberniea (Irish Juniper). A distinct and beautiful variety of erect, dense, conical outline, resembling a pillar of green; very desirable.

Sueeica (Swedish Juniper). A small-sized handsome pyramidal tree with yellowish green foliage; it is quite hardy.

Savin (Sabina). A low spreading tree with handsome dark green foliage; very hardy and suitable for rock work.

PINE (Pinus). Austrian or Black (Austriaca). A rative of the mountains of Syria; a rapid growing species with long stiff dark green leaves; very hardy. (See illustration page 55).

Seoteh (P. Sylvestris). A native of the British Islands; very rapid in its growth. "A dark, tall evergreen," with bluish foliage aud rugged shoots; hardy, and grows well even on the poorest soils.

White (Strobus.) The most ornamental of ali our native pines; foliage lignt, delicate or silvery green; flourishes in the poorest soils.

Excelsa (I,ofty Bhotan Pine). A native of the mountains of Northern Iudia; leaves very slender and drooping, resembling those of White Pine, but louger; timber soft, white and compact.

Iugho (Mountain or Dwarf). A very distinct species; leaves short, stiff, a little twisted, and thickly distributed over the branches; does not grow large but spreads over the ground, generally assuming a globular form; very dense.

Massoniana. Resembling the Ponderosa, has proved very hardy and is beautiful.

Rigaensis. A species of the Scotch Pine, but more symmetriçal and compact; vigorous and hardy.

Pouderosa. (Heavy Wooded.) This is also a noble tree, attaining the height of 100 feet; found abundantly on the northwest coast of Anerica and California.

RETINOSPORA (Japanese Cypress). This genus com. prises many sorts of wonderful beauty.

Siquarrosa. A small-sized tree with graceful drooping branches and glaucous green foliage.

Auren. Similar in character to the above, with foliage distinctly marked with golden yellow.

Plumosa. A variety with fine short branches and small leaves. The soft, plume-like appearance of the foliage gives it its name.

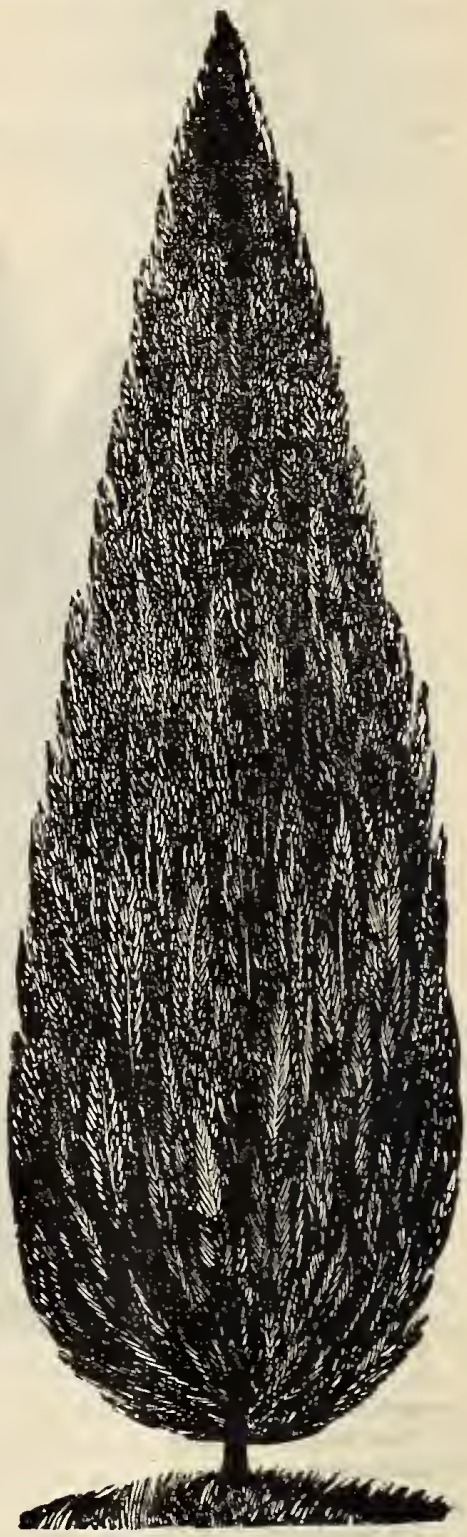

IRISH JUNIPER.

LAWSox's CrPREsS. A 1nost desirable tree from California, with elegant drooping branches and feathery foliage of a dark glossy green line. Not hardy here. 
SPRT(E) (Abes'. Sorwny lixcelsa. A lofty, elegant trec, of perfect pyramiclal labit, remarkably elegant and rich, and as it gets age, has fine, graceful pendulous branclues; it is exceedingly picturesque and beautiful; very popular, and deservedly so, and should be largely planted; one of the best evergrecns for hedges.

Americau Wlite Abba). is tall trec, with compact branclies and light green foliage.

Nigra-Ibluck fipruep. A fine native tree, of compact growth, with smooth blackish bark and hluish lenves: very hardy and beantiful.

Douglas fipuon. I'rou Colorado. large, conieal form, branchcs spreading; horizontal, leaves light green above, glaueous lelow.

Colorado Blue spruee Picea pungens.) This speeien has beculested at various points on the prairies of the West and Northwest with perfect suecess, enduring a temperature of thirty degrees below zero, in exposed

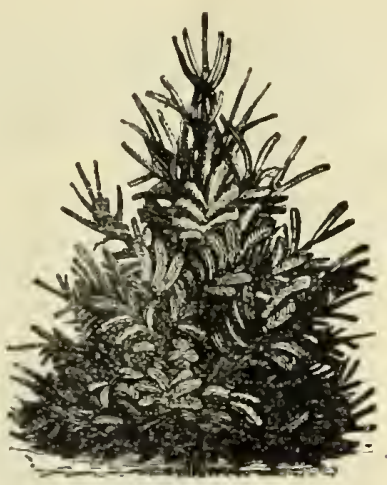

NORWAY SPRCEE. situations, entirely uninjured. This is not only one of the hardiest, but the most beautiful in color and outline; foliage of a rich blue or sage color; it is a valuable acquisition.

ПEMLO(K OR ILEPIX (Canadensis). A renarkably gracefui and beautiful native tree, with drooping branelics and delieate, dark foliage, like that of the lew; distinct from all other trees; it is a beautiful lawn tree and makes a lighly ornamental hedge.

YEW (Fnglisli. (Taxus baccala). The V'cusane renarkable principally for their glossy, dark green foliage; requires a shady and sheltered heation; can hardly be grown in the West.

\section{ORNAMENTAL SHRUBS.}

A7AIIA. Mollis. A heautiful species recently brought from Japan; it las fine large trusses of flowers in shades of pink and yellow; requires sone protection.

Xudiflorn (Swamp Honeysuckte). A beantiful native species, benring landsone, showy, pink flowers early in the spring.

ALTIFA OR ROSE OF SHIROS. llibiseus. These are fine shrubs aucl especially valuable because of their flowering in the fall, whon nearly all wher slisubs ate out of blooni cntirely hardy and easy of cultivation.

Double Lilac (Paronifora'. Very landsome and donble lilac flswering.

Double Purple (Purpurea. Double, reddisln purple; fine.

Double Red (Ruba Plena). Double red flowers.

Totus Albus. Double white, witl pink eenter.

Variegated Ieaved Double Purple. A very showy kind, distinct, leaves variegated with light yellow, flowers double purple; exceptionally fine.

AIMo.P. Amygdalus. Dwarf Double Rose-floweriug. A beautiful slirub, with small, double, rosy blossoms elosely set upon the twigs before the leares appenr.

Dwarf Double White Flowering Pumila $A b a^{\prime}$.

AXEvoN JAP0.1CA (Aba). A very desirable, thorouglily hardy, purc white law or garden plant; grows about 18 inehes high; flowers two inclues in diancter; bloons in the fall; very beatiful for cemetery plots.

Btchtions, Rhamnus. P’urtiug Catharticus'. A valuahle, hardy, robust slirul, with dark, rich fuliage and white fowers, followed by black berrics; used extensively forlyedges, and locing very hardy, is one of the most desirable plants for this purpose.

bERIERRT. Commou, V'ulgaris'. A niceslirub, with yellow fowers in droopung racenes in May June, and followed with orange scarlet fruit. 
BERBLRIX (Berberis). Purple Leaved (Purpurea). An interesting and beautiful variety with violet purple leaves and fruit.

Cilicaxthus. Sweet Scented Shrub) or Allspice (Floridus). Sweet scented shrub. An interesting shrub, having a rare and peculiar fragrance of wood and flowers its blooms are abundant and of a peculiar chocolate color.

CCRRANT (Rzbes). Crimson Flowering (Sanguineum). Small deep flowers blooming abundantly and early in spring.

Double Crimson Flowering (Flove Plena). A variety of the Crimson with double flowers in.Iuly. a most beautiful flowering shrub.

Gordonianum (Gordon's Currant). A hardy and profuse blooming shrub; flowers crimson and yellow in pendent bunches in May.

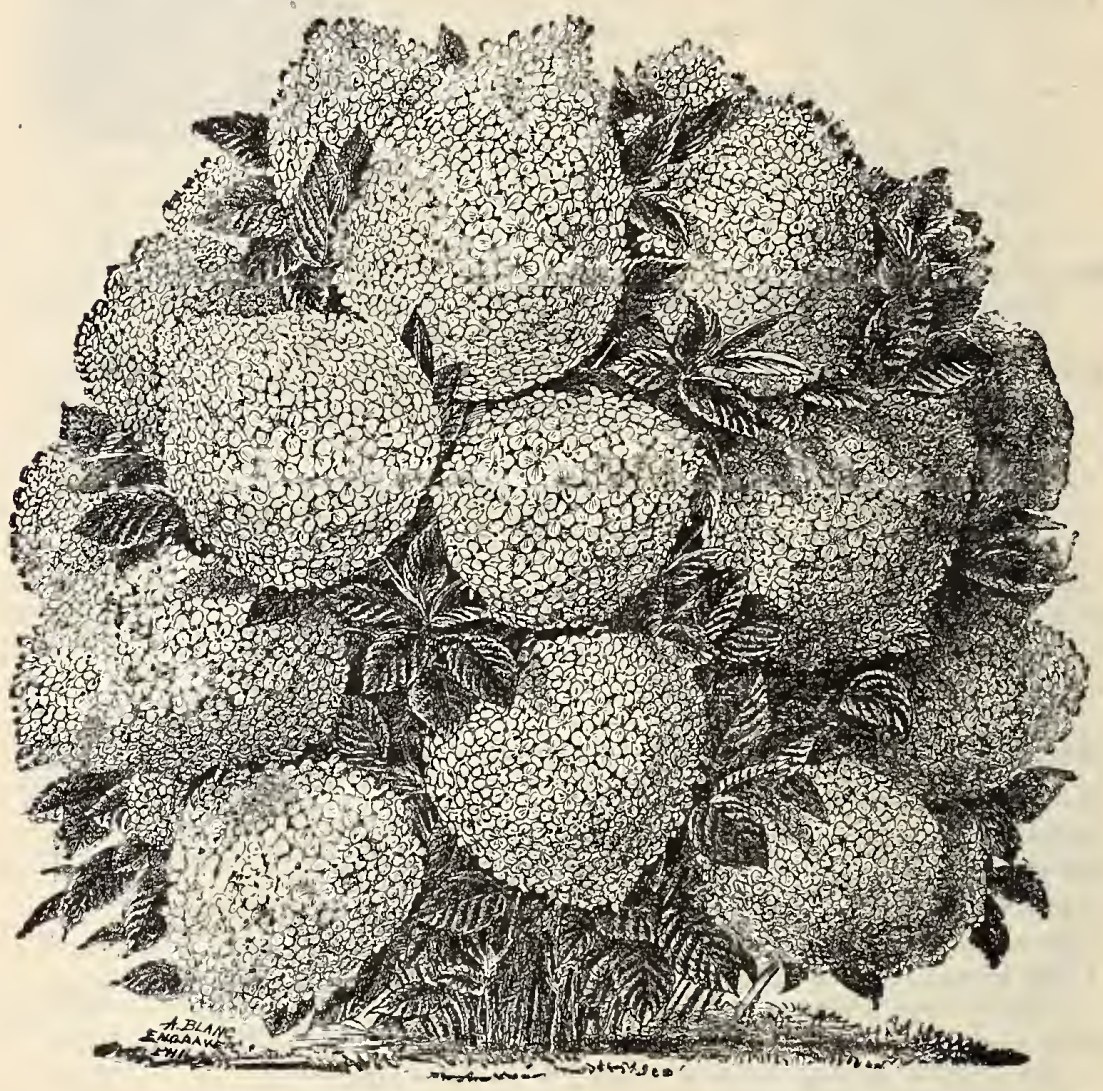

Hydrangea-Paniculata Grandrilora. (See page 59).

IDIPHE (Mecereum Pink). Flowers appear very early, beforc the leaves, and are very beautiful.

DECTZIA Slender Branehed (Gracilis). A charming species, introduced from Japan by Dr. Siebold; flowers pure white; fine for pot culture, as it flowers freely at a low temperature in the winter.

Crenata Flora Plen?. Flowers double; white, tinged with rose; one of the inost desirable flowering shrubs in cultuvation.

Candidissima. Doublc whitc flowering; one of the finest shrubs, producing snow-white flowers of great beauty, and valuable for bouquets and baskets. 
Pride of liochester. A new variety raised from Deutzia crenafu fora plena, and producing large, double, white llowers, the back of the petals being slightly tinged with rose; it excels all of the older sorts in size of flower, leugth of pauicle, profuseness of bloom and vigorous liabit; regarded as a charming açuisition.

DOGW00D. Cormus (Mascula Variegata). Leaves striped with pale yellow or white; very beautiful.

('ornelinu Cherry (Mascula). Bright yellow flowers in May.

Red Brauched (Sanguinea). Very' conspicuons and ornamental in winter on account of its blood-red bark.

E.oxylCs. Inruing Bush strawberry Tree). A very oruamental and showy shrub, the chief beaty consists in its brilliant dark red berries, which hang in clusters from the branches until mid-winter; planted with a background of evcrgreens, the effect of contrast is very fine; leaves scarlet in a utumn.

Europaus (European Euonymus). Forms a tree sometimes 30 feet in heighth; fruit rose colored.

EL.EAGXS. Argentea. (Silver-Leaved Oleastcr). A wative spccies of erect grow th and beautiful silvery foliage; flowers small, yellow; July and August.

ELDER (Samb́ucus). Anrea. A handsome variety with golden yellow foliage and clusters of pure white flowers; very desirable for ornamenting lawns.

Cut.Leared (Lasciniala). A fine variety of vigorous growth and deeply lasciniated foliage.

Viniegated-Leared (Variegala). A hardy, variegated shrub; very showy and fine.

FILBEIT. I'urple Iecared (Corylus). A vigorous shrub with large, deef purple leaves; very ornamental; produces good fruit.

Fonsitill. Viridissima. Golden Bell). Leaves dark green; flowers bright yellow, very early in spriug; a fine, hardy slirub; introduced by Mr. Fortune from China.

IIALESI.1. (Silver Bell). Produces in the spring very pretty white, bell-shaped and drooping flowers, somewhat resembling those of the Fuchsia.

IIOXfIStckLE. Upright Lonicera). Red Tartarian. A well known shrub; flowers bright pink, which appear in May.

White Tartariau. Like the preceding, but has dull, white flowers.

IIYURANGEA (paniculala grandiflora) A fine shrub of recent introduction, blooming from July to November, large, showy panicles of white flowers in the greatest profusion; it is quite hardy, and altogether a most admirable shrub for planting singly on the lawu or in the margin of masses; to produce largest flowers it should be pruned severely in the spring and the ground enriched see page 5s.

Otaksa (Japonica var. Olaksa). This is another new variety; foliage a beautiful dark green; fowers rose colored, borne in immense panicles and in great profusion; requires some protection in winter.

JASMIXI I (Jessamine). Sudillorum. A shrub with long slender brancles and small deep green leaves; has a profusion of richly scented yellow flowers through spring and summer.

KLRRIA (Corchorus). Japonica. A slender grecn branclued slirub five to six feet high, with globular yellow flowcrs from Ju1y to October.

LILAC (Syringa), Persica Persian Lilac'. Native of Persia; from four to six feet high, with smali foliage and bright purple flowers.

Counon Purple (Vulgaris Purpurea). Bluish purple flowers.

bouble Lilar (Lemoinei Flore Pleno). A new and choice variety of the Lilac, producing long racemes of double purple flowers, lasting longer than the single sort. A valuable acquisition.

Iarte Flowering White Alba Grandiflora). A beattiful variety; has very large, pure white panicles of flowers; considered the best.

WhIte Persian (Persica Alba). A fine sort; white flowers delicatcly tinged with rose color.

PLty (Prunus). FIowering (Trilobala). Flowers semi-double, of a delicate pink, closely set aloug the slender branches, and appearing early in spring. A very desirable adclition to early shrubs, and becoming very popular.

I CRPL. FRING: 'Smoke Tree'. (Rhus Continus. A very unch admired and conspicuous shrub or small tree, with spreading habit, so as to require considerable spacc; covered in midsummer with a profusion of dusky fringe-like flowers; desirable for its striking pcculiarity of flowering 
PRIVET (Common). (Ligistrum vulgare). Has delicate foliage, pretty wlite flowers, and bunches of black berries; in, warmer climates it is an evergreen; the leaves hang on very late. A valuable ledge plant.

California (Ovalifolium). A desirable shrub, ncarly evergreen, that produces delicate white flowers in great profusion; the flowers possess a pleasant heliotrope fragrance.

QUiNCE (Japan). (Cydonia Japonica). Scarlet. An old and esteemed variety, having a profusion of bright scarlet flowers in early spring, and one of the best early shrubs; makes a beautiful and useful hedge.

Blush Japan $(A l b a)$. A beautifu1 variety of the preceding with delicate white and blush flowers.

Grandiflora. Flowers nearly white, very showy; fruit extremely large, almost pear-shaped.

SNOWBERRY (Symphoricarpus). A very pretty shrub, with clusters of rose colored flowers early in spring, followed by waxy white berries, which haug on through part of the winter.

SPIREA (Meadow Sweet). The Spiræas are all elegant low shrubs of the easiest culture, and their tlooming extends over a period of five months.

Ariafolia (White-beam Tree-leaved Spiræa). An elegant species from northwest America; habit dense and bushy, plant entirely covered with greenish white blossoms in June.

Billardi (Billard's Spiræa). Rose colored, blooms nearly all summer.

Crenata (Hawthorn-leaved Spiræa). Dwarf habit; flowers dull white. Free bloomer in May.

Callosa (Fortune's Spiræa). Has large panicles of deep rosy blossoms; grows freely and blossoms nearly all summer. Fine.

Collosa Alba (Fortune's Dwarf White spiræa). A white flowering variety of dwarf habit; very fine; keeps in flower all summer.

Obovata (Obovate-leaved Spiræa). Small and glossy toothed leaves and small spikes of white flowers. July and Aug.

Plum-Leaved (Prunifolia). A very beatiful variety; flowers white and very double, like English daisies; very profuse, blooms in Apri1; foliage turns a beautiful bronze color in autumn.

Reevesii or Lanceolata (Lanceleaved Spiræa). A charming shrub with narrow pointed leaves and large round clusters of white flowers that cover the whole plant; blooms in May.

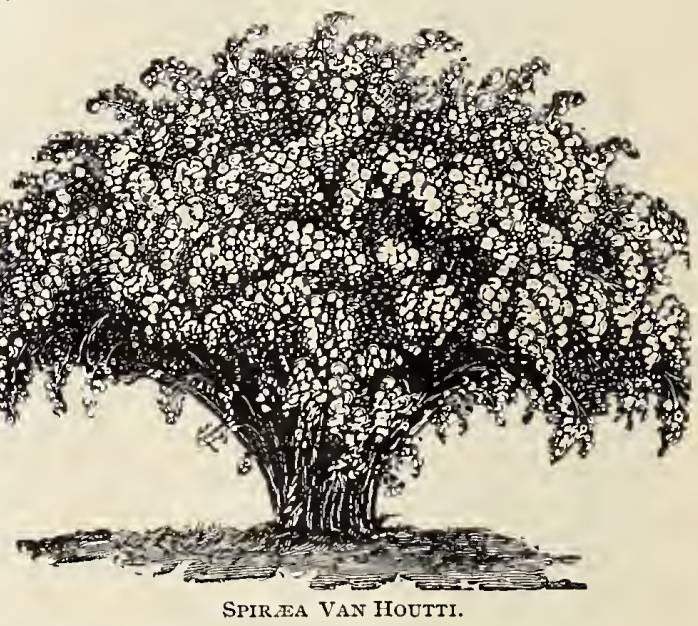

Flore Plono (Lance-leaved Double Spiræa). A beautiful double flowering variety.

Thunbergii (Thunberg's Spiræa). A very pretty white flowering variety with narrow linear leaves; valuable for forcing; one of the first to flower.

Van Houtti. One of the most charming and beautiful of the Spircas, having pure white flowers in clusters or panicles an inch in diameter. Astonishingly profuse in bloon, and plants remarkably vigorous and hardy. But recently introduced from France, and there is no more desirable flowering shrub in cultivation.

Golden-Ieared (Opulifolza Aurea). An interesting variety with golden yellow tinted foliage and double white flowers in June; very conspicuous.

SYRIXG (Philadelphus). All the species and varieties of the Syringa have white flowers, many of them quite fragrant.

Large Flowered (Grandiflorus). A conspicuous, showy kind, with large flowers and irregular branches.

Coronarius (Garland Syringa). A well known shrub, with pure white, sweet scented flowers; one of the first to flower.

Flore Pleno (Double-Flowering Syringa). A variety with partially double, very fragrant flowers; does not bloom much. 
Folils 1 ureis Golden-Leaved Sy-ringa). A very pretty dwarf plant, with golden yellow foliage. It keeps its color the entire season, and will be found valuable for creating pleasing and striking contrasts with purple leaved shrubs.

TAMARIX. Afrlen (Africana). This is a very beatiful shrub, with small leaves, somewhat like the Juniper, and delicate, small pink flowers in spikes in May.

VibCRICy. Snow Ball (Steritis). A well known favorite shrub, of large size, with globular clusters of white flowers in June.

Plicatum (Plicale Tiburnu'. A rare and exceedingly beautiful specics from Japan. Flowers pure white, in very large globular heads.

WIEGELA. Desbolsl. A beatiful variety, with deep rose-colored flowers, rcsembling rosea, but flowers nuch darker; one of the darkest and best.

lortensis Nivea. Flowers pure white, retaining their purity during the whole time of flowering; foliage large; habit vigorous; a very profuse bloomer.

Van Houtti. A new variety of vigorous growtl, with dark, rich crimson flowcrs, produced in great abundance; darker than Desboisi, and a decided acquisition.

Variegated Leaved (Fol. Variegata. I,eaves bordercd witl yellowish white, finely marked; flowers bright pink.

Candida. The hest white variety. A large sized shrub of crect, vigorous growth, producing a great profusion of pure white flowers in June and July; especially valuable, being clear white and a much better grower than Hortensis Nives; a valuable feature of the rariety is its continuing to bloom moderately throughout the summer.

WIITE FRIYGE (Chionanthus). Virginian (Firginica). One of the best large shrubs or small trees with superb foliage, and delicate, fringe-like white flowers.

\section{EVERGREEN SHRUBS.}

The best of success has not attended the cultivation and growing of the Evergrcen Shrubs on the southwestern prairies. They require a cool, shady location, aud by proper attention can be made to succeed moderately well.

ASHBERRY. Mahonia (Holly Leaved) (Aquifolia). A most beautiful shrub, with glossy, holly-like leaves, which change to brownish green in wiuter, with clusters of bright yellow flowers in May; makes a good hedge.

HoX $B u x u s)$. Dwarf (Sufruticosa). T"sed principally for borders and cdging, for which purpose it is the best plant in cultivation.

Sempervirens Tree Box (Arborescens). A rery desirablc small tree in the yard or garden, well adapted to small places; prefers a shady situation; it cau he made to assume any form.

HOLLY (llex). Green-Leaved, Deep green, glossy shining leaves, with bright red bcrries through the winter; langely used in Christmas decorations.

Rhodoleudron. These are the most magnificent of all livergreen Shrubs, with rich, green foliagc and supcrb clusters of showy flowers; they flourish locst in a peaty soil, and like Azalias, are the most effective when grouped. I'lant in sheltered locations. Soil strongly impregnated with lime should be rcmored before planting and the space filled in with leaf mould and peat or muck mixcd, or other good soil tolerably frec from linc. The Catawbiense varieties have lilac-colored and red flowers, and are perhaps the most liardy sorts. 


\section{HEDGES.}

The idea of planting hedges for use and ornament, and screens for the protection of orchards, farms and gardens, is a practical one, and rapidly becoming appreciated.

They serve not only as protection against the ferce winds, but there is much less trouble from the blowing off of the fruit. Some writers tell us that the tcmperature is warmer in the vicinity of evergrcens. However this may be, we know that our gardens are earlier and our fruits tipen better when protected by such screens. Nothing can be more bcautiful than ornamental Hedges of Evergreens, or shrubs, well kept and pruned to serve as boundary lines between ncighbors, or as divisions between the lawn and garden, or to hide unsightly places. By using medium sized plants a hedge can be made as cheeply as a good board fence can be built, and then with a little care, it is becoming every year more and more "a thing of beauty." We all know that such hedges continue a principal attraction in our bcst kept places.

To secure a good hedge it is necessary to plant well. Dig a deep, wide trench, and work the soil thoroughly about the roots. Press the ground firmly, and mulch heavily for a distance of two or more feet on either side, according to the size of the plants. This is especially necessary with evergreens, and all exposure of the roots to the sun and air must be strictly avoided.

Evergreens should be pruned in the spring just before they commence growing. Summer pruning or sheariug may be practiced on the Arbor Vitæs, Cedars, etc.

\section{EVERGREENS FOR HEDGES AND SCREENS.}

A rhor Tita (American). This plant is one of the finest of all Evergreens for screens. It is very hardy and easily transplanted. It grows rapidly and with little care, or rather by easy managemeut. It soon forms a most beautiful hedge, dense and perfectly impervious to the sight. Even in three or four years very handsome and close hedges can be produced.

Siberian. This variety is admirably adapted for hedges. It is richer in color and more compact in growth than the American; very hardy.

Hovey's. This is a very bright color; almost golden; very hardy and beautiful.

Ton Thunb (Dwarf). Makes exceedingly pretty borders where it succeeds.

Box (Dwarf). This plant is used extensively to form edgings for borders where it succeeds.

Henlock. Extremely fine and rich colored when once started.

Norway Spruce. Forms a beautiful and desirable screen or shelter, where a rapid and high growth is required, as for sheltering from cold winds, planting on the borders of grounds and plantations of fruit trees, etc. With careful pruning it can be kept low and in good shape and thus makes a highly ornamental hedge.

For shelters and screens in orchards and other places, we recommend the Norway spruce, Scotch, Austrian and white Pines.

\section{DECIDUOUS HEDGE.}

Honey Locnst. Very hardy and desirable for the North.

Osage Orange. Highly esteemed at the West and South; not hardy enough for the Northeru States.

Japan quince. Unquestionably a fiue plant for an ornamental hedge. Grows very compactly, will submit to any amount of pruning, while the brilliant and showy scarlet flowers make it exceedingly attractive.

Privet. Plant four inches apart and keep cut back well after the first year; when trained well is one of the most ornamental hedges for lawns and cemeteries.

The following are also very desirable for ornamental hedging, descriptions of which will be found under the proper headings in this catalogue.

Purple Berberry, Roses, Altheas, Spiraas, Tartarinn Ironeysuckle.

\section{HARDY CLIMBING AND TRAILING SHRUBS.}

AHPELOPSIS (Veitchii). Japan Creeper (Boston Ivy). Foliage smaller than those of the American and more dense, forming a sheet of green. The plant is a little tender while young and should be protected the first winter. When ouce established it grows rapidly and clings to a wall or fcuce with the teuacity of ivy. The foliage while handsome in summer changes to a crimson scarlet in autumn and is very beantiful for covering walls, stumps of trees, rockeries, etc., and for ornamentation of brick and stone structures it has no equal. 
Guivon:olia (Virginia Crecper). A native vilue of rapid growtl, with large, luxuriant foliage, Wicin in the autumu assumes the most gorgcous and magnificcnt coloring. 'The blossoms, rinich are inconspicuous, are succeeded by handsome dark bluc berries. The vine is best calculated to take the place in this country of the celebrated Finglisli Ivy, and is really in suminer not inferior to it.

ARISTOLOCuII Birthwort. Sipho Duchman's Pipe). A twining vine of rapid growth, having large, dark green leaves, and curious brownish, pipe-shaped bloom.

IKEII. Quinuta. A very bcautiful, perfcetly hardy, fast growing Japan vine, with magnificent foliage; producing flowers in large clusters of chocolate purple color, possessing a most delicious perfume; unsurpassed for covering trellises and veraudas, the foliage never being attacked by insects.

BIGONA, OR TRUMLET FLOWER. Scarlet Radicans). A splendid climber, vigorous and hardy, with clusters of large trumpet-shaped, scarlct flowcrs in August.

Large Flowering (Grandiflora). A magnificent vine with large flowers, but not so hardy.

IBTTERSWEET. Stuff Tree (Celastrus scandens). A well known native climber of extraordinary and powerful growth; foliage bright and shining; its orange-colored seed vessels, displaying their crimson sccds, are quite ornamental in winter; one of the finest and most 1 uxuriant climbers; should be largely planted.

CLEMITIS, OR VIREIN'S IBOWER. The different varieties and species of clematis now in curtivation are of the lighest beauty and utility. They vary greatly in their foliage and flowers, and are adapted to various uses; somc of then, such as our common native sort, (C. Virginiana, and the European Virgin's Bower, (C. flammla), are quite fragrant, and are particularly attractive on this account. The large-flowered varieties, like the well known $C$. Jackmanni), are extremely showy. These plants when traincd on trellises, and over porches, pillars and rockwork, produce great masses of bloom, which make a grand appearance, especially when contrasting colors are in proxinity. Good rich, deep, sandy loam, mulched in wintcr with wcll rottcd manure, where it has partial sluade and a liberal supply of water at the roots will producc the best results both in vigor of plant and richest slieets of bloom.

Ameriean (Vivginiana). One of the most rapid-growing kinds, covercd in August with the greatest profusion of pale white, fragrant flowers, which are succedcd by brown, hairylike plumes; very beautiful and unique.

Cocciuca. Distinct from other varieties; bright coral scarlet flowers; July to October.

European sweet (C. flammula). T"te flowcrs of this variety are very fragrant; requires a slight protection in winter; very dcsirable.

Viticclla. An old Firopean sort, with small blue fowers on long stcus; very lardy and vigorous.

Vitalba. An old Einropean variety, with small, fragrant, greenish-white fowers; of rapid growth.

CIAnTIS, JARGE FLWERIAG. Alexandria. This is one of the continuous blooning sorts of real merit; has a vigorous habit of growth, and in flower is rcmarkably showy and ornamenta1. The flowers are large and of a pale reddislı violet color; July to October.

Ducluess of Elinhurgh. This is without doubt the best of the pure whites; deliciously scented.

Fairy Queen. Pale flesh color with light piuk bar; very attractive.

Fair liosamond. Blusll white, with reddish bar; fowcrs fragrant.

llenryi. Fine, large, pure white; one of the best long bloomers

Jackman's (Jackmanni. A very profuse bloomiug variety; with flowers from four to six inchea in diameter, of an intense violet, purple color, borme successionally in coutinuous masses out the suminer shoots.

Jackmanni (Aba). A fine variety of the preceding, witl pure white flowers.

Priuce of Wales. Deep purple flower rescmbling Jackmanni.

Star of India. A very showy, very free flowering sort, with large flowers, first of a reddish plum color, changing to a violet purple, with turky red bars in the centcr of each flower leaf; a distinct varicty of great meriot; July to October.

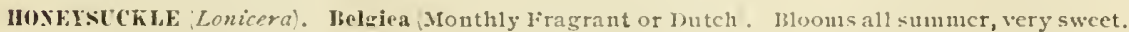
red and ycllow flowers.

Common Wonlliue Periclymena. A strong rapid grower, lowers very show, red outside buff within; June and July.

Chinese Tuining Japonim. Holds its foliage nearly all winter, blorns in July and september and is very sweet. 
Canadensis (Canadian Honeysuckle). A very robust, rapid grower, with large gla ucous leaves and yellow flowers.

Halliana (Hall's New). Nearly evergreen; flowers pure white changing to yellow, producing abundantly; fragrant like a Jassemine; the best bloomer of all.

Yellow Trumpet (Aurea). A well known variety with yellow trumpet flowers.

Scarlet Trumpet (Sempervirens). This and its varieties are the handsomest in cultivation; it is a strong, rapid grower, and produces scarlet inodorous flowers all summcr.

IVY. The Evergreen Ivies often suffer in winter, if exposed to the sun, and should therefore be planted on the north side of a wall or building.

Iledera (English). A well known old and popular sort.

New Silver-Striped. Deep green leaves, heavily margined with white; very striking.

Variegated-Leared (Fol. Variegata). With smaller leaves than the preccding.

SLLK VINE. Periploca (Graca). A graceful rapid growing vine with dark glossy foliage and relvety brown flowers; will twine thirty or forty feet high.

WISTARIA. Chinese (Sinensis). A most beantiful climber of rapid growth, and proulucing long pendulous clusters of pale blue flowers, when well establishcd makes an enormous growth, is very hardy, and is oue of the nost superb vines ever introduced.

Doublo Purple (Flore Pleno). A rare and charming variety, witl perfect double flowers, dceper in color than the single, and the racemes of remarkable length. The plant is perfectly hardy, resembling the wistaria Sinensis, so well known as one of our best climbing plants.

Chinese White. Introduced by Mr. Fortune from China, and regarded as one of lis greatest acquisitions.

American White. A native seedling, pure white; bunches short; a free bloomer.

\section{LISTS OF TREES AND SHRUBS FOR SPECIAL PURPOSES.}

For the benefit of patrons who have not had opportunity of observing the general growth and appearance of various kinds of trees, evergreens, and shrubs, we give the following lists, by which they will be better enabled to make selections, descriptions of which can be seen in their proper places in this catalogue.

\section{TREES ADAPTED TO STREETS, AVEXUES, PARKS, AND LIRGE GROUYDS.}

\section{White Elum}

Flowering Horse Chestuut

American Linden

European Linden

Norway Maple

\author{
Sugar or Hard Maple \\ Silver or Soft Maple \\ Catalpa \\ Lombardy Poplar \\ 'ulip Tree
}

Carolina Popla

White Ash

Excelsior As1

Box Elder

TREES, ETERGREES, AND SIRUBS, FOR PARKS, EXTESAYE GROUNLS, LAWX, EITY LOTS, ETC.

\author{
Cut-Leaved Alder \\ Cut-Leaved weeping Birch \\ Catalpa \\ Dogwood \\ Horse Cliestnut \\ Judas Tree \\ Kaulreutcria
}

\author{
Laburnum \\ Liquidambar \\ Lindens, all the varieties \\ Magnolia \\ Maples, Weir's Cut-Leaved, \\ Purple-Leaved and Norway \\ Mountain Ash, all varieties
}

\author{
Mulbcrty, all varieties \\ Plum, Prunus Pissardii \\ Salisburia \\ Tulip Tree \\ Wceping Elm \\ Kilnar wock Weeping Willon \\ Wisconsin Weeping Willow
}

\section{EVELGREEXS.}

Arbor vitas-American, Compacta, Golden, Globosa, Hovey's Golden, Pyramidalis, siberian. Rollinson's Golden.

Balsaln Fir

Junipers-Irisl, Swedish, Sarin

Red Cedar

Pines-Austrian, Scotch, White, Excelsia, Dwarf, Rigaensis

Retinospora, the varieties described Spruce-Excelsior, Colorado, Black

Hemlock

\section{SIIRTEs.}

Altheas, all the varieties Alinonds-Dw'f-White, Pink Berberries-Purplc, Connun Calycantlus

Dentzias, assorted

Forsythia
Filbert-Purple-Leaved Halesia

IIoneysuckle

IIydrangea-Pan.Grandifora

Lilac, varietics

Friuge-Furple, White
Quince-Japau

Snowberry

Spirca, all varicties

Snowball

Syringas, all varieties

wiegclas, assorted 


\section{ROSES.}

\section{HYBRID PERPETUAL (HYBRID REMONTANT) ROSES.}

This group comprises, for the most part, the roses for the multitude They are mostly hardy. rigorous, easy of culture.

As a general rule, they thrive best in well prepared loam. Close pruning is generally re. quired, but slould be rcgulatcd to some extcut by the ratc of growth of each variety, those of vigorous habit uot requiring to be cut back so unuch as thosc of slower growth. The flouers range in color from the purcst white to the decpest crimson, with the intermediatc shades of pink, blush, cherry, carmine and peach. The term perpetual might lead some to think that they are as con. stant bloomers as the evcrblooming roscs. This is not the casc. They flower freely in June and at short intervals during the sumucr and fall.

Remedy for Mildew. The mildew is perhaps the most injurions disease. It is generally caused by extremcs of heat and cold, and by a long continuance of damp, clondy weather. The best remedies are sulphnr and soot; one of these should be applicd the moment the disease makes its appcarance. It is a good plan to sprinkle the plants with watcr, so that the substance applied will adhere.

Achille Cionod. Dark crimson red; very large, full and bold flower; one of the best blooners.

Abel Carriere. Purplish crinson, wilh frety celter.

Alfred Colomb. Bright carmine red, clear color, targe, deeply built form: excedingly fine: very fragrant; one of the very best.

American lienuty. An liverblooning liybric Perpetual. 'le flowers are very large, of beautiful form and very double, color a deep rich rose. The fragrance is delightful, resembling I,a France.

Inne de Diesbach. Carmine, beantiful wade; moderately full and very large

Anguste Mle. Clcar rosy pink; very large and finely cupped; vigorous, fine.

Iburoune de llayunrd. P’ure white, medium sized flowers; good form; very double aucl one of the nost persistent of bloomers.

Beauty of Walthau. Almost full; beantiful bright clicrry color.

Baroune Provost. Ineep rose; very large aucl full; a vigorous grower and abundant bloomer: nne of the oldest and finest of this class.

Bell of Sormandy. Silvery rosc color; large, full anel globular in form; extra fine.

Baroness liot hsehild. I,ight piuk, cupped form, very symuctrical, without fragrance; very heau tiful; a good grower.

Coroline de Sausal. Clear, delicate flesh color, becoming bluslı; magnificent variety: the hest rnse of its color in the cataloguc; growth vigorons and foliage luxuriant.

Coqnette des Alps. White, lightly shaded with carnine; of mediun size; a free blooner.

Coquetto des Blanches. Purc whitc, flowering in clusters; a very frec bluouer.

Clinblug Jules Margottin. Carmine-rose, lightened with pink; full fowers of medium size, very pretty in bud. "This is a dccided acquisitiou; the flowers are the same as in the old variety" except that they are a little smaller, and quite as freely produced; the growth is more vignrous.

Cllmblng Virtor Verdier. Rosy carmine, purplish edges; slowy and very effective.

Dlnsmore. A true perpetual, lowering very freely the whole season; flowers large and very double; color deep crinsou. The plant is of a dwarf, bushy habit, every shoot produciug a bucl.

General Washington. Brilliant rosy criuson; large aud double; fine.

fieneral Jacfueminot. Brilliant crimson scarlet; very showy and effective.

filant of Battles. Very brilliant crimson ccuter; dwatf halit, free bloomer, and one of the very best.

(ilory Lyonaise. Originated at Lyons, France, and clainterl to be a Villow Ilyloricl ferpetual. It is described as being clear chrome yellow, with rich, creatuy white borcler; the flowers are large, very dull and delightfully sweet.

llermosa. An excellent rose; blooms iu tiue clusters; large, very double and fragrant: color bcau tifnl clear rose, a constant bloomer; liatrly; one of the best.

Jules Margottin. L,ight brilliant crinson; large, full and beantiful.

John llopper. Deep rose, with crimson center; one of the best.

louls Van lloutte. Beautiful maroon; medinu sizc, full, of fine shape, delicionsly petfuned.

La leeine. Deep rosy lilac, large and full, sweet aut double.

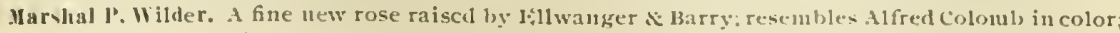
said to be more vigorous and hardy: 
Madame Laffay. Rosy crimson, large and double; oue of the oldest and best.

Marlame Clas. Wood. One of the most beautiful Hybrid Perpetual Roses ever introduced. The flower is extra large, full and double; color dcep rosy crimson, sometimes brilliant scarlet, with maroon shading; it blooms soon after planting out and continues to bloom all summer.

Hadame Vietor Verdier. Bright cherry rose; large, compact and finely cupped: blooms in clusters: a free bloomer.

Marie Banman. Brilliant carmine crimson; large, full and of exquisite color and form; very fragrant.

Panl Jeyron. Deep rose color, good foliage, by far the largest variety in cultivation: free bloomer.

Pius the Nintl. A bright purplish red, changing to violet; very large and full; robust and profuse bloomer; one of the best.

Prince Camille de Rohau. Deep velvety crimson, large, moderately fu11; a splendid rose.

Perle des Blanches. Vigorous, very large and full, well formed; white center, changing to flesh color.

Pierre Notting. Large, very full, globular; dark red or crimson shaded violet; fragrant; vigorous; one of the very best dark roses.

Sir Garnet Wolseley. Vermillion shaded with bright carmine; color well maintained throughout,

Victor Verdier. Clear rose, globular, fine form aud free bloomer; superb.

Star of Waltham. Carmine-crimso11, medium or large size; semi-globular, full; foliage very large. smootl green wood, with occasional red thorns.

Sydouic. Blush, large and fine, distinct; a vigorous grower.

\section{HYBRID TEA ROSES.}

This class is the result of a cross between the varieties of Hybrid Perpetuals and Teas. The great advantage claimcd for them is that they combine the frec flowering qualities of the Tea class with he rich coloring and to some extcnt the hardiness of the Hybrid Perpetual. Though not as Iardy as the Hybrid Perpetual they are much hardier thau the Teas, and will stand out during w. pter wherever the Bourbon will, and whcre the Teas would be killed to the ground.

Capeain Christy. Delicate fiesh color, shadcd rose in the centcr; a large, fiuely formed flower.

La France. Delicate silvery rose, very large and full; an almost constant bloomer, equal in delicacy to a Tea rose; the most pleasing fragrance of all 1oses; a moderate grower; semi-hardy.

Purital. A beautiful pure white variety of the most delicious fragrance. In size and shape of flower it very closely resembles the Hybrid Perpetual class, with the flowering habit of the everblooming section.

Pierre Guillot. Briglit dazzling crimson, passing to brilliant carmine, petals beautifully veined with pure white, flowers large, very double and full; a free bloomer and very sweet.

William F. Bennet. Beautiful glowing crimson, similar to Geu. Jacqueminot; very fragrant; a very free bloomer, bint only a moderate grower.

\section{MOSS ROSES.}

Well-known, extremely hardy. Some of them blossom in the autumil and are so called "Perpetual Moss."

Etua. Bright crimson, very double; superb; fragrant; very $1110 s$ y

('aptain John Ingram. Dark velvety purple, full and fine.

Countess of II nrinais. Whitc, slightly tinged with flesh; the best white moss.

(ilory of Hosses. Pale rose, very large, full ard beautiful.

Lanei. Large, bold flowers, very double, full and fragrant; color rich crimson. delicately shaded with rosy purple; vcry mossy.

Laxembourg. I,arge, cupped, fine purplish crimson; a luxuriant grower and free bloomer.

Perpetual White. Pure white; blooms in large clusters.

Princess Ad"laicle. Blush, becoming quite pale; very double and well formed; the n11ost vigorvus grower of all the Mosses.

Salet. Clear rose color, very double, of vigorous growth and abundant bloom; perpetual.

\section{CLIMBING ROSES.}

These are admirably adapted for covering walls, trellises, old trees, unsightly buildings, etc Their rapid growth, perfect hardiness, luxuriant foliage, immense clusters of beautifil flowars, conmend them at once to everyone.

Ibulthore Belle. Pale blusli, almost white; double; very beautiful; fragrant

flimbing Victor Terdier, Bright rose. (See II. P Roses) 
Julew Murgottln. See H. P. Roses;.

(iem of the l'ruirio. A hybrld between Madune Lafay and Quecut of the Frairic; bright red blotclsed with white: quite double, a frce hloomer and a good climber

Arevlllon Seven sisters. Purplish crimson and piuk; not quite liardy.

Pride of Wnshington. Brilliant amaranth, shaded rose center; large clusters, very double

Qneen of the Prairle. Iright rose color, large and double, very vigorous and rapid in its growth. the best climbing rose.

Sweet Briar. Rosy pink single flowers. followed in antunu by bright colored seed pods; foliage very fragrant.

\section{SUMMER ROSES.}

Ilarrison's Vellow. Double, bright yellow, very showy and finte

Iladame llarly. White, large, full and double.

Malame Plantler. One of the finest pure white roses, bloomiug in clusters.

Persian Vellow. Deep golden yellow, double and very fine.

\section{STANDARD AND HALF STANDARD, OR TREE ROSES.}

These are the roses of any of the previons sorts that are budded or grafted on the free or cul tivated stock of the Dog or Briar kose, from eigliteen incles to five feet from the ground, and form fine dwarf trees; and when properly cultivated and cared for make a very fine novelty, and should be in every well regulated lawn. Slıould be removed to the cellar, pit, or greenlouse dur. ing the winter.

\section{BOURBON ROSES.}

'These are not quite so hardy as the Hylorid Rose, requiring protection in the winter; they are coutinual bloomers, of vigorous rapid growth, with rich lux triant foliage.

Blauch Iaflte. Pale fleah color, full and beautiful.

Hermosa. Light blush or flesh color; large, full and double; grows freely and blorms profusely. Luis Ollier. Fiute bright rose, large full cupped form.

Lonis Ilargotfin. Delicate satin rose, fine form, free bloomer, and a siperb new rose.

Jrs. Panl. New; large open flower like Camelia, color blush white with rosy peach sluading, hloums in autumn.

Onecu of the Bourtous. Fawn colored rose, beautiful and profuse blonmer.

Gir.l. Paxton. Deep rose shaded with crimson; very strong grower; fine rich foliage and free bloomer.

Souventr de la Yuinou. Pale flesh with a fawn slade; very large, full, beautiful.

\section{NOISETTE, OR EVER-BLOOMING CIIMBERS.}

These are the finest autumnal blomers, and are distinguished by flowering in clusters They arc not quite hardy, requiring protection during the winter.

fugusta. Sulplur yellow, large and full, very fragrant, a strong grower, similar to if not ideutical with Solfaterre.

Caroline Mtriune. Creamy white, small and full, nearly lardy, flowers rescmble those of Felicite Perpetual.

Cloth of tioll (h, omatellu. Kich deep yellow, large, double, fragrant, and a vigorous grower.

Celine forestler. Fine bright yellow, highly fragrant, a strong grower and profuse lloomer, a fine rose.

l.cunrque. White, with sulphur center, flower in clustcrs; a magnificent climbing rose under grlass.

Laly Emily Peel. Ilas pure white flowers in large clusters, a free grower and fine for pillars.

llareclıl leil. Beautiful deep yellow, very large; full, globular form; suect scented, free floweting; one of the finest yellow 'Tea-scented kosen yet introduced; a good elimbing rose.

Madame Afferd de llunsenunt Hybrid Noisette. White, medium size, full.

Martha Washington. Pure white. very double; a vigorous grower and profuse bloomer 


\section{TEA ROSES, EVER BLOOMING.}

Tea Roses are celebrated for their delicious fragrance, the exquisite forms and rich charming tints of their flowers. They form thc largest and most popular section of the Ever Blooming Roses, producing an endless succession of flowers in a favorable climate, and even at the North blooming from the time thcy are planted until they are stopped by freezing wcather. Teas should be planted in a rich warm soil, where they will be kept constantly growing, for they bloom as they grow.

Bon Silene. Noted for the great size and beauty of its buds; color deep rose. This rose is used largely in floral work, and is highly esteemed for its rich dark color and beauty of form.

Catherine Ilermet. Bright flesh color, large, full, and of beautiful form; a fine winter bloomer in conservatories.

Duchesse de Brabant. Few roses equal this in freedom of flowering; none surpass it in either fragrance or vigor; color rose, heavily shaded $w \cdot i t h$ amber or salmon.

Duchesse of Elinburgh. A very desirable novelty; flowers of good size, moderately ful1, deep crimson in the buds, becoming brightcr as they expand; good for winter flowering.

Glorie of Dijon. Yellow shaded with salmon and rose; large, full, and distinct.

Iladame de Watteville. Also known as Tulip Rose on account of the beautiful feathery shadings of bright rose around the edge of each petal. A strong, vigorous grower, with handsome foli age. Color white, shaded with salmon; very fragrant; flowers large and beautiful shape.

Perle des Jardins. A beautiful straw color, sometimes deep canary; very large, full, and of fine form; stiff sloots or stems, and very free flowering.

Princess Beatrice. A magnificent yellow Tea Rose. The flowers, which are carried on long stiff stems, are of perfect form and a lovely shade of golden yellow, with a slight tint of pure rose.

Sanset. Large size, fine full form, very double, and deliciously perfumed. The color is a remarkable sliade of rich golden amber, elegantly tinged and shaded with dark ruddy copper.

Safrano. Bright apricot yellow, changing to orange and fawn, sometimes tinted with rose; valued lighly for its beautiful buds; fragrant.

Whe Bride. This is dccidedly the most bcautiful white Tea Rose. The flowers are very large and iuble, on long stiff stems, of fine texture and substance, and last a long time in a fresh state fter being cut, making it one of the best varieties for corsage wear or bouquets.

\section{PAEONIAS.}

\section{TREE AND HEBACEOUS.}

These are all slowy, beautiful flowers, perfectly hardy, easy to cultivate; Howering early in the season, before rose They deserve a place in every garden.

HERBACEOUS CHIXESE PEONHS. Angust Van Geert. Deep crimson, slightly tipped blush.

Delieatissima. Double, delicate rose, fragrant and fine.

Oflicinalis Malabilis. White, carmine center.

liosea Fragrans. Dcep rose, double, large and fragrant.

Striata Rosea. Blush white, large and full; insidc petals fringed and clonded with rose.

Victoria Tricolor. Outside petals pale rose, mottled with pink; center canary white; petals edged with red; a superb flower.

TREE PEONIA (Arborea). Very double, deep blush with purple center; showy and fragrant.

\section{CASSIA.}

Amerlcan Seuna (Marilonetica). A splendid herbaceous plant, three to four feet high; flowers pea shaped, bright yellow in anxiliary clusters; July and August.

\section{YUCCA, SPANISH BAYONET.}

These have a grand appearance; the stem is three feet above the ground, covered with large bell-shaped flowers on latcrals, forming a perfect pyramid.

Fllamentosa (Adam's Necdle). Thread leaved, creamy white, three to four feet; July. 


\section{MISCELLANEOUS BORDER AND HOUSE PLANTS.}

The following are the best varietles of these useful plants, which are exceedingly valuable on account of their liardiness, easy culture and slowy appearance. They will mostly live all winter in the open ground, and bloom freely every year. We name sonne leading sorts.

Bell blower (Campanula). Large showy bell-shaped flowers of pure white, blue, and purple; July and August.

Carnatlons. White, carmine, rosy pink, aud striped; very beautiful and fragrant, continuing in Alower a long time. Plant in pots in fall, and grow in conservatory or parlor window. One of the best louse plants.

Chrysauthemuns. The prettiest of late autumn and early flowering winter plunts. In November and Decenber there is nothing that will make such a cheerful display. Plant in pots and place them in the house where they will have the sun. The prevailing colors are white, yellow and red, the red being the lcast interesting.

Columbiue (Aquilegia. Well known, fowers hanging from rather small stems, abont two feet high; various colors.

Dleentra Spectabllis or Dlelytra Bleeding Heart. A beautiful hardy border plant, with brilliant rosy leart shaped flowers, hanging in great profusion fron a gracefully curved stem; May and June.

liollyhock. There are very few plants so grand and yet so perfect and delicate as the Hollyhock. Its flowers are quite as double and almost as pure a1:d perfect as thone of the camelia. Seeds sown in the spring produce plants that will bloom the second suminer. plants set out in the spring will flower about midsummer, and for several years, if not allowed to bloom too freely the first year.

lerennlal ilylox. The flowers of Perennial phlox are immense masses of bloom, from the purest white to crimson. They grow to a height of two feet or more and are perfectly hardy.

\section{SUMBLER AND AUTUMN FLOWERING BULBS,}

THAT REQUIRE TAKING IP IX THE F.IL, AND TO HE KLP'T FHOM FREEZING.

Houssingaultia Bassilloides'. Maderia Tine. An old wcll known climber, a rapid grower, with thick fleshy leaves and white flowers; grand for trailing in a porch.over a window, or in any place where you desire a beautiful green.

Dahlias Doublc. Well known autumn flowering plants, growing from two to five feet high, and producing a profusion of flowers of the most perfect and beatiful forms, varying in color from the purest white to the darkest maroon.

Gladlolus. Of all our smmer flowering bulbs the Gladiolus stands eminenty at the head as the most varied and beatiful class. The flowers are produced in spikes two feet in lieight and upwards; the brilliant scarlet and crimson of some, form a striking contrast with the delicate shades and pencilings of the lighter colored varleties. By planting at intervals from May first to middle of June a snccession of flowers can be hat from July to Uctober.

Tuberose Double and single. Flowers very fragrant; flower stems from three to four feet; autuun.

PEARL. Its valuc over the cominon varicty consists in its flowers being uearly donble in size; imbricated like a rose, and in its dwasf halit growing only eighteen inches to two feet. The fragrance and color same as common sort.

Tlgridas shell Flower. One of our favorite summer flowering bulth, of the easiest culture, displayng their georgeous tulip like flowers of orange and scarlet daily form July to uctober.

\section{FLOWERING BULBS.}

Irveus. In various colots.

TO HF: ILLATYID I.Y THF FAL.。

frltillaria Imperiuliv Crown Imperial. Very showy plants, are quile hardy, and when the bulbs are once planted they need no firtherculture. Plant five inches deep, one fout, apart 
Suowdrop. This, the earliest of spring flowering bulbs, is universally admired for its elegant snow white drooping blossoms.

Hyacinths. Among all the bulbs used for winter flowers the Hyacinth stands foremost on the list. Two methods are employed in flowering the Hyacinth in winter, one in glasses filled with water, the other in pots or boxes of soil.

Jonquils. Pretty varietics of the Narcissus, having a very agreeable fragrance; adapted to eitlier pot or out-door culture, the bulbs being small six or eiglit may be put in a six incli pot.

LLIUM LILY. The Litiums are entirely hardy, and with few exceptions quite fragrant, and most of the varieties are exceedingly beautiful.

Auratum. Gold Banded Lily. A magnificent Japan lily

Caudidum. Common White.

Lancifolium Album. White Japan; spotted, iragrant.

Lancifollum Roseum. Rose spotted with crimson.

Lancifolium Rubrum. Red spotted.

Tigrinum. fl pl Double Tiger Lily. Bright orange scarlet with dark spots.

Lancifolinm l'uuctatum. White and pink.

Iarrish. (The Bermuda Easter L,ily)-The flowers are large, trumpet shaped, pure waxy white, gracefully formed and delightfully fragrant. The ease with which it can be forced into flower in winter has made it wonderfully popular as a winter flower. It is grown extensively for church decorations at Easter.

Lily of the Valley. The Lily of the Valley is as hardy as any plant can possibly be, aud when planted in the open ground will increase pretty rapidly.

Narcissus. Garden varieties. Admitably adapted for garden decoration in early spriug. They are easily cultivated; hardy; very showy and fragrant.

Tulips. Owing to late spring frosts, bedding plants cannot safely be planted before the early spring flowering bulbs are through blooming. Without tlicse bulbs, for one or two months of beautiful spring weather, our gardens would present a bare appearance. Nothing for the amount of money invested will give a nore gorgeons show during carly spring, and there is nothing more easily grown than the Tulip. They thrive well in almost any soil; should be planted during October and November.

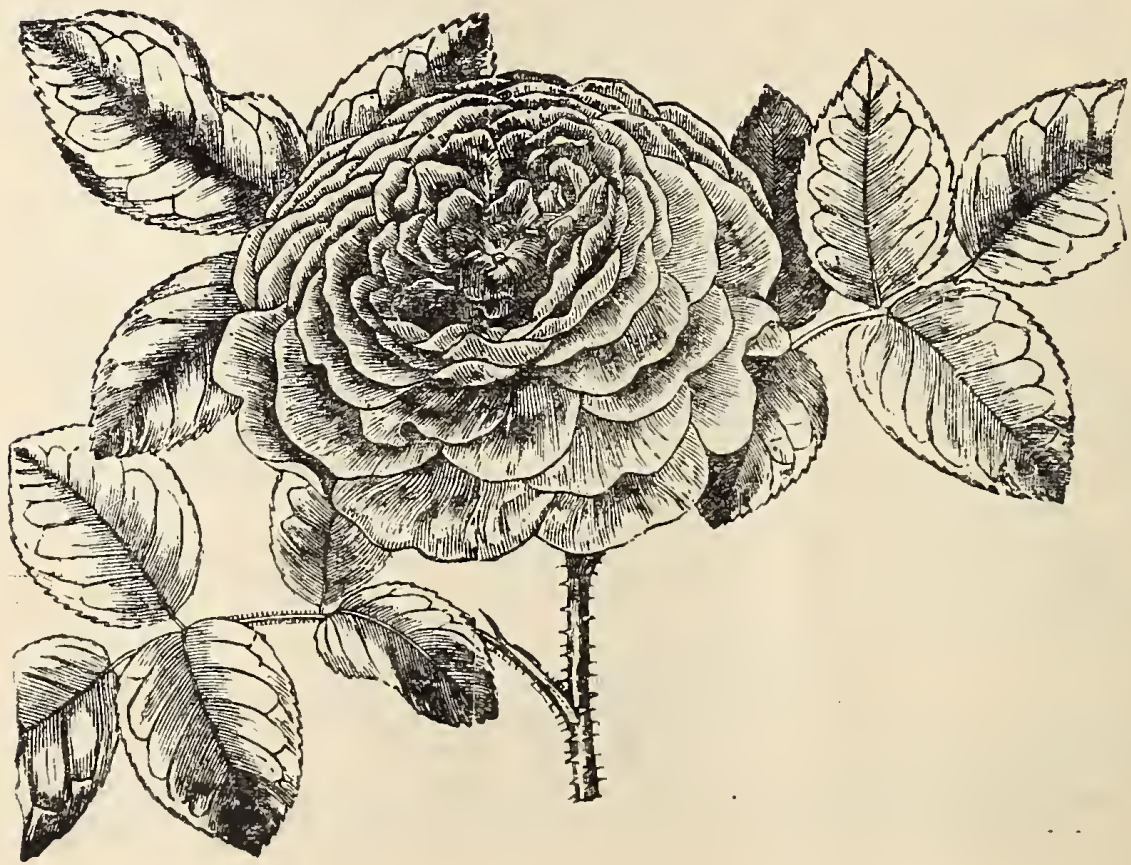




\section{SPRAXING.}

Experience has demonstrated the fact, that Spraying at the proper time and properly done for the protection against destructive insects, rot, tungus and blight is the best if not the only sure remedy agaiust these enemies of the horticulturalist, and that it has succeeded and will suc. cecd is evidenced by the rapidly increasing interest manifested in the manufacture, sale and use of spraying machimes, and the good results obtained by those who have practiced this mode of protection.

\section{WHEN TO SPRAY.}

Apple Trees. For prevention of leaf blight spray as soon as the leaves are full grown with Bordeaux mixture or ammoniacal carbonate of copper. To destroy the aphis or plant lice, spray with kerosene emulsion as soou as the pests appear. To destroy the codling moth, canker worm A ud curculio, spray with Paris green or London purple, $1 / 4$ pound in 40 or 50 gallons of water, soon after the blossoms fall, and again in two weeks later. To destroy the web worm, spray with London purple or kerosene enulsion about August 1st to 10th, or as soon as they appear. This application should be made during the middle of the day, when the worms are out of their webs and feediug on the lcarcs.

Cherrles. Treatmont same as recommended for the apple.

Penrs. The pear slug cau easily be destroyed by spraying with Paris green four ounces to 50 gallons of watcr, or kerosene emulsion as sooll as it begins operations. Pear and quince blight can be destroyed by spraying with Bordeaux mixture. The codling moth and curcnlio should be treated same as rccolumended for apple trecs.

Plums. Destroy the aphis with keroscne emulsion and a fine spray nozzle. The curculio cals be destroyed by spraying with 3 oz. Paris greeu to 40 gallous of water. First application should be made as soon as blossoms have fallen, and repeated at intervales of a week or ten days. Four applications slould be sufficient. Other enemies of the plum will be destroyed by thin wethod, but in all cases be particular to keep the poison and water coustantly stirred.

Praches. If attacked by the black peach aphis, spray with kerosene eluulsion. Tlie plum curculto frequently attack the peacl, in which case spray with Paris grecn, two cunces to 50 gal. lons of water; be sure to keep it well stirred, and use witl cantion. Never nse London purple on peach trees.

Grape Rot and Mildew use the Bordeaux Mixture.

Currants and (iooseberrles. To destroy the worus, spray with powdcred white hellebore, oue ounce in three gallons of water, as soon as the worms appear. To dcstroy the yellow aphis, spray with kerosene enulsion early in the season. To preveut mildew, nse one-lialf onnce potassium sulphide to one gallon of water.

\section{FORMULAS.}

Keruseno Emulsion. In makiug the kerosene emulsion for spraying trees for lice, be sure and follow the correct method: Dissolve in two guarts of water one quart of soft soap or 3 , pound of hard soap by heating to the boiling point. Then add one pint of keroseue oil and stir violently for from three to five minutes. This may be done by using a common force pumpand putting the end of the hose back into the mixture again. This mixes the oil peruaneutly;, so that it will uever separate, and it may be diluted easily at pleasure. This mixture should be diluted to twice ita bulk with water or about 14 tincs as much watcr as keroseue. The kerosene emulsion is successful in destroying cattle lice and shcep ticks, as well as all varieties of plaut lice.

Bordeaux Yixture. Six pounds of sulphate of copper are dissolved in six gallons of water; in another vesscl four pounds of fresll lime are slacked in six gallons of water. Aftcr the latter soln. tion has cooled, slowly turn it iuto the other solution and add ten gallons of water. This, wheu all is thoroughly mixed and strained, is ready for use. In straining this mixture reject all of the line sediment, using only the clear liquid; strain the whitewash through a coarse gunny sack stretched over the liead of a barrel.

\section{TREATMENT OF BLACK ROT AND MILDEW OF THE GRAPA, PEAR SCAB AND LEAF BLIGHT.}

Hordmanx Vixture. I loimsolve 1f, ponmls of anlplate of copper in an gallons of water in auother vessel slack 30 pounds of lime in 6 gallous of water When the last mixture has copled 
pour it slowly into the copper solution . taking care to mix the fiuids thoroughly by constant stiring. It is well to have this compound prepared some days before it is required for use. It should be well stirred before applying.

A solution containing the ingredients in the following proportions has been recommended for general use:

Bordeanx Mixture. (B) Dissolve six pounds of copper in 16 gallons of water, and slack four pounds of fresh lime in six gallons of water. When cool mix the solution as described above.

Solution of Inmoniacal Carbonate of Copper. Into a ressel having a capacity of about one gallon, pout one quart of ammonia (strength 20 degrees Baume; add three ounces of carbonate of copper; stir rapidly for a moment and the carbonate of copper will dissolve in the ammonia, formIng a very clear liquid. For use dilute to 25 gallons.

Ean Celeste, Modifled Formnla. Dissolve four pounds of copper sulphate in ten or twelve gallons of water. Add three pints of strong ammonia, dilute to 50 gallons, and add five pounds of common washing soda. Stir thoroughly and the solution is ready for use. This may be used in place of the mixture mentioned above, but no special advantage is claimed for it over the other

The Cornell University, College of Agriculture, Ithica, N. Y., recommends carbonate of copper for grape diseases instead of Bordeaux mixture, because it is much more easy to prepare and handle, and it is also cheaper. There are two or three good formulas: Dissolve three ounces of carbonate in a quart of ammonia and dilute to 25 gallons. Another good formula is fire ounces of carbonate in three pints of strongest ammonia, and dilute to 50 gallous.

(From the Journal of Mycology, Washington, D. C., 1891.)

* * The cheapest and most effectual remedy for black rot and downy mildew, taking ererything into consideration, is the ammoniacal solution of copper carbonate. Next to this, a mixed treatment consisting of two or three early sprayings of Bordeaux mixture and the same number of late treatments with ammoniacal solution.

Yo Danger Whaterer. Not only hundreds, but thou sands of tons of mineral poisons have been employed during the past decade by farmers throughout the country, whether to protect the potato crop, or the cotton crop, or other products of the soil from the ruinous attacks of insects. The general experience during this long period and over the whole country is so emphatically in faror of their use, and their perfect safety and harmlessness, with ordinary precautions, as to reader almost laughable the objections of the few persons who object to them. No advancement, no improvement, no general benefit to the human race is ever accomplished without some attendant danger, and those who inveigh against such improvements as increasing the risks of life stand on the same footing as the cpponents to arsenical poisons as insecticides. Report of the United States Entomological Commissiou.

(New York Weekly Tribune, Nov. 4, 1891, by Professor A. J. Cook.)

Lime with the Irsenites. Use of the ansenites, L,ondon purple and Paris green, to protect apples is becoming very common. We should nerer use these poisous strouger than one pound to 200 gallous of water; that strength is always sufficient to accomplish the purpose. If weaker than this, we do not always reap full benefit. Last year Professor Gillette found that by the use of lime with these substances the soluble arsenic was changed into an invaluable compound, and then the follage was not injured. The same has been proved true at the Michigan statiou. We cxperimented on all our fruit trees, even the tender peach, and the lime in evcry case prevented all injury. We tried several applications at intervals of ten days on some plauts, and no harn resulted. We see then, that by use of Bordeaux mixture or limewater instead of pure water, we can entirely prevent injury to foliage by the arsenites. The limewater should be formed by putting from 1 to 4 pounds of thoroughly slaked lime into 100 gallons of water. If we wish to use an insecticide and a fungicide at the same timc, then we may add 1 pound of London purple to 101 gallons of Bordeaux mixture. In every case the lime must be carefully and thoroughly soaked, or that will kill the foliage. 


\section{GENERAL INDEX.}

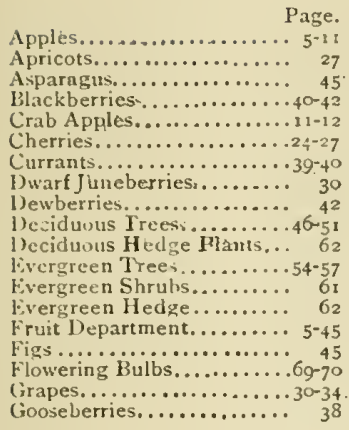

Hop Vine................... Page. .... 30 Hardy Climbing and Trail

ing Shrubs..............62-64 Herbaceous Pronias........ 68 Introductory.

List of Trees and Slurubs for

Special Purposes.........

Mulberries............... 29

Miscellaneous border and

House I'lants............

Nectarines...................

Nuts................... 30

Oruanental Department... 46

Ornamental'Shrubs........ 57-6r

Pears.....................12-16

Peaches.................16-20

Plums. ..................20 24

Plums $\{$ Native $) .. . \ldots \ldots \ldots \ldots .22-23$
Plums (Japan Var.)....... Page.

Quinces..................28 $282^{2}$

Remarks....................

Rhubarb.................. 45

Roses (H. P.) .............65 656

Roses (Climbing) .........66-67

Roses (Hybrid Tiea)....... 66

Roses (Moss)............... 66

Roses (Summer) ............. 67

Roses (Tree) i............... $6_{7}$

Roses (Bourbion).............. 67

Roses (Nóisette\}.......... 67

Roses (Tea) ............ 68

Raspberries................ 34-37

Strawberries............... ${ }^{2-44}$

Scions and Buds............ 30

Summer and Autumn. Flow.

ering: Bulbs............ 6

Weeping Decid's Trees....5

\section{INDEX \\ TO ORNAMENTAL.TREES, SHRUBS, ETC.}

Ailantus ............... Abies................. 57 Acer... ...............49-50 Akebia.................... Akebia........................ ${ }_{4}^{6}$ Althea............... 57 Almond................4 6-57 Ampelopsis............. 62 An emone.............. 57 Arbor Vita............ 54-55, 62 Aristolochia.............. 63 Ash ................. 47.51 Azalia $\ldots \ldots \ldots \ldots \ldots \ldots \ldots . . .6 \%$ Beech.................. ${ }^{57}$ Berberry ............... 57-58 Retula.................47, 52 Bignonia............... 63 Birch................47, 52 Bittersweet............... $66_{3}$ Bleeding. Heart.......... 69 Box...................6r $66^{62}$ Buckthorn............ 57 Calycanthus ............ ${ }_{58}^{8}$ Catalpa................ ${ }_{68}^{47}$ Cassia.......................... 68 Cedar, Red................. ${ }_{5}^{6}$ Chestnut............... 47

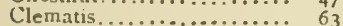
Cornus................. $48,52,59$ Currant................. 58 Cypress.................... 47-56 Dahlia................ 69 Daphne:.................. $5^{8}$ Deutzia.................. $5^{8-59}$ Dogwood.............48,52. 59 Elm.......................48. 52 Elxagnus............. 59 Elder.......... ..... 59

Eironymus .................. 59 Fagus................. Fir......................
Forsythia........... 59 Fraxinus............... 47 , 5 Fringe, Purple........... 59 Fringe, White........... 6 I Gladioli................... $6_{9}$ Halesia............... 59 Hemlock.............. .57, 62

Hibiscus................. 57

Honeysuckle............59, 63-64

Honeysuckle.......... 59, 63-64

Hornbeam $\ldots \ldots \ldots \ldots \ldots \ldots$
Horse Chestnut.......... $4^{8}$

Hydrangea. ............. 59

Holly................ 6

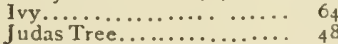

Jessamine............... 59

Juniper.................. 56

Kentucky Coffee........ 48

Kerria............... 50

Kolreuteria.............. $4^{8}$

Laburnum .............. 49

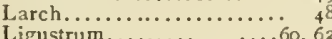

Ligustrum...................

Lily..................

Lily of the valley..........

Linden..................49, 53

Liquidambar............ 49

Liriodendron............ 5

Locust................... 49

Lonicera.............59, 63-64

Magnolia............... 49

Mahonia................ 61

Maple..................49-5

Maiden Hair. Tree......... 5

Morus..................... 50,54

Mountain Ash.............. 50, 53

Mulberry................50, 54

Olive............... 51

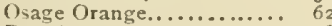

Pronias.................... 68

Peach....................

Persimmons.............
Picea................ ${ }_{56}$

Pine.................. $5^{6}$

Plum................... 5r, 59

Poplar............... 51, 54

Privet.............., 60,62

Quince, Japan............60, 62

Red Bud.............. 48

Retinospora.............. 56

Rhododendron........... $6 \mathrm{I}$

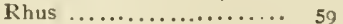

Ribes................ 58

Rose of Sharon .......... 57

Salisburia............. 5

Silver Bell............. 59

Smoke Tree........... 59

snowball.............. 6r

Snowberry................. 60

Sorbus................ 50

Silk Vine ............. 64

Spiraxa ... .......... 60

Spruce.................. 57,62

Strawberry Tree........... 59

Sweet Gum Tree......... . 49

Sweet Scented Shrub....... $5^{8}$

Sycamore $\quad \ldots \ldots \ldots \ldots \ldots .66^{5}{ }^{5} \mathrm{I}$

Tartarian Honeysuckle... . 59

Tamarix. . ........... 6 6

Taxus................. 57

Thorn.............. 51

Thuja .............. $54-55$

Tilia................ 49,53

Trumpet Flower............. 63

Tulip Tree... ......... $5^{\mathrm{I}}$

Tuberose . .......... 69

Vibunnum............... $\sigma_{1}$

Virginia Creeper .......... $6_{3}$

Walnut $\ldots \ldots \ldots \ldots \ldots \ldots . \quad 3^{\circ}$

Willows ............... 5 I

Willow Weeping............ 54

Wistaria $\ldots \ldots \ldots \ldots \ldots \ldots .66_{4}$

Yellow Wood.............. 5 t

Yew. ................ 57 
The Hart Pioneer Nurseries, Descriptive Catalogue.

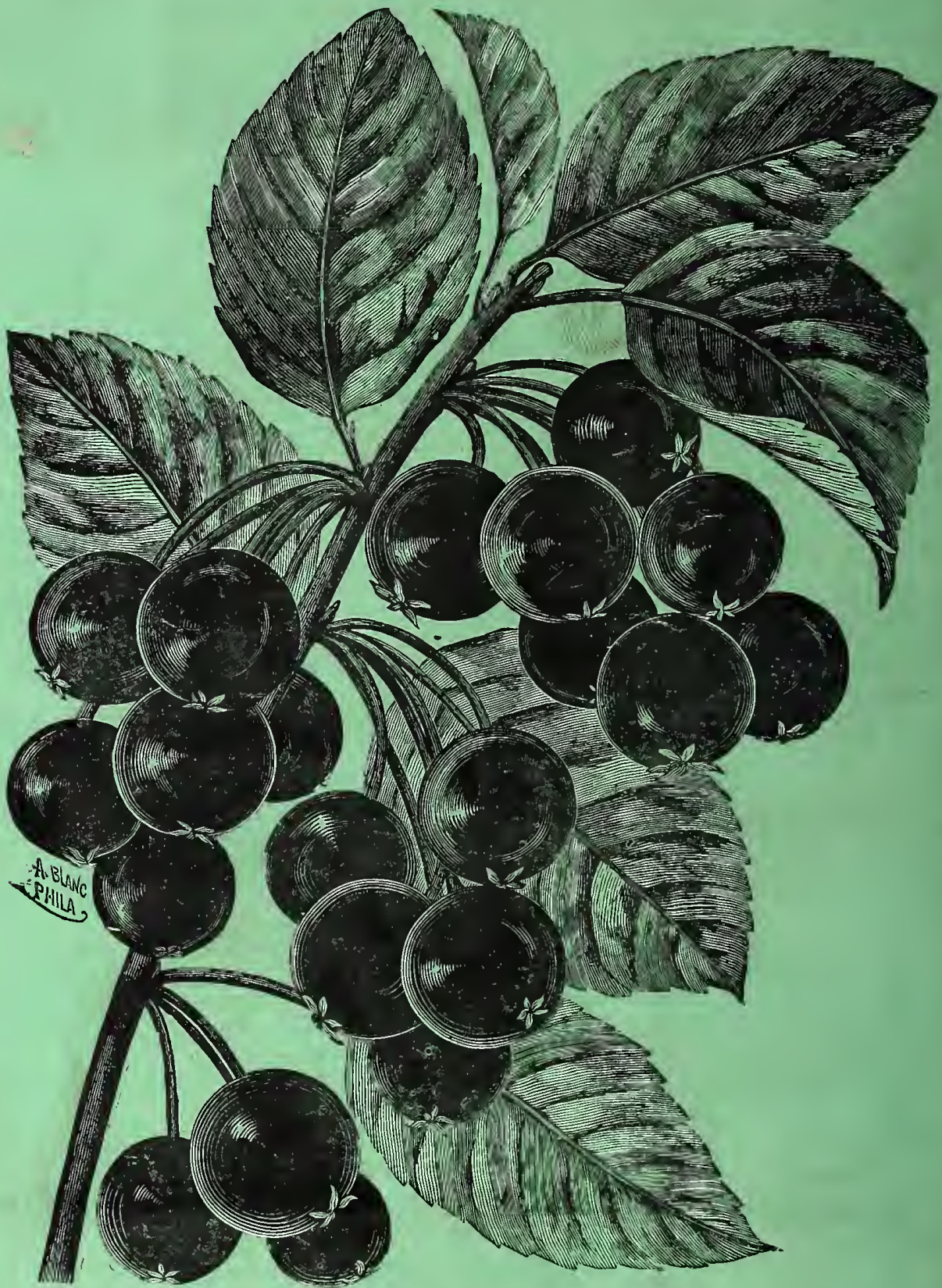

THE "KANSAS BEAUTY HUCKLEBERRY."

A rare and extremely valuable addition to the small fruits, hardy, productive and beautiful. The following description of this fruit by Hon. M. E. Hudson, deceased, Past Master of the Kansas State Grange, on whose farm it was first propagated 1 this section and tested, will be read with interest. The reputat on of Mr. Hudson being an ample guarantee to all who know of him that the statement; therein contained are true:

"I have cultivated this berry in Kansas for lourteen years, and can unhesitutingly recommend it as a valuable and delicious fruit, easy to cultivate, very thrifty grower, hardy and a profuse bearer. Jrouth or cold uwinters do not affect it, and his never been injured by gubs, borers or any destructive insects. They commence bearing the second or third year after setting. and have never failed to bear a single vear since. My first setting, now fourteen years growth, will sield at leilst fourgallons to the bush lingrou th they resemble the currant but grow much taller. I have them now seven feet high, and at least four feet wide across the trip of the buh.

The bush is smooth and entirely free loom thorns or briers, as is aliso the fruit. 'The berry ripens in June, or about the time that cherries do. When ripe they are alout the size and shape of the cranberry, but of a dark purple color. They are siveet, and hence require but litt!e sugar in preparing tirem for the tahle. In picking, the stem is left on the bush, and a small hisky seale on the bottom end is all that has to be taken off in preparing them for use. Wherever this frut is introduced it will give satisfaction. Every falmer should have it. l regard it as one of our best small fruits.

M. E. HUDSON."

THE HART PIONEER NURSERIES, - FORT SCOTT, KAN. 